\author{
UNIVERSIDADE DE SÃO PAULO \\ FACULDADE DE ECONOMIA, ADMINISTRAÇÃO E CONTABILIDADE \\ DEPARTAMENTO DE ECONOMIA \\ PROGRAMA DE PÓS-GRADUAÇÃO EM ECONOMIA
}

TRÊS ENSAIOS SOBRE ECONOMIA INTERNACIONAL

Mirela Virgínia Perrella Scarabel

Orientador: Prof. Dr. Mauro Rodrigues Júnior

SÃO PAULO 
Prof. Dr. Marco Antonio Zago

Reitor da Universidade de São Paulo

Prof. Dr. Adalberto Américo Fishmann

Diretor da Faculdade de Economia, Administração e Contabilidade

Prof. Dr. Hélio Nogueira da Cruz

Chefe do Departamento de Economia

Prof. Dr. Márcio Issao Nakane

Coordenador do Programa de Pós-Graduação em Economia 
Mirela Virgínia Perrella Scarabel

\section{TRÊS ENSAIOS SOBRE ECONOMIA INTERNACIONAL}

Tese apresentada ao Programa de PósGraduação em Economia do Departamento de Economia da Faculdade de Economia, Administração e Contabilidade da Universidade de São Paulo, como requisito parcial para a obtenção do título de Doutor em Ciências.

Orientador: Prof. Dr. Mauro Rodrigues Júnior

Versão original

SÃO PAULO

2017 
FICHA CATALOGRÁFICA

Elaborada pela Seção de Processamento Técnico do SBD/FEA/USP

Scarabel, Mirela Virgínia Perrella.

Três ensaios sobre economia internacional / Mirela Virgínia Perrella Scarabel. -- São Paulo, 2017.

$112 \mathrm{p}$.

Tese (Doutorado) - Universidade de São Paulo, 2017.

Orientador: Mauro Rodrigues Júnior.

1. Economia internacional. 2. Finanças internacionais. 3. Comércio exterior. I. Universidade de São Paulo. Faculdade de Economia, Administração e Contabilidade. II. Título.

CDD - 337 
À MINHA FAMÍLIA 



\section{AGRADECIMENTOS}

Acredito que todas as pessoas que passaram pela minha vida contribuíram de alguma forma para minha formação pessoal e profissional e, consequentemente, para este trabalho. Sou muito grata a todas elas.

Em especial, agradeço à minha família que sempre me apoiou em todas minhas decisões, que sempre me incentivou a batalhar pelo que se deseja e valorizar o conhecimento.

Ao meu orientador, Prof. Dr. Mauro Rodrigues Junior, pelo apoio, pela compreensão, pelas sugestões sempre pertinentes e por todo conhecimento transmitido.

Ao Prof. Dr. Naercio Aquino Menezes Filho que foi como um segundo orientador para mim, se mostrando totalmente disponível e fazendo apontamentos sempre de grande valor.

Ao Prof. Dr. Fábio Adriano Miessi Sanches que também se mostrou muito disposto a ajudar e deu contribuições essenciais ao capítulo 2 desta tese.

Ao Prof. Dr. Marcos Nakaguma, o qual participou do meu exame de qualificação e deu importantes contribuições bem como aos professores que aceitaram fazer parte da banca de defesa da presente tese.

Ao Prof. Dr. Marc Muendler da University of California, San Diego (UCSD) que aceitou me receber como Visiting Scholar e, ainda, me deu a oportunidade de ser sua research assistance.

Aos demais docentes do Programa de Pós-Graduação em Economia e, em especial, aos funcionários da FEA Pinho, Leka e Cida, que foram fundamentais para me manter motivada no curso.

Agradeço, ainda, aos meus colegas de curso, aos meus amigos e aos meus ex-colegas de trabalho; principalmente, ao Fernando Honorato Barbosa por ter me concedido a oportunidade de continuar trabalhando enquanto fazia este curso. Também a Fundação Instituto de Pesquisas Econômicas (FIPE) pelos oito meses de bolsa-auxílio.

A todos vocês, meus sinceros agradecimentos. 



\section{RESUMO}

SCARABEL, Mirela Virginia Perrella. Três ensaios sobre economia internacional. 2017. 114f. Tese (Doutorado) - Faculdade de Economia, Administração e Contabilidade, Universidade de São Paulo, São Paulo, 2017.

O presente trabalho teve por objetivo avaliar aspectos relevantes da economia internacional. O primeiro ensaio desta tese visou avaliar pela primeira vez (até onde se tem conhecimento) se o recente desenvolvimento do mercado de Credit Default Swaps - CDS alterou os efeitos das mudanças de rating sobre o mercado financeiro. Como o CDS é um derivativo que tem como objetivo refletir a qualidade do crédito do ativo avaliado e esta mensuração é feita através do mercado e de forma contínua no tempo, este instrumento poderia reduzir a relevância dos ratings atribuídos pelas agências; uma vez que estes últimos também avaliam a qualidade do crédito, mas sua atuação é discreta no tempo. Foi empregada a metodologia de estudo de evento a uma base de dados diária de CDS, bolsa e taxas de câmbio para 37 países. Em resumo, foram encontradas evidências de que o impacto das mudanças de ratings sobre os ativos financeiros sofreu moderação nos últimos dez anos e que o papel do CDS pode estar por trás desta redução. Além disso, foram encontrados resultados que mostram que o mercado de CDS é o que mais reage a reclassificações de risco. O principal objetivo dos ensaios seguintes é trazer luz ao debate das fontes de competitividade no comércio internacional. Neste sentido, o segundo ensaio trata do papel do custo fixo de entrada para a exportação sobre a competitividade internacional no nível da firma. Foi estimado o custo médio de entrada para a exportação utilizando o banco de dados do World Bank Enterprise Survey do Banco Mundial que conta com informações de mais de 70 mil firmas de diversos setores de atividade distribuídas em mais de 120 países em desenvolvimento. A pesquisadora se apoiou no modelo e na metodologia desenvolvidos na publicação da Econometrica de Das, Roberts e Tybout (2007) e conclui que em média uma firma paga 3,2 milhões de dólares para começar a exportar. Além disso, encontrou que o custo fixo de entrada para exportação varia entre os países e isso ajuda a explicar porque firmas semelhantes com produtividade parecida instaladas em países diferentes têm probabilidades distintas de serem exportadoras. No terceiro ensaio desta tese, estudou-se o impacto da desoneração da folha de pagamento, implementada a partir de 2011, nas exportações e importações brasileiras. Através de um painel de efeito fixo para produto, relacionando as exportações e importações em função da variável desoneração e a da variável de intensidade de mão-de-obra na produção do bem. Os dados foram extraídos do MDIC, da PIA e a variável desoneração foi construída utilizando as diversas leis que, ao longo do tempo, foram ampliando o rol de bens desonerados. Grosso modo, controlando por intensidade de mão-de-obra, encontrou-se que as desonerações foram responsáveis por uma queda da quantidade importada dos bens cujos similares foram desonerados internamente, enquanto que o efeito nas exportações provocou uma queda nos preços dos bens desonerados que não foi compensada por uma elevação na quantidade exportada, o que conjuntamente resultou em uma queda das exportações em valor.

Palavras-chave: Comércio internacional. Desoneração da folha de pagamento. Custos de entrada. Competitividade. Instituições. Agência de risco. Ratings. CDS. 



\begin{abstract}
SCARABEL, Mirela Virginia Perrella. Three essays on international economics. 2017. 114f. Tese (Doutorado) - Faculdade de Economia, Administração e Contabilidade, Universidade de São Paulo, São Paulo, 2017.

This thesis evaluated some relevant aspects of the international economy. The first chapter evaluates for the first time (as far as we know) if the recent development of the credit default swaps market, CDS, has changed the effects of rating reclassifications on the financial market. Given that the price of CDS is driven by the entity's credit quality and it moves continuously over time, this instrument would reduce the significance of ratings assigned by the agencies, since these agencies act discretely over time. We apply the event study methodology to a daily database of CDS, stocks and exchange rates for 37 countries. Generally speaking, we find evidences that the impact of ratings changes on financial assets has moderated over the past decade and that the role of CDS may explain this reduction. Furthermore, we find results that show that the CDS market is more responsive to risk reclassification.

The following chapters have the main objective to shed some light on the debate on the sources of competitiveness in international trade. In this sense, the second chapter studies the role of sunk entry cost to export in international competitiveness at firm level. We estimate the average export sunk entry cost using the World Bank Enterprise Survey database of the World Bank that has informations about more than 70 thousand firms spreaded over several activity's sectors and more than 120 developing countries. We followed the model and methodology developed by Das, Roberts and Tybout in a paper published in Econometrica in 2007 and we found that a firm, in average, pays 2.3 million dollars in order to start exporting. Besides that, we found that the export entry cost varies between countries and this fact helps to explain why similar firms in different countries have different probabilities to become exporters.

In the third chapter of this thesis, we present a study on the impact of the payroll tax exemption implemented since 2011 on Brazilian exports and imports. Using a panel of fixed effect for product, we will relate the exports and imports as function of the variable exemption and the variable of labor intensity in the production function of the good. The data were extracted from the MDIC, the PIA and the variable exemption was constructed using the many laws that, over time, were expanding the list of exempted goods. Generally speaking, controlling by labor intensity, we found that the payroll tax exemption was responsible for a drop in the quantity of goods imported from abroad, while the effect on exports led to a drop in the prices of the goods exported, which was not offset by a rise in the quantity exported, resulting in a fall in exports by $F O B$ value.
\end{abstract}

Keyword: International trade. Payroll tax exemption. Entry costs. Competitiveness. Institutions. Credit rating agency. Ratings. CDS. 



\section{LISTA DE TABELAS}

Tabela 1 - Início dos dados por ativo e país 21

Tabela 2 - Distribuição dos eventos por tipo de evento e período 23

Tabela 3 - Distribuição dos eventos por país e período. 24

Tabela 4 - Estatística descritiva de $\mathrm{CR}(0,+1)$ condicionada à ocorrência de evento positivo e negativo

Tabela 5 - Estatística descritiva de $\mathrm{CR}(-30,-1)$ condicionada à ocorrência de evento positivo e

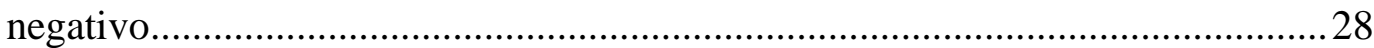

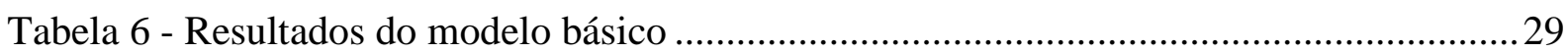

Tabela 7 - Comparação da reação entre antes e depois de 01/01/2005 ................................... 31

Tabela 8 - Resultados do modelo básico para a amostra após 01/01/2005 ............................. 32

Tabela 9 - Resultados do modelo utilizando o CDS como variável de controle ...................... 34

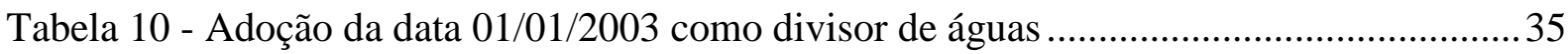

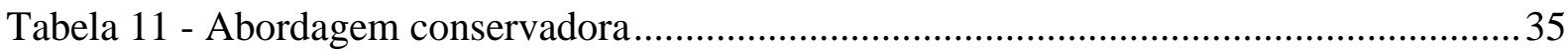

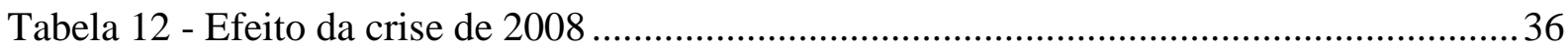

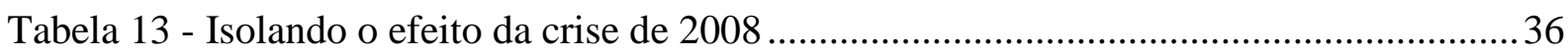

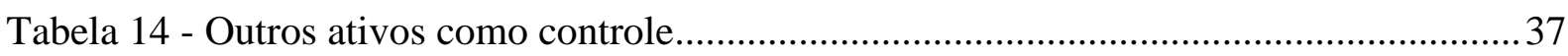

Tabela 15 - Mudança na classificação de investment grade.................................................... 38

Tabela 16 - Mudança na classificação de investment grade controlando pelo CDS .................39

Tabela 17 - Comportamento das firmas sobre a atividade exportadora .................................54

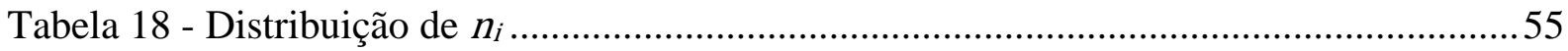

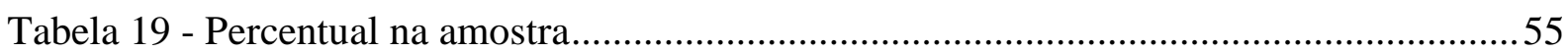

Tabela 20 - Estatística descritiva das demais variáveis ..........................................................56

Tabela 21 - Média das variáveis dada a classificação da firma ..............................................56

Tabela 22 - Percentual das respostas dadas pelas firmas aos problemas institucionais ...........57

Tabela 23 - Modelo Probit sobre a decisão de exportar ............................................................58

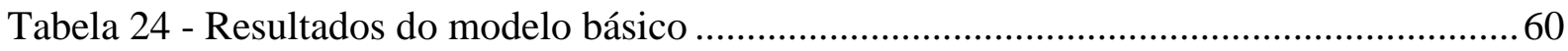

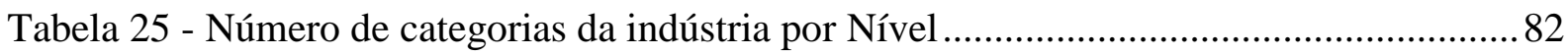

Tabela 26 - Quantidade de produtos desonerados ao longo do tempo .................................... 83

Tabela 27 - Impacto das desonerações sobre exportação e importação ................................... 90

Tabela 28 - Impacto das desonerações controlando por intensidade do uso de mão-de-obra.. 91

Tabela 29 - Impacto das desonerações sobre exportações com outras variáveis de fator trabalho 
Tabela 30 - Impacto das desonerações sobre importações com outras variáveis de fator

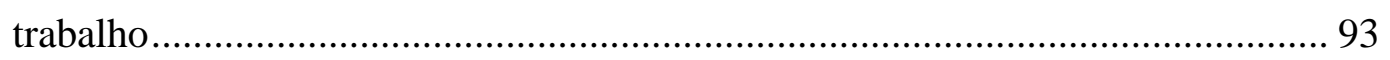

Tabela 31 - Impacto das desonerações em momentos distintos.......................................... 95 


\section{LISTA DE FIGURAS}

Figura 1 - Estoque total de Credit Default Swaps (trilhões de dólares)

Figura 2 - Custo fixo de entrada para a exportação em cada país em relação ao custo de outro país 63

Figura 3 - Probabilidade de exportação no país em função do CFE 65

Figura 4 - CFE e a qualidade das leis aduaneiras 66

Figura 5 - CFE e a concorrência com setor informal 67

Figura 6 - CFE e a dificuldade de se conseguir um alvará 67

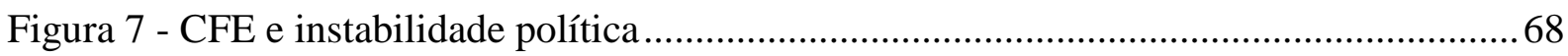

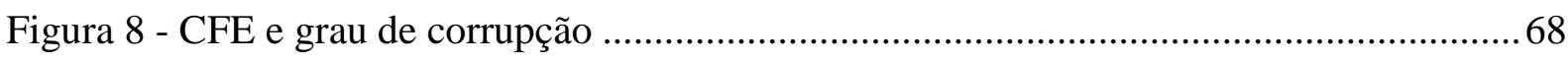

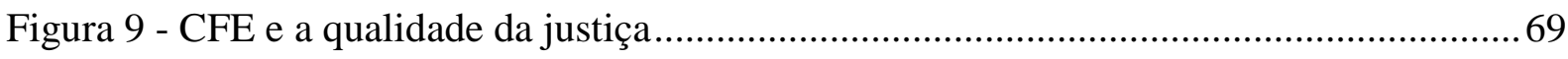

Figura 10 - CFE e a qualidade das leis trabalhistas.... 69

Figura 11 - Diferencial de crescimento das Exportações Brasileiras (média de 2012 a 2014 média de 2009 a 2011). 86

Figura 12 - Diferencial de crescimento das Importações Brasileiras (média de 2012 a 2014 -

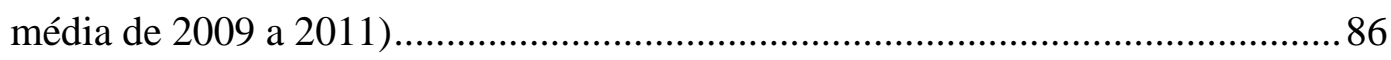

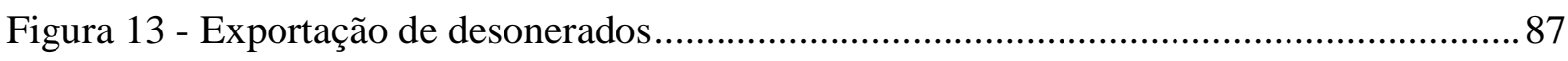

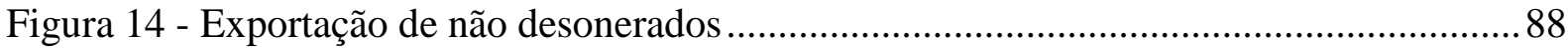

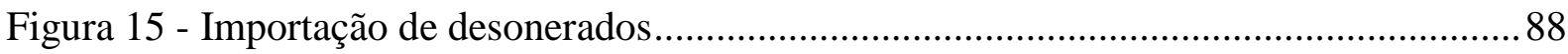

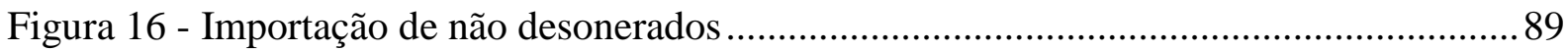





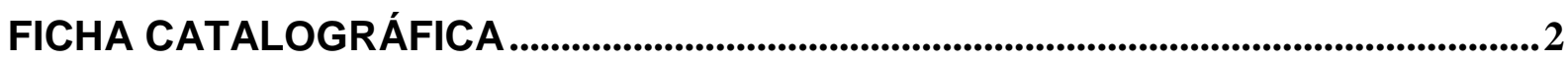

1 A DISSEMINAÇÃO DOS CREDIT DEFAULT SWAPS ALTEROU A RELAÇÃO DAS AGÊNCIAS DE RISCO COM O MERCADO FINANCEIRO?

1.1 INTRODUÇAี

1.2 .1 Países

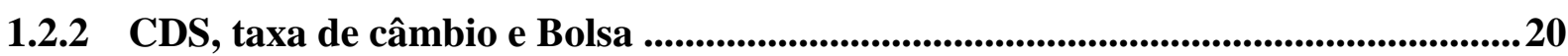

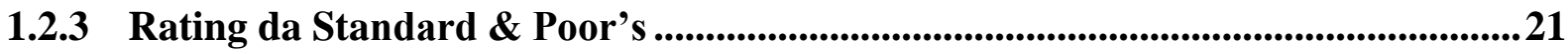

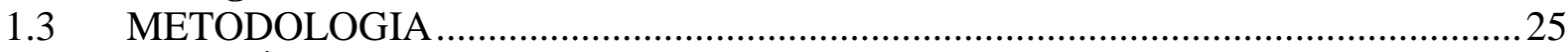

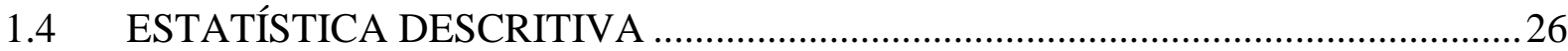

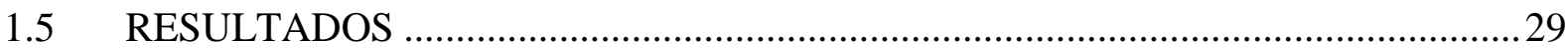

1.5.1 Modelo básico .....................................................................................................29

1.5.2 Separação da amostra entre antes e depois do boom do mercado de CDS ............30

1.5.3 Estimações utilizando o CDS como controle ........................................................33

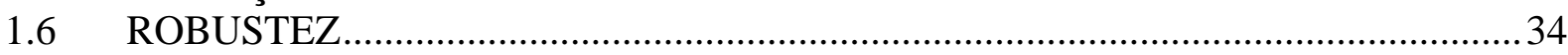

1.6.1 Escolha do período de boom do mercado de CDS ................................................34

1.6.2 Outros ativos como controle ..............................................................................36

1.6.3 Separação entre investment grade e não investment grade ..................................37

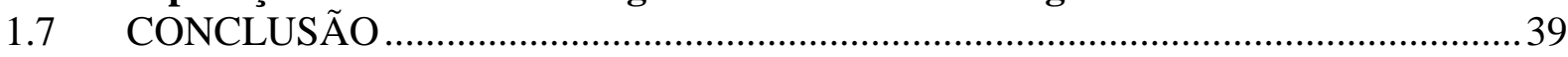

2 CUSTOS DE ENTRADA PARA EXPORTAÇÃO COMO FONTE DE COMPETITIVIDADE. ..........................................................................................41

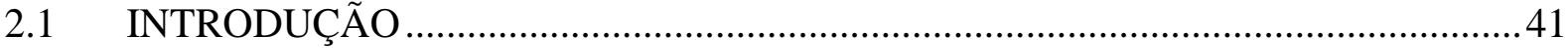

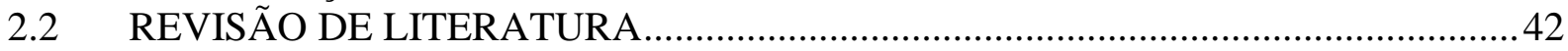

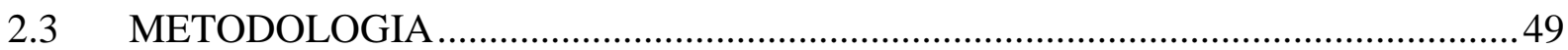

2.4 DADOS

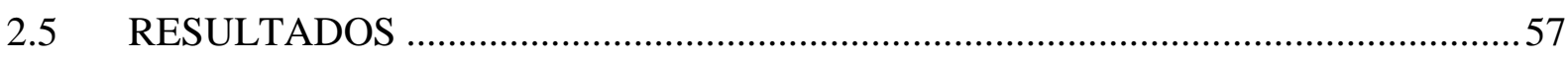

2.5.1 Estimação da probabilidade de uma firma ser exportadora .................................57

2.5.2 Estimação do custo fixo médio de entrada para a exportação nos países em desenvolvimento .........................................................................................................................559

2.5.3 Estimação do custo fixo de entrada para a exportação para cada país .................... 61

2.5.4 A relação entre os custos fixos de entrada para a exportação de cada país e a probabilidade da firma ser exportadora em cada país

2.5.5 A relação entre os custos fixos de entrada para a exportação e a qualidade das instituições

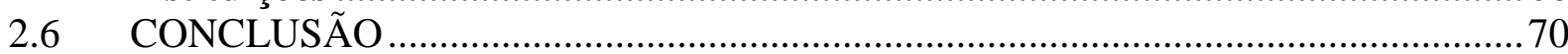

3 A DESONERAÇÃO SOBRE A FOLHA DE PAGAMENTOS E SUA RELAÇÃO COM O COMÉRCIO EXTERIOR ...........................................................................73

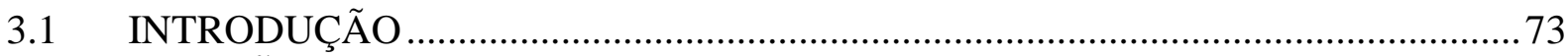

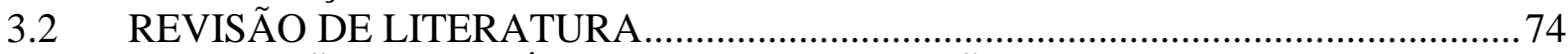

3.3 DESCRIÇÃO DA POLÍTICA DE DESONERAÇÃO

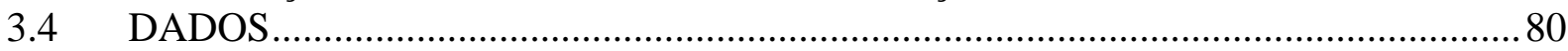

3.4.1 Exportação e Importação ................................................................................................80

3.4.2 Intensidade do fator trabalho ........................................................................... 81

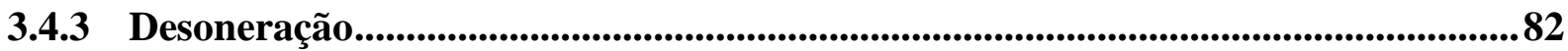

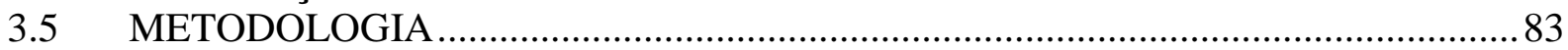




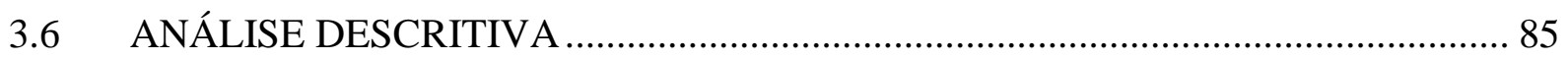

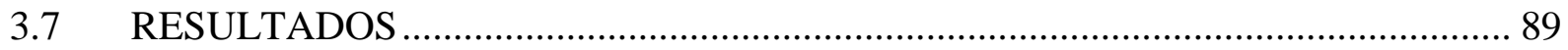

3.7.1 Impacto da desoneração sobre o total das exportações e importações.................. 89

3.7.2 Impacto da desoneração controlando por intensidade de mão-de-obra na

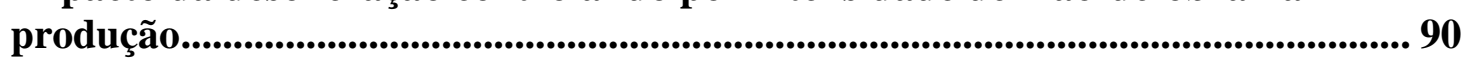

3.7.3 Estimações utilizando outras variáveis de intensidade do fator trabalho ............. 91

3.7.4 Estimações separando as desonerações em momentos distintos.............................. 93

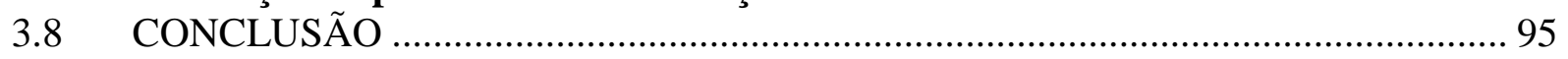

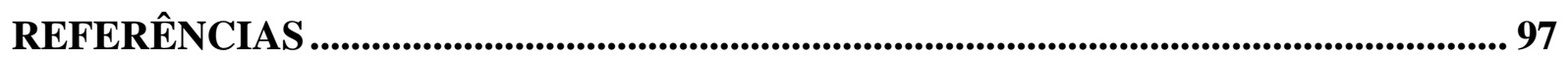

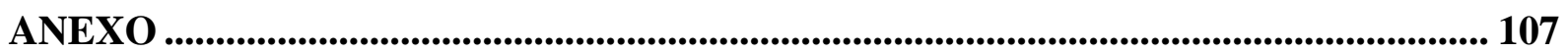




\section{A DISSEMINAÇÃO DOS CREDIT DEFAULT SWAPS ALTEROU A RELAÇÃO DAS AGÊNCIAS DE RISCO COM O MERCADO FINANCEIRO?}

\subsection{INTRODUÇÃO}

Tanto os ratings atribuídos pelas agências de risco ${ }^{1}$ como o ativo $\operatorname{CDS}^{2}$ avaliam a qualidade do crédito e, consequentemente, a probabilidade de default de uma instituição ou entidade soberana. Todavia, estes instrumentos diferem na forma como efetuam esta avaliação. A classificação de risco aferida pelas agências de risco é baseada na expertise destas e em informações que podem ou não ser públicas. As agências estão permanentemente avaliando os ratings atribuídos por elas a empresas e a entidades soberanas. Quando estas agências, com sua expertise, julgam com base nas informações por elas coletadas que precisam reclassificar a qualidade do crédito da entidade, elas anunciam a mudança. Já o CDS é um ativo comercializável no mercado financeiro, o que o leva a ter preço de mercado formado pela interação entre as crenças de todos os agentes econômicos baseadas em todas as informações públicas existentes. Além disso, este ativo é reprecificado a cada segundo, incorporando mudanças de crenças e/ou novas informações.

Na hipótese de as agências operarem de maneira tão eficiente quanto o mercado e sem informação privilegiada, a grande diferença entre o CDS e os ratings é que o primeiro é um processo contínuo enquanto que o segundo é discreto. Desta forma, o CDS deve ter substituído grande parte do papel dos ratings, inclusive antecipando fortemente as mudanças de rating. Contudo, as agências de rating podem ter acesso a algumas informações que não são públicas. Portanto, se estas informações forem decisivas na mensuração da qualidade do crédito, os ratings ainda podem ter importância no mercado, inclusive influenciando a cotação do CDS e, eventualmente, até antecipando o movimento do CDS.

Neste contexto, o presente ensaio visa estudar se o impacto de mudanças de rating soberano sobre o mercado financeiro sofreu alguma alteração após a ampliação da indústria de CDS. Até onde se tem conhecimento, este é o primeiro trabalho a discorrer sobre tal

\footnotetext{
${ }^{1}$ Entre outras atribuições, as agências de rating calculam a probabilidade do governo de determinado país honrar compromissos associados à dívida pública, analisando características como risco político, renda e estrutura econômica, perspectiva de crescimento, flexibilidade fiscal, estabilidade monetária e endividamento do estado. Para cada intervalo de probabilidade, as agências atribuem um rating soberano, que, segundo Cantor e Packer (1996), sumariza, efetivamente, as informações contidas nestes indicadores macroeconômicos. Vale notar que estas agências iniciaram, em média, a classificação dos ratings soberanos de países desenvolvidos nos anos 70 enquanto que de países emergentes este trabalho iniciou-se nos anos 90.

${ }^{2}$ CDS é a abreviação de Credit Default Swap, um derivativo que foi criado em 1994, e cujo contrato provê um seguro contra um default, nomeado evento de crédito, por uma determinada empresa ou entidade soberana. $\mathrm{O}$ comprador do seguro faz pagamentos periódicos ao vendedor do seguro em troca do direito de vender o ativo emitido pela entidade soberana ou empresa pelo valor de face no caso de ocorrência de um evento de crédito.
} 
assunto. Para alcançar os objetivos empregamos a metodologia de estudo de evento com base em dados diários de três ativos financeiros: bolsas de valores, taxas de câmbio e CDS, e de ratings soberanos atribuídos pela agência Standard \& Poor's. Estes dados foram extraídos para 37 países - 25 emergentes e 12 desenvolvidos - desde 1991 (ou a partir da existência ou disponibilidade destes) até 01 de julho de 2015.

Nossos resultados principais corroboram nossa hipótese geral de que o desenvolvimento do mercado de CDS reduziu a relevância do papel das agências de rating no mercado financeiro devido à similaridade do objeto analisado por ambos: a qualidade do crédito. Neste sentido encontramos, grosso modo, que dentre os demais ativos analisados o CDS é o que mais sofre o impacto das mudanças de rating além de ser o que mais antecipa estes eventos, colocando em evidência sua maior sinergia com os ratings.

Além disso, dividindo-se a amostra entre antes e depois de 2005 (ano em que a indústria de CDS se consolidou no mercado financeiro) os resultados encontrados deixam clara a redução do impacto das mudanças de rating sobre o mercado financeiro após a disseminação do derivativo. Por fim, encontramos também que os impactos das mudanças de rating sobre o câmbio ou a bolsa desaparecem quando utilizamos o CDS como controle na regressão.

Neste sentido, nosso ensaio se relaciona com a literatura que estuda o impacto dos ratings sobre os mercados. Em geral esta literatura aponta que reclassificações de risco soberano feitas pelas agências de rating, principalmente, pela Standard \& Poor's (agência líder do mercado), impactam de maneira estatisticamente significativa os ativos financeiros como títulos públicos, bolsas de valores, taxas de câmbio, derivativos, entre outros. Este resultado demonstra que as agências de rating provêm informação relevante ao mercado, principalmente quando se trata de downgrades. Porém, vale ressaltar que na maioria dos trabalhos os impactos encontrados são assimétricos; isto é, estatisticamente significantes para rebaixamento de ratings, mas insignificantes para elevação de rating.

Resultados assimétricos são encontrados, por exemplo, em trabalhos como os de Griffin e Sanvicente (1982), Hand, Holthausen e Leftwich (1992), Goh e Ederington (1993), Goh e Ederington (1998), Dickey e Piotroski (2001) e Martell (2005) que avaliam mudanças de rating sobre ações ou títulos de dívida. O mesmo ocorre na dissertação de mestrado de Scarabel (2010) e nos trabalhos de Treepongkaruna e Wu (2012), e Alsakka e Gwilym (2013) que estudam o efeito sobre a taxa de câmbio; e, finalmente, nos trabalhos de Hull, Predescu, White (2004), Norden e Weber (2004) e Ismailescu e Kazemi (2010) que examinam o impacto sobre o CDS. Além disso, estes últimos estudos mostram que, de maneira geral, o 
movimento do CDS antecipa mais do que outros ativos uma mudança de rating, e que, quando a mudança de rating se concretiza, ela afeta de maneira mais pronunciada o CDS do que outros ativos.

Os resultados do nosso ensaio corroboram os achados na literatura descritos acima, pois notamos que as reações às mudanças de rating são assimétricas e que a relação dos ratings com o CDS é mais acentuada do que com outros ativos. A partir deste ponto testamos se o próprio surgimento do mercado de CDS alterou o efeito das mudanças de rating sobre o mercado financeiro. Cremos que o presente ensaio é inovador, sendo o primeiro a se dedicar sobre tal assunto.

Para realizar esta segunda etapa, utilizamos o arcabouço de outra vertente da literatura, que analisa se o efeito de mudanças de rating soberano (assim como de seu efeito contágio) sobre os mercados aumenta ou diminui em tempos de crise. Basicamente, tal literatura compara os resultados das estimações obtidos dividindo-se a amostra em dois grupos: antes e depois da crise. Procedemos de forma análoga, porém dividindo a amostra entre antes e depois da disseminação do instrumento financeiro CDS.

Com relação à literatura de efeito contágio, destacam-se os trabalhos de Gande e Parsley (2005) e Ferreira e Gama (2007). Em geral, eles propõem que downgrades apresentam um efeito contágio significante e negativo, mas upgrades não apresentam efeito.

Por fim, com relação à literatura que avalia a alteração do efeito em tempos de crise, destacam-se os trabalhos de Alsakka e Gwilym (2013), Afonso, Furceri e Gomes (2012) e Treepongkaruna e Wu (2012) que, no geral, notam que em períodos de crise os ativos reagem com maior intensidade a mudanças de ratings e o efeito contágio também é maior.

O presente ensaio será apresentado da seguinte forma. Na seção 1.2, discorremos sobre os dados, detalhando a composição da amostra por países, blocos econômicos/geográficos, tipos de eventos etc. Na seção 1.3, explicamos brevemente, a metodologia utilizada neste ensaio, chamada de estudo de eventos. Na seção 1.4, mostramos estatísticas descritivas dos dados que ajudam a clarear e embasar as estimações seguintes. $\mathrm{Na}$ seção 1.5, apresentamos os resultados, os quais ganham corpo na seção seguinte (1.6) com testes de robustez. Finalmente, na seção 1.7, apresentamos a conclusão do ensaio. 


\subsection{DADOS}

\subsubsection{Países}

Nossa amostra é bastante abrangente, englobando 37 países. Tal monta representa em torno de $20 \%$ de todos os países existentes no mundo. A escolha por estes países se deu em função da facilidade de acesso aos dados, o que por sua vez reflete o grau de desenvolvimento e liquidez dos respectivos mercados financeiros. Dentre os 37 países, 25 são considerados emergentes e 12 são desenvolvidos. Tal aspecto diverge de diversos trabalhos que utilizam apenas países emergentes. O motivo de tal escolha é que, além da maior variabilidade de ratings - países emergentes são reclassificados com maior frequência do que os países desenvolvidos - estes países possuem maior assimetria de informação, o que exacerba o papel das agências de risco. Desta forma, com uma amostra onde um terço dos países são desenvolvidos, os resultados aqui encontrados são mais conservadores e podem ser entendidos como mais robustos do que em trabalhos onde a amostra só contempla países emergentes.

Com relação à classificação geográfica, nossa amostra também apresenta grande abrangência. Foram relacionados para o estudo dados de países desenvolvidos na Ásia, Oceania, América do Norte e Europa, bem como emergentes localizados na Ásia, Europa, América Latina e África.

\subsubsection{CDS, taxa de câmbio e Bolsa}

Em relação a cada país que compõe a nossa amostra, extraímos da Bloomberg o histórico da cotação diária: do câmbio nominal - moeda doméstica/US\$ e preço de fechamento; da cotação da bolsa do país - em moeda local e preço de fechamento; do Credit Default Swap (CDS) do título de dívida soberana do país com vencimento em 5 anos, com cotação em dólares americanos - preço de fechamento. Conforme a Tabela 1, a data de início destes ativos difere para cada país ${ }^{3}$ em função da disponibilidade destes dados em nosso terminal da Bloomberg. O mesmo ocorre no caso do CDS devido à prematuridade deste mercado. Os dados se estendem até 01 de julho de 2015.

\footnotetext{
${ }^{3}$ No caso dos EUA, utilizamos para o câmbio a cotação do índice DXY, o qual calcula o valor do dólar frente a uma cesta de moedas. Para Alemanha e Grécia utilizamos o Euro.
} 
A partir destas informações, ao longo do presente ensaio, calcularemos o retorno destes ativos em diversos instantes do tempo utilizando a expressão abaixo:

$$
\mathrm{R}_{\mathrm{ait}}=\ln \left(Q_{\mathrm{ait}}\right)-\ln \left(Q_{\mathrm{ait}-1}\right)
$$

Em que $Q_{a i t}$ é a cotação do ativo a do país i no dia t. Portanto, neste caso, para a taxa de câmbio ${ }^{4}$ um retorno positivo (ou negativo) expressa uma depreciação (ou apreciação) da moeda doméstica frente ao dólar, ao passo que para a bolsa um retorno positivo (ou negativo) expressa um(a) ganho (ou perda) com este ativo e, finalmente, para o CDS um retorno positivo (ou negativo) expressa uma piora (ou melhora) da percepção de risco.

Tabela 1 - Início dos dados por ativo e país

\begin{tabular}{|c|c|c|c|c|c|c|c|c|c|c|c|}
\hline & & Países & $\mathrm{CDS}$ & Bolsa & Câmbio & & & Países & $\operatorname{CDS}$ & Bolsa & Câmbio \\
\hline \multirow{25}{*}{ 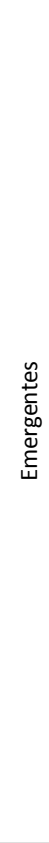 } & \multirow{9}{*}{ 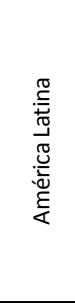 } & ARGENTINA & \multirow{2}{*}{\multicolumn{2}{|c|}{$\begin{array}{l}\text { 23/06/2005 09/01/1990 } \\
16 / 10 / 2001 \text { 03/01/1990 }\end{array}$}} & \multirow{3}{*}{$\begin{array}{l}06 / 01 / 1992 \\
16 / 01 / 1992 \\
02 / 01 / 1990\end{array}$} & \multirow{12}{*}{ 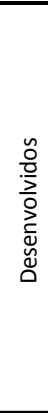 } & \multirow{2}{*}{ Oceânia } & AUSTRÁLIA & $29 / 09 / 2008$ & 01/06/199 & $02 / 01 / 1990$ \\
\hline & & BRASIL & & & & & & NOVA ZELÂNDIA & $06 / 01 / 2009$ & 31/03/199 & $02 / 01 / 1990$ \\
\hline & & CHILE & $27 / 01 / 2003$ & 03/01/1990 & & & \multirow{2}{*}{$\begin{array}{l}\text { América } \\
\text { do Norte }\end{array}$} & CANADÁ & $17 / 10 / 2015$ & 03/01/199 & $02 / 01 / 1990$ \\
\hline & & COLÔMBIA & $27 / 01 / 2003$ & $16 / 07 / 2002$ & 20/08/1992 & & & EUA & $03 / 09 / 2009$ & 03/01/199 & $03 / 01 / 1990$ \\
\hline & & \multirow{5}{*}{\begin{tabular}{|l} 
EQUADOR \\
MÉXICO \\
PANAMÁ \\
PERU \\
VENEZUELA \\
\end{tabular}} & 20/09/2006 & 04/01/1994 & \multirow{5}{*}{$\begin{array}{l}17 / 06 / 1993 \\
02 / 01 / 1990 \\
02 / 01 / 1990 \\
13 / 08 / 1992 \\
02 / 01 / 1990\end{array}$} & & \multirow[t]{8}{*}{ Ásia } & JAPÃO & $07 / 01 / 2003$ & $05 / 01 / 199$ & $02 / 01 / 1990$ \\
\hline & & & $16 / 10 / 2001$ & 20/01/1994 & & & & ALEMANHA & $18 / 03 / 2003$ & 03/01/199 & $01 / 02 / 2002$ \\
\hline & & & $04 / 11 / 2003$ & 15/01/1992 & & & & DINAMARCA & $31 / 01 / 2005$ & 03/01/199 & 02/01/1990 \\
\hline & & & $21 / 10 / 2003$ & 03/01/1990 & & & & INGLATERRA & $11 / 08 / 2008$ & 03/01/199 - - 2 & 02/01/1990 \\
\hline & & & $27 / 01 / 2003$ & 03/01/1994 & & & & ISLÂNDIA & 29/01/2013 & 04/01/199 & 24/11/1992 \\
\hline & \multirow{6}{*}{$\frac{5}{4}$} & \multirow{6}{*}{\begin{tabular}{|l|} 
CHINA \\
CORÉIA DO SUL \\
FILIPINAS \\
Ĺ́BANO \\
MALÁSIA \\
TAILÂNDIA \\
\end{tabular}} & $27 / 01 / 2003$ & 20/12/1990 & \multirow{4}{*}{$\begin{array}{l}02 / 01 / 1990 \\
02 / 01 / 1990 \\
06 / 11 / 1991 \\
22 / 06 / 1993\end{array}$} & & & NORUEGA & $19 / 02 / 2009$ & 03/01/199 & 02/01/1990 \\
\hline & & & $01 / 03 / 2002$ & 04/01/1990 & & & & SUÉCIA & $22 / 01 / 2004$ & 03/01/199 & 02/01/1990 \\
\hline & & & $12 / 04 / 2002$ & 03/01/1990 & & & & SuÍçA & 09/03/2009 & 04/01/199 & $02 / 01 / 1990$ \\
\hline & & & 20/10/2006 & 23/01/1996 & & & & & & & \\
\hline & & & 05/11/2001 & 03/01/1990 & 02/01/1990 & & & & & & \\
\hline & & & $12 / 04 / 2002$ & $03 / 01 / 1990$ & $02 / 01 / 1990$ & & & & & & \\
\hline & \multirow{7}{*}{ 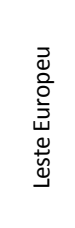 } & BULGÁRIA & $25 / 10 / 2000$ & $25 / 10 / 2000$ & 17/06/1993 & & & & & & \\
\hline & & CROÁCIA & & $17 / c$ & 1996 & & & & & & \\
\hline & & GRÉCIA & $18 / 03 / 2003$ & 03/01/1990 & $01 / 02 / 2002$ & & & & & & \\
\hline & & HUNGRIA & $18 / 03 / 2002$ & 03/01/1991 & 03/01/1990 & & & & & & \\
\hline & & POLÔNIA & $24 / 10 / 2000$ & 23/04/1991 & 21/06/1993 & & & & & & \\
\hline & & RÚSSIA & $20 / 10 / 2000$ & 23/09/1997 & $12 / 07 / 1993$ & & & & & & \\
\hline & & TURQUIA & $12 / 04 / 2002$ & $03 / 01 / 1990$ & $03 / 01 / 1990$ & & & & & & \\
\hline & \multirow{3}{*}{ África } & ÁFRICA DO SUL & $12 / 10 / 2000$ & 03/07/1995 & 02/01/1990 & & & & & & \\
\hline & & MARROCOS & $14 / 08 / 2014$ & $31 / 12 / 1993$ & 03/01/1990 & & & & & & \\
\hline & & NIGÉRIA & 02/01/2014 & 05/01/1998 & 22/03/1994 & & & & & & \\
\hline
\end{tabular}

Fonte: Autoria própria, baseada em Bloomberg

\subsubsection{Rating da Standard \& Poor's}

Utilizamos, ainda, o histórico diário de ratings soberanos atribuídos pela agência Standard and Poor's aos países que compõem nossa amostra. Esta agência, juntamente com a Moody's e a Fitch, é a principal agência de risco no mundo, e segundo diversos trabalhos como Gande e Parsley (2005), a Standard \& Poor's além de efetuar mudanças de rating com

\footnotetext{
${ }^{4} \mathrm{O}$ retorno da taxa de câmbio claramente é influenciado pelo regime cambial adotado pelo país. Comumente há dois tipos de classificação de regime cambial: a oficial do FMI (que sofre de diversas críticas) e a de Reinhart e Rogoff (2004) que é melhor, mas existente somente até 2007. Neste caso, optamos por não fazer nenhum tipo de controle em relação ao regime cambial, o que apenas tonará nossa análise mais conservadora.
} 
mais frequência, tem suas atuações menos antecipadas pelo mercado e desempenha um papel de liderança entre estas agências.

Conforme esclarecido pelas próprias agências em suas respectivas páginas na Internet (http://www2.standardandpoors.com; http://www.moodys.com; http://www.fitchratings.com), o rating de crédito soberano avalia a capacidade e disposição de um governo para honrar pontual e integralmente - o serviço de sua dívida. A avaliação da qualidade creditícia de cada governo soberano é quantitativa e qualitativa. Os aspectos quantitativos incluem várias medidas de desempenho econômico e financeiro, bem como as obrigações contingenciais, embora o julgamento sobre a integridade desses dados seja uma questão mais qualitativa. Tal análise é também qualitativa por conta da importância dos desdobramentos políticos e das políticas adotadas pelos governos soberanos.

Podemos destacar dez categorias que influenciam a estrutura analítica dos ratings soberanos, a saber: risco político, renda e estrutura econômica, perspectiva de crescimento econômico, flexibilidade fiscal, carga da dívida do governo, passivos contingenciais e no exterior, estabilidade monetária, liquidez externa, carga do endividamento externo do setor público e carga do endividamento externo do setor privado.

Neste estudo, um evento é definido como uma mudança na nota de crédito ou no outlook atribuídos a algum dos países da amostra pela agência Standard \& Poor's. Portanto, eventos positivos são upgrades ou uma melhora do outlook do país, enquanto que eventos negativos são downgrades ou redução do outlook. Ressalta-se que a cada nota corresponde a uma probabilidade de default. Portanto, quanto pior a nota, maior o risco de inadimplência apresentado pelo ativo. Além disso, há uma divisão em dois grandes grupos: grau de investimento e grau especulativo. Um país considerado grau de investimento tem uma baixa probabilidade de se tornar inadimplente enquanto que para um país que é classificado como grau especulativo esta probabilidade é alta. A classificação de um país entre grau de investimento ou grau especulativo é importante porque vários fundos de pensão e outras categorias de investimento mais conservadoras possuem regras em suas legislações que limitam o investimento em países classificados como grau especulativo.

Em nossa amostra, há 283 eventos, que são mudanças de rating ou outlook atribuídos pela agência Standard \& Poor's a algum dos 37 países que compõem a nossa amostra. Os eventos são bem distribuídos entre os tipos: há 133 eventos positivos e 150 negativos. Conforme mostra a Tabela 2, mesmo após a divisão da amostra entre antes e depois de 
01/01/2005, período ${ }^{5}$ que adotamos como o divisor de águas para separar a nossa amostra entre antes e depois da disseminação do mercado de CDS, a amostra se mantém bastante balanceada. Antes de 01/01/2005 há 144 eventos, sendo que 74 são positivos e 70 são negativos. A após 01/01/2005 há 139 eventos, sendo 59 positivos e 80 negativos. Portanto, a diferença encontrada entre os resultados obtidos nas duas subamostras não deve ser proveniente de algum problema da amostra.

Tabela 2 - Distribuição dos eventos por tipo de evento e período

\begin{tabular}{lrrr}
\hline & Período completo & Antes de 01/01/2005 & Depois de 01/01/2005 \\
\hline positivo & 133 & 74 & 59 \\
negativo & 150 & 70 & 80 \\
Total & 283 & 144 & 139 \\
\hline Proporção & & & \\
\hline positivo & $47 \%$ & $51 \%$ & $42 \%$ \\
negativo & $53 \%$ & $49 \%$ & $58 \%$ \\
\hline
\end{tabular}

Fonte: Autoria própria

Em relação à divisão dos eventos entre países emergentes e desenvolvidos, há uma clara predominância de eventos nos países emergentes, conforme demonstra a Tabela 3. Notase que $88 \%$ dos eventos ocorrem nos emergentes. Isto se deve a dois fatores: além destes serem 66\% da nossa amostra, como já comentamos anteriormente, estes países são mais vulneráveis e instáveis, o que implica em revisões de rating mais frequentes. Dentre os emergentes, todos os blocos contam com expressiva quantidade de eventos, com uma média de 9 eventos por país em cada bloco. Entre os desenvolvidos, esta média se situa em 3 eventos por país em cada bloco. Não há nenhuma concentração preocupante dos eventos por país, embora crises vividas por alguns países nas últimas três décadas façam com que haja naturalmente países com maior quantidade de eventos do que outros. É o caso, por exemplo, de Argentina, Venezuela, Coréia do Sul, Grécia e Rússia. Embora a maior quantidade de eventos para alguns países seja inevitável, o uso de dummies por país na estimação minimiza os problemas oriundos desta concentração.

\footnotetext{
${ }^{5}$ A escolha da data para dividir a amostra entre antes e depois da consolidação do mercado de CDS será discutida com mais detalhes à frente.
} 
Tabela 3 - Distribuição dos eventos por país e período

\begin{tabular}{|c|c|c|c|c|c|}
\hline & & & Período completo & Antes de 2005 & Depois de 2005 \\
\hline \multirow{30}{*}{ 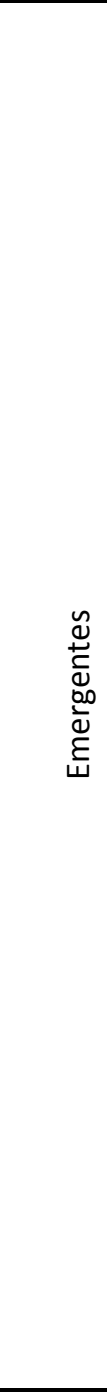 } & \multirow{10}{*}{ 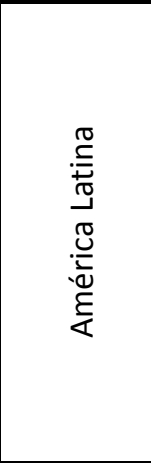 } & ARGENTINA & 22 & 11 & 11 \\
\hline & & BRASIL & 11 & 6 & 5 \\
\hline & & CHILE & 5 & 3 & 2 \\
\hline & & COLÔMBIA & 5 & 3 & 2 \\
\hline & & EQUADOR & 14 & 1 & 13 \\
\hline & & MÉXICO & 7 & 3 & 4 \\
\hline & & PANAMÁ & 4 & 1 & 3 \\
\hline & & PERU & 8 & 4 & 4 \\
\hline & & VENEZUELA & 21 & 12 & 9 \\
\hline & & TOTAL & 97 & 44 & 53 \\
\hline & \multirow{7}{*}{. } & CHINA & 7 & 3 & 4 \\
\hline & & CORÉIA DO SUL & 12 & 10 & 2 \\
\hline & & FILIPINAS & 8 & 3 & 5 \\
\hline & & LÍBANO & 11 & 4 & 7 \\
\hline & & MALÁSIA & 8 & 8 & 0 \\
\hline & & TAILÂNDIA & 9 & 7 & 2 \\
\hline & & TOTAL & 55 & 35 & 20 \\
\hline & \multirow{8}{*}{ 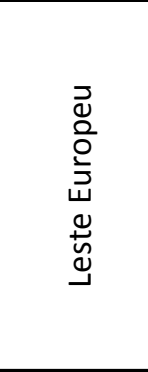 } & BULGÁRIA & 11 & 5 & 6 \\
\hline & & CROÁCIA & 4 & 1 & 3 \\
\hline & & GRÉCIA & 24 & 3 & 21 \\
\hline & & HUNGRIA & 12 & 4 & 8 \\
\hline & & POLÔNIA & 4 & 3 & 1 \\
\hline & & RÚSSIA & 18 & 11 & 7 \\
\hline & & TURQUIA & 11 & 9 & 2 \\
\hline & & TOTAL & 84 & 36 & 48 \\
\hline & \multirow{4}{*}{ África } & ÁFRICA DO SUL & 6 & 3 & 3 \\
\hline & & MARROCOS & 2 & 0 & 2 \\
\hline & & NIGÉRIA & 6 & 0 & 6 \\
\hline & & TOTAL & 14 & 3 & 11 \\
\hline & TOTAL & & 250 & 118 & 132 \\
\hline \multirow{17}{*}{ 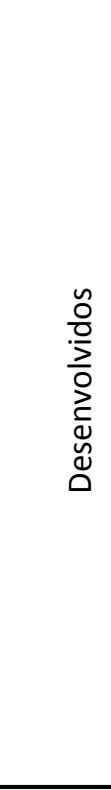 } & \multirow{3}{*}{ Oceânia } & AUSTRÁLIA & 2 & 2 & 0 \\
\hline & & NOVA ZELÂNDIA & 4 & 3 & 1 \\
\hline & & TOTAL & 6 & 5 & 1 \\
\hline & \multirow{3}{*}{$\begin{array}{l}\text { América } \\
\text { do Norte }\end{array}$} & CANADÁ & 2 & 2 & 0 \\
\hline & & EUA & 2 & 0 & 2 \\
\hline & & TOTAL & 4 & 2 & 2 \\
\hline & \multirow{2}{*}{ Ásia } & JAPÃO & 5 & 3 & 2 \\
\hline & & TOTAL & 5 & 3 & 2 \\
\hline & \multirow{8}{*}{$\begin{array}{l}\frac{\pi}{0} \\
\frac{0}{0} \\
\frac{3}{3}\end{array}$} & ALEMANHA & 2 & 0 & 2 \\
\hline & & DINAMARCA & 2 & 2 & 0 \\
\hline & & INGLATERRA & 0 & 0 & 0 \\
\hline & & ISLÂNDIA & 12 & 1 & 11 \\
\hline & & NORUEGA & 0 & 0 & 0 \\
\hline & & SUÉCIA & 2 & 2 & 0 \\
\hline & & SuÍçA & 0 & 0 & 0 \\
\hline & & TOTAL & 18 & 5 & 13 \\
\hline & \multicolumn{2}{|l|}{ TOTAL } & 33 & 15 & 18 \\
\hline TOTAL & & & 283 & 133 & 150 \\
\hline
\end{tabular}

Fonte: Autoria própria, baseada em Bloomberg 
Após a divisão da amostra em dois períodos, antes e depois de 01/01/2005, as duas subamostras não só são balanceadas entre quantidade e tipos de eventos como mostrado pela Tabela 3, como esta característica se estende em relação aos blocos econômicos /geográficos. Antes de 2005, há 118 eventos nos emergentes e 15 nos desenvolvidos, e após 2005 há 132 e 18 eventos, nesta mesma ordem. Esta homogeneidade entre subamostras e blocos se mantém para América Latina, Leste Europeu, África, América do Norte e Ásia desenvolvida. Vale notar que após 2005 há um claro aumento de eventos na Europa desenvolvida e na África, ao mesmo tempo em que há uma expressiva redução de eventos na Ásia emergente e na Oceania.

\subsection{METODOLOGIA}

A metodologia aplicada ao presente ensaio é chamada estudos de eventos ${ }^{6}$ amplamente discutida em trabalhos como o de Brown e Warner (1980, 1985), MacKinlay (1997) e Khotari e Warner (2006). De maneira geral, a ideia desta metodologia é diagnosticar se o comportamento do retorno de um ativo no dia do evento ou em sua vizinhança é estatisticamente diferente do comportamento costumeiro do retorno do ativo. Se assim for, conclui-se que o evento tem impacto no ativo.

Primeiramente, definem-se o ativo e o evento analisados. No presente ensaio, o evento em questão é a mudança de rating soberano e os ativos analisados são o câmbio nominal, CDS e o índice da Bolsa.

Calcula-se então o retorno acumulado do ativo, descrito aqui por $\mathrm{CR}_{\text {ait }}\left(\mathrm{t}_{1}, \mathrm{t}_{2}\right)$, que é a soma dos retornos diários desde $t_{1}$ até $t_{2}$, conforme mostrado pela equação (2).

$$
C R_{\text {ait }}\left(t_{1}, t_{2}\right)=\sum_{t=t_{1}}^{t_{2}} R_{\text {ait }}
$$

A escolha de $t_{1}$ e de $t_{2}$ fica a critério do pesquisador. Neste presente ensaio ${ }^{7}$, analisamos o $\mathrm{CR}_{\mathrm{ait}}(0,+1)$ que representa o retorno acumulado no dia do evento, marcado como $t=0$, e no dia posterior ao evento, marcado como $t=+1$, e serve para identificar se o evento teve efeito sobre o ativo. Além disso, analisamos também o $\mathrm{CR}_{\text {ait }}(-30,-1)$, que é o

\footnotetext{
${ }^{6}$ Para mais informações consulte o Anexo.

${ }^{7}$ No Anexo também é possível encontrar os resultados das nossas estimações para uma metodologia alternativa de estudo de eventos, o CAR, retorno acumulado anormal. Avaliamos o CAR $(-5,+5)$ e o CAR $(0,+1)$, que visam capturar o efeito do evento no retorno do ativo, e também o CAR $(-5,-1)$ e o CAR $(+2,+5)$, que pretendem identificar a antecipação do mercado e a existência de efeitos defasados, respectivamente. Todavia, estes resultados podem apresentar problemas conforme explicado por Gande e Parsley (2005). Vale notar que a janela de estimação utilizada para o cálculo do retorno normal nestes exercícios foi de 30 dias.
} 
retorno acumulado desde o trigésimo dia anterior ao evento até o dia imediatamente precedente ao evento, a fim de captar a antecipação do ativo ao evento.

Para a estimação usamos os dados de todos os países (i) que compõem a nossa amostra em toda data de evento (t). Ou seja, utilizamos em um dia de evento não só os dados do país que sofreu a mudança de rating como também os dados dos demais países analisados, o que permite controlar a análise por efeitos agregados, como, por exemplo, crises globais que afetem todos os países. Desta forma, no geral, nosso conjunto de dados tem uma estrutura de painel, isto é, 283 eventos e 37 países, gerando um total de mais de 10 mil observações.

Para cada ativo separadamente, seguindo a literatura padrão de estudo de evento, estimamos o modelo básico representado pela equação (3):

$$
y_{i t}=\propto+\beta_{1} \text { down }_{i t}+\beta_{2} u p_{i t}+\sum_{k} \beta_{k} X_{k}+\varepsilon_{i t}
$$

As variáveis explicadas, $\mathrm{y}_{\mathrm{it}}$, no nosso modelo são: $\mathrm{CR}_{\mathrm{ait}}(0,+1)$ e $\mathrm{CR}_{\mathrm{ait}}(-30,-1)$.

As variáveis explicativas down e up são dummies que assumem valor 1 se ocorreu o evento negativo e positivo, respectivamente, e zero caso contrário. A matriz $\mathrm{X}$ contém controles como dummies para países e dummies identificando o dia do evento. A finalidade destas variáveis é, respectivamente, controlar por características do país que não variam no tempo e controlar por efeitos agregados. Na sequência, permitimos que novas variáveis explicativas sejam adicionadas a esta matriz.

\subsection{ESTATÍSTICA DESCRITIVA}

Como argumentado anteriormente, caso a Standard \& Poor's contribua com informação nova/relevante ao mercado, os ativos irão responder às mudanças de suas classificações de risco. No caso de um evento negativo, conforme definido por nós previamente, o câmbio deve depreciar, a bolsa deve perder valor e o CDS deve aumentar. Já no caso de um evento positivo, o câmbio deve apreciar, a bolsa deve ganhar valor e o CDS deve diminuir. Todavia, segundo a literatura existente sobre impacto de mudanças de rating em ativos, notou-se que o usual é encontrar efeitos significativos para eventos negativos, enquanto que para eventos positivos não há reação estatisticamente significante por parte do mercado. 
Examinamos a variável dependente $\operatorname{CR}(0,+1)$ para cada ativo analisado neste ensaio para identificar se houve alguma reação dos ativos ao anúncio de alteração de avaliação de risco soberano. Inicialmente, faremos apenas a estatística descritiva destas variáveis condicionadas ao tipo de evento. Estas estatísticas condicionadas à ocorrência de eventos positivos e a eventos negativos estão reportados na Tabela 4.

\begin{tabular}{ccccc} 
Tabela 4 - Estatística descritiva de CR $(0,+1)$ condicionada à ocorrência de evento positivo \\
\cline { 2 - 5 } & \multicolumn{5}{c}{ Média } & Desvio-padrão & [Intervalo de confiança 95\%] \\
\hline \hline CDS & $-1.60 \%$ & $0.60 \%$ & $-2.79 \%$ & $-0.41 \%$ \\
Moeda & $-0.10 \%$ & $0.11 \%$ & $-0.32 \%$ & $0.13 \%$ \\
Bolsa & $0.38 \%$ & $0.23 \%$ & $-0.08 \%$ & $0.83 \%$ \\
\hline \multicolumn{5}{c}{ Evento positivo } \\
CDS & $5.76 \%$ & $1.82 \%$ & $2.10 \%$ & $9.42 \%$ \\
Moeda & $1.06 \%$ & $0.37 \%$ & $0.33 \%$ & $1.79 \%$ \\
Bolsa & $-0.94 \%$ & $0.46 \%$ & $-1.85 \%$ & $-0.04 \%$ \\
\hline
\end{tabular}

Fonte: Autoria própria

Os resultados da Tabela 4 corroboram os achados da literatura ao mostrar que os ativos usualmente não reagem a eventos positivos, no entanto, reagem a eventos negativos. Diante de eventos positivos, embora a média do $\mathrm{CR}(0,+1)$ da bolsa e da moeda apresentem o sinal esperado, eles não podem ser considerados estatisticamente diferentes de zero. A exceção é o ativo CDS, que é o único que é estatisticamente diferente de zero e aponta para uma queda do CDS de 1,6\% quando há um evento positivo. Este resultado já mostra sinais da maior sinergia do ativo CDS com o papel dos ratings em relação aos demais ativos.

Já quando condicionados a eventos negativos, todos os ativos - CDS, bolsa e câmbio apresentam alguma reação estatisticamente diferente de zero e na direção correta. A análise do $\mathrm{CR}(0,+1)$ mostra que, diante de um evento negativo, o CDS aumenta de valor em 5,76\%, piorando a percepção de risco do país. Além disso, a moeda do país rebaixado deprecia em média $1,06 \%$ e a bolsa desvaloriza $0,94 \%$. Embora, todos os ativos apresentem uma reação estatisticamente significante ao evento negativo, a magnitude da reação do CDS se sobressai àquela apresentada pela moeda ou pela bolsa. Tal resultado mostra que, também no caso de um evento negativo, o CDS tem maior vínculo com os ratings do que os outros ativos analisados.

Com relação à estatística da variável que capta a antecipação do evento, o CR(-30,-1), os resultados da Tabela 5 mostram que apenas o CDS e a bolsa antecipam de maneira 
estatisticamente significante o evento positivo. Neste sentido, o CDS cai em média 7,74\% e a bolsa valoriza $2,86 \%$.

Tabela 5 - Estatística descritiva de CR(-30,-1) condicionada à ocorrência de evento positivo e negativo Média Desvio-padrão [Intervalo de confiança 95\%]

\begin{tabular}{ccccc}
\hline \hline \multicolumn{5}{c}{ Evento positivo } \\
CDS & $-7.74 \%$ & $2.31 \%$ & $-12.35 \%$ & $-3.13 \%$ \\
Moeda & $-0.02 \%$ & $0.28 \%$ & $-0.57 \%$ & $0.54 \%$ \\
Bolsa & $2.86 \%$ & $0.75 \%$ & $1.38 \%$ & $4.33 \%$ \\
\hline \multicolumn{5}{c}{ Evento negativo } \\
CDS & $18.76 \%$ & $4.97 \%$ & $8.78 \%$ & $28.74 \%$ \\
Moeda & $3.97 \%$ & $0.86 \%$ & $2.26 \%$ & $5.68 \%$ \\
Bolsa & $-5.22 \%$ & $1.41 \%$ & $-8.01 \%$ & $-2.43 \%$ \\
\hline
\end{tabular}

Fonte: Autoria própria

Já quando se condiciona estas variáveis a eventos negativos, todos ativos mostram haver alguma antecipação captados através da variável CR(-30,-1). O CDS se eleva em $18,76 \%$, a moeda deprecia $3,97 \%$ e a bolsa cai $5,22 \%$. Também para o caso da análise de antecipação do evento, a magnitude dos efeitos para o ativo CDS é bem mais pronunciada do que para a bolsa ou para o câmbio.

Esta simples análise sugere que, em linha com a literatura do tema, os ativos reagem mais a eventos negativos do que a eventos positivos. Com relação ao efeito causado pelo evento captado pela variável $\mathrm{CR}(0,+1)$, apenas o CDS mostra reação a um evento positivo, enquanto que todas as variáveis apresentam reação quando o evento é negativo. Com relação à antecipação, quando há um evento positivo, tanto CDS quanto a bolsa reagem antecipadamente. Já quando o evento é negativo, todos os ativos apresentam antecipação. Vale notar, também, que a magnitude do efeito encontrado para o CDS supera sobremaneira a encontrada para os outros dois ativos.

Em suma, esta análise simples nos permitiu identificar que o CDS é o ativo mais sensível aos eventos de mudança de classificação de risco por parte da agência Standard \& Poor's $(S \& P)$, pois é o ativo que mais apresenta resultados estatisticamente significantes e com variações de maior magnitude. Todos estes resultados vão ao encontro de nossas hipóteses de que o CDS é o ativo de maior sinergia com o trabalho das agências de risco e que, pelo fato do CDS avaliar o risco de crédito de maneira contínua no tempo, ele consegue antecipar fortemente uma mudança de classificação de risco pela $S \& P$ que ocorre de forma discreta no tempo. 


\subsection{RESULTADOS}

\subsubsection{Modelo básico}

Após a seção anterior sugerir que nossas hipóteses estão corretas, prosseguimos com a estimação dos modelos de estudo de evento. Iniciamos com a apresentação dos resultados do modelo básico, equação (3) que regride as variáveis explicativas $\mathrm{CR}(0,+1)$ e $\mathrm{CR}(-30,-1)$, para cada ativo separadamente, em função de eventos positivos e negativos e dummies de período e de país utilizando a amostra completa.

Tabela 6 - Resultados do modelo básico

\begin{tabular}{|c|c|c|c|}
\hline & & up & down \\
\hline \multirow{2}{*}{ CDS } & $\mathrm{CR}(0,+1)$ & $-1,46 \% * *$ & $4,54 \% * * *$ \\
\hline & CR(-30,-1) & $-4,51 \% * *$ & $10,84 \% * * *$ \\
\hline \multirow{2}{*}{ Moeda } & $\mathrm{CR}(0,+1)$ & $-0,15 \%$ & $0,96 \% * * *$ \\
\hline & $\mathrm{CR}(-30,-1)$ & $-0,21 \%$ & $2,78 \% * * *$ \\
\hline \multirow{2}{*}{ Bolsa } & $\mathrm{CR}(0,+1)$ & $0,24 \%$ & $-0,47 \% * *$ \\
\hline & CR(-30,-1) & $1,16 \%$ & $-3,65 \% * * *$ \\
\hline
\end{tabular}

Fonte: Autoria própria

No geral, os resultados da Tabela 6 corroboram a análise das estatísticas descritivas realizada na seção anterior assim como os achados da literatura. Encontramos efeitos assimétricos dependendo do tipo de evento. Moeda e bolsa não apresentam qualquer reação a eventos positivos. Contudo, o CDS - a um nível de significância de 5\% - apresenta queda nos trinta dias que precedem o anúncio da melhora de classificação de rating e no ato do anúncio de $4,51 \%$ e de $1,46 \%$, respectivamente. Portanto, uma melhora da percepção de risco efetuada pela $S \& P$ faz o CDS também reduzir o risco atribuído àquele ativo. Vale notar que, além do CDS ser o único ativo a reagir a um evento positivo, a magnitude da antecipação é bastante superior à reação no ato do anúncio ${ }^{8}$.

No caso de eventos negativos, todos os ativos mostram tanto uma reação no dia do anúncio do evento quanto uma antecipação estatisticamente significantes. A moeda perde valor em face a uma piora da avaliação de risco do país feita pela $S \& P$, isto é, em média, ela deprecia no ato do anúncio e nos 30 dias precedentes ao evento 0,96\% e 2,78\%, respectivamente. No mercado de bolsa, a reação no dia do evento é menor, a bolsa cai $0,47 \%$, porém a antecipação é bastante intensa, com a bolsa caindo 3,65\%. No caso do CDS, o

\footnotetext{
${ }^{8}$ Todavia, se dividirmos pelo número de dias do período analisado, esta relação se inverte.
} 
anúncio de um evento negativo faz o ativo incorporar a piora da avaliação do risco atribuído pela $S \& P$ aumentando seu valor em $4,54 \%$ no dia do evento, e com relação à antecipação, o CDS aumenta em mais de $10 \%$ mesmo antes do anúncio do evento negativo.

Os resultados do modelo básico corroboram nossa hipótese de que o CDS é o ativo com maior sinergia com o papel executado pelas agências de risco e que, de modo geral, os eventos são antecipados.

\subsubsection{Separação da amostra entre antes e depois do boom do mercado de CDS}

Antes de prosseguirmos, vale revisitar nossa hipótese: o CDS, por compreender grande parte da informação proferida pelos ratings e por ser precificado de maneira contínua no tempo - refletindo a cada segundo a avaliação de todos os agentes econômicos sobre a qualidade do crédito de uma entidade soberana ou instituição - acabaria, em última instância, substituindo ou reduzindo, de certa forma, a relevância dos ratings para o mercado financeiro. Sendo assim, comprovada a grande sinergia entre o CDS e os ratings, assim como a expressiva antecipação de um evento capturada pelo movimento do CDS nas subseções anteriores, passamos a testar se a consolidação do mercado de CDS modificou a forma como os demais ativos reagem a mudanças de reclassificações de rating atribuídas pela $S \& P$.

Nesta subseção, replicamos a estimação feita na subseção 1.5.1 dividindo a amostra em dois períodos, antes e depois de 01/01/2005, ano que marca a consolidação do mercado de CDS. Foi em 2005 que o estoque total de CDS alcançou uma marca próxima ao montante atual, conforme podemos ver na Figura 1.

\footnotetext{
${ }^{9}$ Não há um ano exato que marque o despontamento do mercado de CDS, todavia fica claro que na primeira metade dos anos 2000 seu crescimento foi exponencial e alcançou um estoque de ativos em dólares equivalente ou superior ao montante atual. A fim de trazer mais luz a esta questão, temos uma subseção na seção de robustez que trata com mais detalhes deste tema.
} 
Figura 1 - Estoque total de Credit Default Swaps (trilhões de dólares)

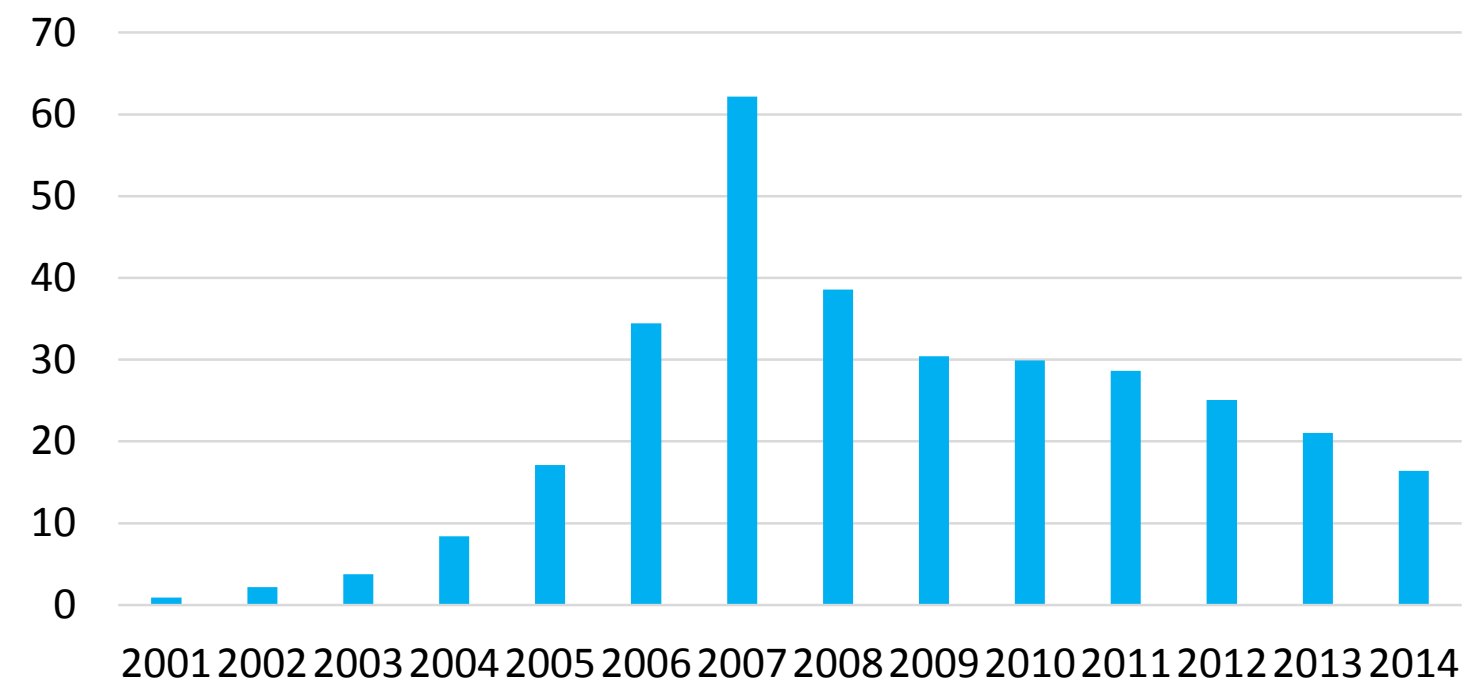

Fonte:ISDA

O intuito deste estudo foi verificar se os ativos alteram sua reação às mudanças de rating quando o mercado de CDS aflora. Vale notar que não faz sentido analisarmos o CDS, pois queremos captar se a reação aos ratings mudou justamente pelo desenvolvimento do mercado de CDS. Além disso, como é um instrumento financeiro recente, a quantidade de dados para o CDS antes de 01/01/2005 é limitada.

Tabela 7 - Comparação da reação entre antes e depois de 01/01/2005

\begin{tabular}{cccccc}
\hline & & \multicolumn{2}{c}{ Antes de 01/01/2005 } & \multicolumn{2}{c}{ Depois de 01/01/2005 } \\
\hline \hline \multirow{2}{*}{ Moeda } & & up & down & up & down \\
& $\mathrm{CR}(0,+1)$ & $-0,32 \%^{* *}$ & $1,95 \%^{* * *}$ & $0.01 \%$ & $0,22 \%^{* *}$ \\
& $\mathrm{CR}(-30,-1)$ & $-0.40 \%$ & $4,79 \%^{* * *}$ & $-0.11 \%$ & $1,00 \%^{* * *}$ \\
\hline \multirow{2}{*}{ Bolsa } & $\mathrm{CR}(0,+1)$ & $0.46 \%$ & $-0.05 \%$ & $0.01 \%$ & $-0,69 \%^{* * *}$ \\
& $\mathrm{CR}(-30,-1)$ & $1.15 \%$ & $-6,87 \% * * *$ & $1.00 \%$ & $-0.75 \%$ \\
\hline
\end{tabular}

${ }^{*}$ signficante a $10 \%,{ }^{* *}$ significante a $5 \%$ e ${ }^{* * *}$ signficantes a $1 \%$

Fonte: Autoria própria

Como mostrado pela Tabela 7, o mercado de câmbio claramente é menos impactado pelas mudanças de rating depois de 2005. Até 2005, o anúncio de um evento positivo fazia a moeda apreciar 0,32\% a um nível de significância de 5\%. Já após 2005, os eventos positivos deixam de afetar significativamente este mercado. Com relação aos eventos negativos, até 2005, a moeda depreciava no dia do anúncio do rebaixamento e nos 30 dias precedentes ao evento $1,95 \%$ e $4,79 \%$, respectivamente; ambos os efeitos estatisticamente significantes a $1 \%$ de nível de significância. Após 2005 os eventos negativos continuam fazendo a moeda perder 
valor frente ao dólar americano, porém a magnitude do efeito caiu substancialmente. A variável $\mathrm{CR}(0,+1)$ passa a ser estatisticamente significante apenas a $5 \%$ de nível de significância e não mais a $1 \%$ como acontecia até 2005 , e a depreciação ocorrida no dia do anúncio passa a ser de apenas 0,22\%. A depreciação da moeda que ocorre nos 30 dias antecedentes ao evento negativo continua a ser significante a $1 \%$ de nível de significância, mas a magnitude também caiu consideravelmente de 4,79\% para apenas 1,0\%.

Para a bolsa, os resultados não são tão evidentes como os obtidos com o mercado de câmbio, mas mesmo assim há uma relevante mudança. Os impactos aos eventos positivos continuam não sendo estatisticamente significantes e diminuem em magnitude. Com relação aos eventos negativos antes de 2005, a bolsa não apresentava efeito significante no dia do evento, mas antecipava o movimento caindo 6,87\% nos 30 dias precedentes ao rebaixamento isso a um nível de significância de 1\%. Após 2005, o efeito do rebaixamento no dia do anúncio passa a ser significante a $1 \%$ de nível de significância, mas o efeito de antecipação do evento deixa de ser significante. Vale notar que, após 2005, o rebaixamento faz a bolsa perder valor em apenas $0,69 \%$.

Diante destes resultados, podemos afirmar, grosso modo, que o impacto das reclassificações de rating sobre o mercado diminuiu após 01/01/2005. O que, em nossa opinião é, ao menos em parte, consequência da consolidação do mercado de CDS.

Nesta altura do estudo, um ponto de dúvida que pode vir à tona é se o resultado encontrado na subseção 1.5.1, o qual mostra a maior sinergia dos ratings com o ativo CDS do que com os demais ativos se mantém quando restringimos a amostra para após 01/01/2005. Sendo assim, na próxima tabela, comparamos as estimações para a amostra após 01/01/2005 para os três ativos. E assim como para a amostra completa, o efeito no CDS se sobressai ao dos demais ativos na amostra restrita.

Tabela 8 - Resultados do modelo básico para a amostra após 01/01/2005

\begin{tabular}{cccc}
\hline & & up & down \\
\hline \multirow{2}{*}{ CDS } & $\mathrm{CR}(0,+1)$ & $-1,74 \% * *$ & $4,61 \% * * *$ \\
& $\mathrm{CR}(-30,-1)$ & $-3,18 \%$ & $9,57 \% * * *$ \\
\hline \multirow{2}{*}{ Moeda } & $\mathrm{CR}(0,+1)$ & $0,01 \%$ & $0,22 \% * *$ \\
& $\mathrm{CR}(-30,-1)$ & $-0,11 \%$ & $1,00 \% * * *$ \\
\hline \multirow{2}{*}{ Bolsa } & $\mathrm{CR}(0,+1)$ & $0,01 \%$ & $-0,69 \% * * *$ \\
& $\mathrm{CR}(-30,-1)$ & $1,00 \%$ & $-0,75 \%$ \\
\hline \multirow{2}{*}{${ }^{*}$ signficante a 10\%, ** significante a 5\% e ${ }^{\text {*** }}$ signficantes a $1 \%$} &
\end{tabular}

Fonte: Autoria própria 


\subsubsection{Estimações utilizando o CDS como controle}

Além de dividir a amostra em dois períodos (antes e depois da consolidação do mercado de CDS), outra abordagem para verificar se o amadurecimento deste mercado modificou a relação das agências de rating com os demais ativos é utilizar o CDS como controle na regressão de análise de evento. Sendo assim, nesta subseção, adicionamos à equação (3) a variação do CDS nos trinta dias que antecedem ao evento como variável controle da estimação, conforme expressado pela equação (4), abaixo. Acreditamos que, controlando pelo CDS, alguns efeitos das mudanças de rating nos ativos se tornem mais fracos, e em alguns casos até deixem de ser estatisticamente significantes. Dada a restrição com relação aos dados de CDS, nossa estimação se refere ao período posterior a 01/01/2005.

$$
y_{i t}=\propto+\beta_{1} \text { down }_{i t}+\beta_{2} u p_{i t}+\beta_{3} C R_{C D S i t}(-30,-1)+\sum_{k} \beta_{k} X_{k}+\varepsilon_{i t}
$$

Conforme mostra a Tabela 9, a nossa expectativa se confirma. No mercado de moedas, no caso de eventos negativos, a variável $\mathrm{CR}(0,+1)$ - que é significante a $5 \%$ de nível de significância - e a variável CR(-30, -1) - que é significante a $1 \%$ de nível de significância nas equações básicas (sem controle) deixam de ser significantes e a magnitude do efeito muda completamente quando introduzimos o CDS como variável de controle. Além disso, na equação cuja variável dependente é o CR(-30,-1), o CDS como controle é uma variável explicativa estatisticamente significante a $1 \%$ de nível de significância.

Para o mercado de bolsa, como visto anteriormente, na equação básica (sem controle) o único efeito estatisticamente significante é da variável $\mathrm{CR}(0,+1)$ diante de um evento negativo. Quando introduzimos o CDS como controle, o efeito de um evento negativo sobre a variável $\mathrm{CR}(0,+1)$ da bolsa deixa de ser estatisticamente significante e a magnitude cai de $0,69 \%$ para $-0,41 \%$. Vale notar que a variável de controle é estatisticamente significante a $1 \%$ de nível de significância no caso da regressão da variável CR(-30,-1) da bolsa.

Além disso, a variável controle CDS tem a direção esperada por nós em todas as regressões. Ou seja, tem uma relação positiva com o câmbio, pois em eventos negativos (ou positivos), o CDS sobe (ou cai) e o câmbio também, indicando depreciação (ou apreciação). Já com a bolsa a relação é negativa, pois diante de uma revisão para baixo (ou para cima) do rating a bolsa sofre uma queda (ou elevação), enquanto que o CDS sobe (ou cai). 
Tabela 9 - Resultados do modelo utilizando o CDS como variável de controle

\begin{tabular}{ccccccc}
\hline & & \multicolumn{2}{c}{ Sem CDS como controle ${ }^{1}$} & \multicolumn{2}{c}{ Com CDS como controle $^{2}$} \\
\hline \hline \multirow{2}{*}{ Moeda } & & up & down & up & down & CDS \\
& $\mathrm{CR}(0,+1)$ & $0.01 \%$ & $0,22 \% * *$ & $0.05 \%$ & $-0.08 \%$ & $0.13 \%$ \\
& $\mathrm{CR}(-30,-1)$ & $-0.11 \%$ & $1,00 \% * * *$ & $-0.50 \%$ & $-0.36 \%$ & $2,69 \% * * *$ \\
\hline \multirow{2}{*}{ Bolsa } & $\mathrm{CR}(0,+1)$ & $0.01 \%$ & $-0,69 \% * * *$ & $0.09 \%$ & $-0.41 \%$ & $-0.11 \%$ \\
& $\mathrm{CR}(-30,-1)$ & $1.00 \%$ & $-0.75 \%$ & $0.10 \%$ & $0.19 \%$ & $-7,25 \% * * *$ \\
\hline
\end{tabular}

* signficante a $10 \%$, ** significante a $5 \% \mathrm{e}^{* * *}$ signficantes a $1 \%$

${ }^{1}$ referente à equação $(3) ;{ }^{2}$ referente à equação (4)

Fonte: Autoria própria

$\mathrm{Na}$ seção de robustez, mostramos que em comparação a outros ativos o CDS desempenha um papel de destaque como variável controle.

\subsection{ROBUSTEZ}

\subsubsection{Escolha do período de boom do mercado de CDS}

O desenvolvimento do mercado de CDS ganhou um grande impulso na primeira metade dos anos 2000. Mas, a escolha de um período exato para marcar a separação entre antes e depois do boom do mercado de CDS é desafiadora. Neste ensaio, adotamos o ano de 2005 (mais precisamente 01/01/2005) como sendo este divisor de águas, pois é neste ano que o estoque em dólares deste ativo ultrapassou a marca de US\$ 15 trilhões (5\% do total de estoque do mercado de derivativos), valor semelhante ao existente no período atual, segundo dados do ISDA ${ }^{10}$, órgão internacional de regulação do mercado de swaps e derivativos. Outro ano que pode ser considerado determinante na evolução deste mercado é 2003. Neste ano, o ISDA adotou uma série de regulamentações ${ }^{11}$ para este mercado como, por exemplo, uma definição exata para evento de crédito, o que contribuiu para a expansão deste mercado.

Neste sentido, nesta subseção pretendemos avaliar se a conclusão ${ }^{12}$ que chegamos até o presente momento continua válida quando mudamos o ano que tomamos como divisor de águas para marcar o desenvolvimento do mercado de CDS.

Conforme a tabela a seguir, ao adotarmos 01/01/2003 ao invés de 01/01/2005, os resultados pouco se alteram. $\mathrm{O}$ efeito das mudanças de rating continua enfraquecendo tanto em relação à sua relevância estatística quanto em relação à sua magnitude.

\footnotetext{
${ }^{10}$ http://www2.isda.org/

${ }^{11}$ Conforme explicado em Anderson (2010)

${ }^{12} \mathrm{O}$ efeito das mudanças de rating soberano sobre os ativos financeiros tem diminuído ao longo do tempo, e uma possível causa desta perda de relevância foi o desenvolvimento do mercado de CDS.
} 
Tabela 10 - Adoção da data 01/01/2003 como divisor de águas

\begin{tabular}{cccccc} 
& \multicolumn{2}{c}{ Antes de $01 / 01 / 2003$} & \multicolumn{2}{c}{ Depois de $01 / 01 / 2003$} \\
\hline \hline \multirow{2}{*}{ Moeda } & & up & down & up & down \\
& $\mathrm{CR}(0,+1)$ & $-0,40 \% * *$ & $2,00 \%^{* * *}$ & $0.00 \%$ & $0,20 \% * *$ \\
& $\mathrm{CR}(-30,-1)$ & $0.10 \%$ & $5,10 \% * * *$ & $-0.40 \%$ & $0,90 \% * *$ \\
\hline \multirow{2}{*}{ Bolsa } & $\mathrm{CR}(0,+1)$ & $0.40 \%$ & $0.00 \%$ & $0.20 \%$ & $-0,70 \% * * *$ \\
& $\mathrm{CR}(-30,-1)$ & $1.60 \%$ & $-7,30 \% * * *$ & $0.80 \%$ & $-0.70 \%$ \\
\hline
\end{tabular}

* signficante a $10 \%,{ }^{* *}$ significante a $5 \%$ e *** signficantes a $1 \%$

Fonte: Autoria própria

Sendo ainda mais conservadores, adotamos para o boom do mercado de CDS, o período entre 01/01/2003 e 01/01/2005. Ou seja, antes de 01/01/2003 é o período cujo mercado de CDS carece de regulamentação e possui um estoque de aproximadamente US\$ 2 trilhões. Enquanto que, a partir de 01/01/2005, o mercado apresenta regulamentação robusta e atinge um estoque US\$ 15 trilhões. Mesmo assim, a conclusão que chegamos anteriormente não se altera, conforme mostra a tabela a seguir.

Tabela 11 - Abordagem conservadora

\begin{tabular}{cccccc} 
& & \multicolumn{2}{c}{ Antes de 01/01/2003 } & \multicolumn{2}{c}{ Depois de 01/01/2005 } \\
\hline \hline \multirow{2}{*}{ Moeda } & & up & down & up & down \\
& $\mathrm{CR}(0,+1)$ & $-0,40 \% * *$ & $2,00 \% * * *$ & $0.01 \%$ & $0,20 \% * *$ \\
& $\mathrm{CR}(-30,-1)$ & $0.10 \%$ & $5,10 \% * * *$ & $-0.11 \%$ & $1,00 \% * * *$ \\
\hline \multirow{2}{*}{ Bolsa } & $\mathrm{CR}(0,+1)$ & $0.40 \%$ & $0.00 \%$ & $0.01 \%$ & $-0,60 \% * * *$ \\
& $\mathrm{CR}(-30,-1)$ & $1.60 \%$ & $-7,30 \% * * *$ & $1.00 \%$ & $-0.75 \%$ \\
\hline
\end{tabular}

${ }^{*}$ signficante a $10 \%,{ }^{* *}$ significante a $5 \% \mathrm{e}^{* \star *}$ signficantes a $1 \%$

Fonte: Autoria própria

Neste contexto, a fim de testar se os resultados que encontramos acima (diminuição do efeito de mudanças de rating sobre os ativos financeiros) estão mais associados à perda de credibilidade destas agências devido às suas falhas em preverem a crise de 2008 do que ao desenvolvimento do mercado de CDS, estimamos as tabelas a seguir. A primeira tabela compara o ano precedente e o subsequente à crise e, a despeito da limitação de observações, ela sinaliza que, no mínimo, não se pode afirmar que a crise de 2008 fez a relevância dos ratings diminuir no curto prazo. 
Tabela 12 - Efeito da crise de 2008

\begin{tabular}{cccccc} 
& & \multicolumn{2}{c}{2007} & \multicolumn{2}{c}{2009} \\
\hline \hline \multirow{2}{*}{ Moeda } & & up & down & up & down \\
& $\mathrm{CR}(0,+1)$ & $-0,40 \% *$ & $-0,10 \%$ & $0,30 \%$ & $-0,10 \%$ \\
& $\mathrm{CR}(-30,-1)$ & $0,20 \%$ & $-0,90 \%$ & $-0,70 \%$ & $-0,20 \%$ \\
\hline \multirow{2}{*}{ Bolsa } & $\mathrm{CR}(0,+1)$ & $0,60 \%$ & $0,20 \%$ & $-4,40 \% * * *$ & $-1,60 \% *$ \\
& $\mathrm{CR}(-30,-1)$ & $1,10 \%$ & $3,60 \%$ & $-3,60 \%$ & $-6,60 \% *$ \\
\hline
\end{tabular}

${ }^{*}$ signficante a $10 \%,{ }^{* *}$ significante a $5 \% \mathrm{e}^{* * *}$ signficantes a $1 \%$

Fonte: Autoria própria

Além disso, a fim de isolar completamente o efeito da crise, restringimos a amostra pós-boom de CDS até final de 2007, mais precisamente até 31/12/2007, e encontramos resultados bastante semelhantes aos apresentados anteriormente. $\mathrm{O}$ que sugere que a queda do impacto das mudanças de rating sobre os ativos financeiros iniciou-se antes da crise de 2008 e, portanto, não pode ser atribuída a mesma.

Tabela 13 - Isolando o efeito da crise de 2008

\begin{tabular}{cccccc} 
& \multicolumn{4}{c}{ Antes de 01/01/2003 } & De 01/01/2005 a 31/12/2007 \\
\hline \hline \multirow{2}{*}{ Moeda } & & up & down & up & down \\
& $\mathrm{CR}(0,+1)$ & $-0,40 \% * *$ & $2,00 \% * * *$ & $0.10 \%$ & $0.20 \%$ \\
& $\mathrm{CR}(-30,-1)$ & $0.10 \%$ & $5,10 \% * * *$ & $0.00 \%$ & $-0.30 \%$ \\
\hline \multirow{2}{*}{ Bolsa } & $\mathrm{CR}(0,+1)$ & $0.40 \%$ & $0.00 \%$ & $0.30 \%$ & $-1,10 \% * *$ \\
& $\mathrm{CR}(-30,-1)$ & $1.60 \%$ & $-7,30 \% * * *$ & $1.10 \%$ & $-1.10 \%$ \\
\hline
\end{tabular}

${ }^{*}$ signficante a $10 \%,{ }^{* *}$ significante a $5 \% \mathrm{e}^{* * *}$ signficantes a $1 \%$

Fonte: Autoria própria

\subsubsection{Outros ativos como controle}

A fim de verificar o poder do CDS em prever uma mudança de rating, utilizamos o movimento deste derivativo nos 30 dias que antecedem o evento como controle nas equações estimadas na subseção 1.5.3 e concluímos que isto faz o efeito do evento sobre o ativo analisado diminuir. $\mathrm{Na}$ presente subseção, testamos se ao colocarmos como controle a variação de outros ativos que não o CDS o efeito dos eventos sobre os ativos também se reduz ou se, de fato, o CDS desempenha um papel diferenciado como controle.

Desta forma, colocamos como controle a variação do câmbio nos últimos 30 dias que antecedem uma mudança de rating como controle em uma equação que mede o impacto do evento na bolsa de valores (equação 5), e vice-versa, isto é, utilizamos como controle a variação da bolsa nos 30 dias precedentes ao evento na equação que estima o efeito das mudanças de rating sobre a taxa de câmbio (equação 6). 


$$
\begin{aligned}
& C R_{\text {Bolsait }}=\propto+\beta_{1} \text { down }_{i t}+\beta_{2} u p_{i t}+\beta_{3} C R_{\text {Câmbioit }}(-30,-1)+\sum_{k} \beta_{k} X_{k}+\varepsilon_{i t} \\
& C R_{\text {Câmbioit }}=\propto+\beta_{1} \text { down }_{i t}+\beta_{2} u p_{i t}+\beta_{3} C R_{\text {Bolsait }}(-30,-1)+\sum_{k} \beta_{k} X_{k}+\varepsilon_{i t}
\end{aligned}
$$

Como se pode ver na tabela a seguir, quando utilizamos o movimento da bolsa (moeda) como controle na equação que regride a moeda (bolsa), a magnitude do efeito das mudanças de rating sobre os ativos se mantém exatamente a mesma e, apesar de uma ligeira redução na significância estatística em alguns casos, os efeitos ainda podem ser considerados significantes a $10 \%$ de nível de significância. Já quando utilizamos o CDS como controle, a magnitude dos efeitos muda completamente e todos, sem exceção, deixam de ser estatisticamente significantes a um nível de significância de 10\%. Portanto, o CDS exerce um efeito diferenciado quando utilizado como controle, o que significa que seu movimento nos

\begin{tabular}{|c|c|c|c|c|c|c|c|c|c|}
\hline \multicolumn{10}{|c|}{ Tabela 14 - Outros ativos como controle } \\
\hline & & \multicolumn{2}{|c|}{ Sem controle ${ }^{1}$} & \multicolumn{3}{|c|}{ Bolsa como controle ${ }^{4}$} & \multicolumn{3}{|c|}{ CDS como controle ${ }^{2}$} \\
\hline & & up & down & up & down & Bolsa & up & down & CDS \\
\hline \multirow{4}{*}{ Moeda } & $\mathrm{CR}(0,+1)$ & $0.01 \%$ & $0,20 \% * *$ & $0.00 \%$ & $0,20 \% *$ & $-0.30 \%$ & $0.05 \%$ & $-0.08 \%$ & $0.13 \%$ \\
\hline & $\mathrm{CR}(-30,-1)$ & $-0.11 \%$ & $1,00 \% * * *$ & $0.00 \%$ & $1,00 \% * *$ & $-3,90 \% * * *$ & $-0.50 \%$ & $-0.36 \%$ & $2,70 \% * * *$ \\
\hline & & \multicolumn{2}{|c|}{ Sem controle ${ }^{1}$} & \multicolumn{3}{|c|}{ Câmbio como controle ${ }^{3}$} & \multicolumn{3}{|c|}{ CDS como controle ${ }^{2}$} \\
\hline & & up & down & up & down & Moeda & up & down & CDS \\
\hline \multirow{2}{*}{ Bolsa } & $\mathrm{CR}(0,+1)$ & $0.01 \%$ & $-0,70 \% * * *$ & $0.00 \%$ & $-0,70 \% * * *$ & $0.10 \%$ & $0.09 \%$ & $-0.41 \%$ & $-0.11 \%$ \\
\hline & $\mathrm{CR}(-30,-1)$ & $1.00 \%$ & $-0.75 \%$ & $1.00 \%$ & $-0.50 \%$ & $-19,90 \% * * *$ & $0.10 \%$ & $0.19 \%$ & $-7,20 \% * * *$ \\
\hline
\end{tabular}
30 dias anteriores ao evento contém grande parte da informação fornecida pelo rating.

* signficante a $10 \%,{ }^{* *}$ significante a $5 \% \mathrm{e}{ }^{* * *}$ signficantes a $1 \%$

${ }^{1}$ referente à equação $(3) ;{ }^{2}$ referente à equação $(4) ;{ }^{3}$ referente à equação $(5) ;{ }^{4}$ referente à equação (6)

Fonte: Autoria própria

\subsubsection{Separação entre investment grade e não investment grade}

Pelos resultados anteriores constatamos que o efeito dos ratings sobre os ativos do mercado financeiro diminuiu de forma relevante nos últimos dez anos em comparação com os anos antecedentes e que este fato deve estar relacionado com a consolidação do mercado de CDS - ativo financeiro que, assim como as agências de risco, serve de indicador da qualidade do crédito de uma instituição ou país. Portanto, o papel informacional desempenhado pelos ratings deve ter sido absorvido pelo mercado de CDS, porém os ratings ainda possuem o papel de certificado para investimentos. Isto se deve ao fato de a legislação de diversos fundos de pensão ou outros investimentos mais conservadores proibirem a compra de ativos de países 
ou de companhias classificados como não investment grade por duas ou mais agências de risco. Este fato confere um poder de certificado aos ratings que não pode ser substituído pelo CDS.

Neste sentido, a fim de testar esta hipótese, nesta seção, iremos checar se os efeitos de mudanças de rating que fazem os países transitarem entre estes dois grandes grupos (grau de investimento e grau especulativo) são mais relevantes do que as demais mudanças.

A nomenclatura que utilizaremos é up ou down para eventos positivos e negativos, respectivamente, e as variáveis dummies upig e downig que assumem valor 1 nas respectivas ocorrências de um up que faz o país ganhar o investment grade e de um down que faz o país perder o investment grade. Assim, por exemplo, se um país for rebaixado e perder o investment grade, o efeito total do rebaixamento será a soma dos efeitos mostrados pelo down e pelo downig.

Tabela 15 - Mudança na classificação de investment grade

\begin{tabular}{|c|c|c|c|c|c|}
\hline & & up & down & upig & downig \\
\hline \multirow{2}{*}{ CDS } & $\mathrm{CR}(0,+1)$ & $-1,10 \% *$ & $4,60 \% * * *$ & $-4,40 \% *$ & $-0.20 \%$ \\
\hline & $C R(-30,-1)$ & $-4,30 \% * *$ & $10,00 \% * * *$ & $-3.00 \%$ & $8.40 \%$ \\
\hline \multirow{2}{*}{ Moeda } & $\mathrm{CR}(0,+1)$ & $-0.10 \%$ & $0,70 \% * * *$ & $-0.20 \%$ & $4,20 \% * * *$ \\
\hline & $\mathrm{CR}(-30,-1)$ & $-0.20 \%$ & $2,70 \% * * *$ & $-0.40 \%$ & $2.30 \%$ \\
\hline \multirow{2}{*}{ Bolsa } & $\mathrm{CR}(0,+1)$ & $0.30 \%$ & $-0,40 \% *$ & $-0.90 \%$ & $-2,00 \% * *$ \\
\hline & $C R(-30,-1)$ & $1,20 \% *$ & $-3,60 \% * * *$ & $-1.20 \%$ & $0.70 \%$ \\
\hline
\end{tabular}

Fonte: Autoria própria

A tabela anterior mostra alguns resultados interessantes. A variável $\mathrm{CR}(0,+1)$ mostra que, quando um país sofre um evento positivo que o torna grau de investimento, o CDS cai de maneira mais acentuada. Além disso, caso o país sofra um rebaixamento que tire o seu grau de investimento, a bolsa cai mais do que o usual e a moeda deprecia mais do que quando o rebaixamento não altera esta classificação do país.

Testamos se os resultados encontrados acima se mantêm após controlar as regressões pelo movimento do CDS durante os 30 dias que antecedem o evento. Isto é, para os ativos bolsa e câmbio, estimamos as mesmas regressões da Tabela 15, porém controlando pelo movimento do CDS nos 30 dias precedentes ao evento. Os resultados estão reportados na Tabela 16. 
Tabela 16 - Mudança na classificação de investment grade controlando pelo CDS

\begin{tabular}{ccccccc}
\hline & & up & down & upig & downig & CDS \\
\hline \multirow{2}{*}{ Moeda } & $\mathrm{CR}(0,+1)$ & $0,09 \%$ & $-0,19 \%$ & $-0,75 \%$ & $1,15 \% * *$ & $0,12 \%$ \\
& $\mathrm{CR}(-30,-1)$ & $-0,46 \%$ & $-0,22 \%$ & $-0,53 \%$ & $-1,32 \%$ & $2,7 \% * * *$ \\
\hline \multirow{2}{*}{ Bolsa } & $\mathrm{CR}(0,+1)$ & $0,05 \%$ & $-0,31 \%$ & $0,5 \%$ & $-0,9 \%$ & $-0,1 \%$ \\
& $\mathrm{CR}(-30,-1)$ & $-0,14 \%$ & $-0,19 \%$ & $3,35 \%$ & $3,77 \%$ & $-7,26 \% * * *$ \\
\hline
\end{tabular}

* signficante a $10 \%,{ }^{* \star}$ significante a $5 \% \mathrm{e}^{* * *}$ signficantes a $1 \%$

Fonte: Autoria própria

Assim como os resultados reportados na Tabela 9, após controlar pelo CDS, o efeito de uma reclassificação de rating sobre os ativos bolsa e câmbio some completamente, exceto pelo efeito no ativo câmbio de um downgrade que retira a classificação de investment grade do país. Neste caso, mesmo controlando-se pelo CDS, a moeda do país que perde seu grau de investimento deprecia no momento do anuncio $1,15 \%$, isso a 5\% de nível de significância.

Estes resultados reforçam a importância do papel de certificadoras exercido pelas agências de rating e, portanto, limita o poder do CDS de substituir os ratings.

\subsection{CONCLUSÃO}

Este ensaio visou estudar a relação entre o ativo CDS e os ratings soberanos atribuídos pela $S \& P$. Nossa hipótese básica de trabalho foi que este novo instrumento de aferição da qualidade do crédito de uma instituição ou de um país diminuiu a relevância do efeito que os ratings, os quais são atribuídos por agências de risco, têm sobre o mercado. O CDS deveria antecipar fortemente os movimentos de mudança de rating, o que no limite levaria os ativos financeiros a não apresentarem nenhuma reação a reclassificações desta natureza. Isto se daria pelo fato de o CDS ser um ativo financeiro e, portanto, seguir um desenho de incentivo para que o preço reflita da maneira mais fidedigna possível a qualidade do crédito do ativo analisado e, ainda, por ser uma variável contínua no tempo - incorporando a cada segundo as novas crenças e informações ao preço.

De fato, encontramos que o poder de impactar os mercados pela $S \& P$ diminuiu nos últimos dez anos, coincidindo com o período de consolidação do mercado de CDS. Além disso, analisamos os impactos de mudanças de rating sobre o mercado controlando as regressões pelo CDS e encontramos que o poder explicativo dos ratings desaparece. Verificamos, também, que este resultado não se repete quando utilizamos outros ativos que não o CDS como controle. 
Sendo assim, o desenvolvimento do mercado de CDS permanece como forte candidato a explicar a redução da relevância dos ratings nos mercados financeiros na última década.

Vale notar que também encontramos resultados que corroboram a visão de que a sinergia entre o mercado de CDS e o papel dos ratings é grande, dado que o mercado de CDS é o que mais reage a reclassificações de risco efetuadas pela $S \& P$. Ao mesmo tempo, este resultado ressalta que as agências de rating ainda têm papel relevante no mercado financeiro oriundo de uma expertise melhor do que a do mercado em classificar a qualidade do crédito de uma instituição e/ou pelo fato de terem acesso a informações não públicas, ou ainda, por exercerem, mesmo que apenas por convenção, um papel importante na tomada de decisão dos investidores institucionais. 


\section{CUSTOS DE ENTRADA PARA EXPORTAÇÃO COMO FONTE DE COMPETITIVIDADE.}

\subsection{INTRODUÇÃO}

A literatura sobre comércio internacional afirma que as firmas incorrem em custos fixos de entrada ao começarem a exportar. Certificados de qualidade com reconhecimento internacional, adaptação da embalagem às regras do país importador, conhecimento das leis de comércio e formação de networking dentro do país importador são alguns exemplos de possíveis custos de entrada que uma firma se depara ao iniciar sua atividade exportadora.

Diversos trabalhos encontraram evidências de que os custos de entrada para exportação são relevantes em alguns setores de países como Colômbia, Peru, EUA, Brasil e Argentina. Contudo, usualmente, os custos fixos de entrada para exportação são estimados apenas para um único país e/ou para poucos setores da economia, o que pode gerar desconfiança de que são singularidades do país ou do setor analisado. Neste sentido, nossa primeira contribuição para a literatura foi encontrar evidências de que o custo de entrada para a exportação, na média, existe para uma ampla gama de setores e para mais de 120 países em desenvolvimento.

Utilizamos para isto o banco de dados do World Bank Enterprise Survey do Banco Mundial, o qual foi construído através de uma pesquisa realizada por esta instituição com mais de 70 mil firmas atuantes em mais de 120 países em desenvolvimento. Aplicamos, com adaptações, a metodologia presente em Bernard e Jensen (2004) aos nossos dados e encontramos que a experiência prévia com exportação aumenta consideravelmente a probabilidade de a firma exportar no presente, o que é considerado uma evidência da existência de custos de entrada para a exportação. Além disso, estimamos, com adaptações, o modelo de exportação de Das, Roberts e Tybout (2007) e encontramos que, em média, as firmas desembolsam US\$3,2 milhões para começar a exportar.

Nossa segunda, e talvez mais importante, contribuição para a literatura foi mostrar que o custo fixo de entrada para exportação difere entre os países. Apesar de ser um custo único, o qual a firma paga apenas na primeira exportação, seu valor, conforme encontrado por nós, é relevante, o que pode ser decisivo na escolha da firma ser exportadora ou não. Portanto, o diferencial sobre o custo fixo de entrada para a exportação entre os países é mais um fator de competitividade internacional.

Mas quão relevante é o diferencial dos custos fixos de entrada para exportação para a competitividade dos países? Para trazer luz a este debate calculamos a correlação entre estes 
custos fixos dos países e os coeficientes das dummies de países na regressão que mede a probabilidade de uma firma ser exportadora. O resultado deste exercício mostra que estas variáveis são inversamente proporcionais, ou seja, quanto maior o custo de entrada para exportação de um país, menor é a probabilidade de uma firma localizada neste país ser exportadora. Portanto, a diferença de custo fixo de entrada para exportação entre os países pode, na margem, explicar porque que firmas muitos parecidas localizadas em países distintos adotam decisões opostas com relação à atividade exportadora.

Por fim, como um último exercício, traçamos correlações entre os custos fixos de entrada de cada país com a qualidade das várias instituições dos mesmos. Tal exercício é motivado por acreditarmos que, além dos fatores concretos já citados acima, outros elementos também podem estar relacionados com o custo de entrada para a exportação. Tais elementos são: a regulação aduaneira e as leis de comércio, o funcionamento do sistema jurídico que determina o grau de cumprimento aos contratos firmados, a instabilidade política do país, a concorrência com o setor informal, o nível de corrupção do país e as leis trabalhistas. Vale notar que na literatura há um consenso de que instituições de melhor qualidade, sejam estas referentes ao cumprimento dos contratos (sistema jurídico) ou ao grau de flexibilidade do mercado de trabalho, são fontes de vantagens comparativas no comércio internacional. Neste sentido, iremos trazer alguma luz ao debate sobre a relação entre o custo fixo de entrada para exportação e as diversas variáveis institucionais.

O ensaio será apresentado da seguinte forma. Na subseção 2.2 temos um apanhado da literatura correlata. Na subseção 2.3, discutimos a metodologia empregada no trabalho, assim como o modelo econômico que pauta a análise. Na subseção 2.4 discorremos sobre os dados, detalhando as variáveis do banco de dados do World Bank Enterprise Survey e das variáveis agregadas para país, ambas retiradas do Banco Mundial. Na subseção 2.5 mostramos os resultados e, finalmente, na seção 2.6, concluímos o ensaio.

\subsection{REVISÃO DE LITERATURA}

A literatura na qual este ensaio se apoia aquiesce que as firmas enfrentam um custo de entrada significante para começarem a exportar. Dixit (1989) e Krugman (1980) foram os mais relevantes precursores destes estudos. Estes autores afirmam que as firmas não exportadoras incorrem em custos de entrada ao introduzirem seus produtos no mercado internacional, fazendo com que a oferta de exportação no período presente seja dependente do número e do tipo de produtores que exportaram no período anterior. 
Em termos teóricos, Melitz (2003) constrói um modelo que descreve que, diante da existência de custos de entrada para exportação, apenas as firmas mais produtivas exportam, pois são as únicas capazes de arcar com este dispêndio. Consequentemente, na presença de comércio, apenas as firmas mais eficientes se beneficiam, na forma de aumento de lucros e de market share. Já as menos eficientes têm o lucro e o market share reduzidos e, ainda, as menos eficientes são forçadas a abandonar o mercado. Desta forma, conclui-se que o país exposto ao comércio obtém ganhos líquidos de bem-estar, pois a produtividade agregada da indústria aumenta, mesmo que a produtividade das firmas em nível individual se mantenha inalterada.

Já os estudos empíricos, no geral, utilizam modelos de escolha discreta e mostram que as firmas exportadoras são mais produtivas, são mais velhas e maiores, são interligadas a outras plantas, pertencem a estrangeiros, etc. Além disso, estes estudos encontram fortes evidências da existência de custos fixos de entrada para a exportação, no sentido de que a experiência anterior com a exportação aumenta consideravelmente a probabilidade de a firma exportar no presente.

Nesta linha destacam-se trabalhos como de Bernard e Jensen (2004) que, utilizando dados dos Estados Unidos contendo 13.550 plantas industriais no período de 1984 a 1992 , encontram que os custos de entrada para a exportação são significativos neste país e que as características individuais de cada firma são também importantes para explicar a decisão de entrada no mercado internacional. Vale notar que, em trabalhos anteriores, estes mesmos autores constataram que as firmas exportadoras são geralmente maiores, possuem um maior número de trabalhadores, têm proporcionalmente mais trabalhadores com cargo de gerência, pagam altos salários, têm maior produtividade, fazem uso mais intensivo de tecnologia e são, normalmente, parte de uma firma detentora de várias plantas.

Roberts e Tybout (1997) desenvolveram um modelo de escolha dinâmico sobre o comportamento da firma exportadora separando o efeito no lucro devido à heterogeneidade das firmas e aos custos de entrada. Estes autores analisaram os quatro maiores segmentos industriais exportadores da Colômbia durante o período de 1981-1989 e encontram que os custos de entrada são relevantes e estatisticamente significantes. Coerentemente com este resultado, os autores encontram que a experiência de uma exportação prévia aumenta a probabilidade de que a firma exporte no período presente. Além disso, os autores também encontraram que plantas grandes, antigas e pertencentes a corporações são mais propensas a exportar que o restante das outras firmas. 
Freund e Pierola (2010) analisaram dados de exportação da agricultura não tradicional do Peru sob o arcabouço de que há incerteza com relação à lucratividade da exportação e aos custos de entrada. As autoras encontraram resultados consistentes com trabalhos anteriores, como o fato de as firmas maiores e de melhor qualidade serem as que decidem adentrar mais cedo em outros mercados e/ou com novos produtos, e também serem as que possuem maior taxa de sobrevivência no segmento exportador. Além disso, encontraram diferenças significativas na decisão de entrada para exportação das firmas conforme o mercado e o tipo de produto. Para a entrada com produtos já exportados e para mercados já explorados, o custo fixo é baixo. Firmas que decidem exportar para novos mercados produtos antigos enfrentam custos de entrada maiores, todavia não excessivos. Já firmas que decidem exportar novos produtos enfrentam custos fixos muito elevados. Contudo, na média, encontram indícios de que os custos de entrada não são tão altos no Peru.

Albornoz, Pardo, Corcos e Ornelas (2012) argumentam que diante da existência de custos fixos de entrada no mercado internacional, as firmas atuam de forma "estratégica". Primeiramente, uma firma inicia a atividade exportadora em pequenas quantidades cujos destinos são os países vizinhos. Caso obtenha sucesso, a firma passa a exportar quantidades maiores e para um grupo maior de países. A exportação inicial, pequena e direcionada à vizinhança, funciona como um teste sobre a capacidade de a firma ser uma exportadora. Estes pressupostos são confirmados pelos exercícios realizados com os dados de exportação da Argentina.

Em Arkolakis, Ganapati e Muendler (2014), os autores desenvolvem um modelo de equilíbrio de firmas com multiprodutos no mercado internacional a fim de quantificar o custo de acesso aos mercados no nível da firma, de seus produtos e de seus destinos. O modelo adota três tipos de custo: (1) o custo de produção específico de um determinado produto no nível da firma, (2) custos de iceberg e (3) o custo fixo de exportação que pode, dentre outras coisas, capturar barreiras não tarifárias para acessar os mercados. Os autores, utilizando dados do Brasil, encontram evidências de existência de economias de escala em relação aos custos de se acessar os mercados. Porém, por outro lado, a exportação de produtos adicionais que estão longe do núcleo de competência da empresa faz esta incorrer em custos unitários, fazendo a firma enfrentar deseconomias de escala no resultado líquido.

Na mesma linha de pesquisa dos trabalhos citados acima, podemos mencionar também os estudos de Clerides, Lach e Tybout (1998) que utilizam dados de firmas da Colômbia, México e Marrocos, Aitken, Hanson e Harrison (1997) que usam dados de empresas do 
México e Fakih e Ghazalian (2013) que analisam empresas do Oriente Médio e Norte da África.

Neste ensaio, utilizando uma amostra de firmas de 123 países em desenvolvimento, estimamos modelos semelhantes aos desses estudos e encontramos resultados parecidos. Isto é, para a média destes 123 países, encontramos que a heterogeneidade das firmas desempenha um papel relevante em determinar se ela será exportadora ou não e que há um custo fixo associado ao início da atividade exportadora. Além disso, mostramos que pertencer a determinado país pode aumentar ou diminuir a probabilidade de uma firma ser exportadora.

Ainda com o intuito de estudar os determinantes da escolha das firmas em exportar ou não (embora empregando métodos bastante distintos dos demais estudos) Das, Roberts e Tybout (2007) constroem um modelo estrutural dinâmico que possibilita estimar em valor o custo de entrada para a exportação. Estes autores aplicam este modelo a dados de três setores industriais da Colômbia e encontram que o custo de entrada para a exportação neste país e nestes setores é de em média 400 mil dólares. Este trabalho servirá de referência para calcularmos em dólares o custo médio de entrada enfrentado pelas firmas dos 123 países presentes em nossa amostra, bem como para calcular este custo por país.

Logo, nosso ensaio contribui com esta literatura ao encontrar evidências de que o custo fixo de entrada para a exportação não é uma particularidade de um país e/ou setor de atividade, visto que encontramos um valor elevado e estatisticamente significante para a média das firmas dos países em desenvolvimento. Além disso, encontramos evidências de que o custo fixo de entrada para exportação pode variar entre os países e que esta variabilidade pode ajudar a explicar a significância das dummies de países na regressão da probabilidade de a firma ser ou não exportadora. Em outras palavras, esta variabilidade pode ajudar a explicar a influência das características do país onde a firma está localizada sobre a probabilidade de esta firma ser ou não exportadora.

Além da bibliografia de custo de entrada para a exportação, nosso estudo se relaciona também com a literatura de qualidade de instituições e comércio, uma vez que um dos nossos objetivos é relacionar os custos de entrada para a exportação com a qualidade das instituições de cada país.

Desta forma, podemos destacar sobre esta literatura trabalhos como o de Greif (1993), que analisa a existência de agentes facilitadores do comércio durante o século XI que surgiram em resposta ao problema de cumprimento dos contratos em mercados como o de Maghribi devido à ausência de um sistema legal oficial. Os comerciantes de Maghribi operavam através de agentes no exterior que facilitavam as operações comerciais, diminuindo 
o risco no cumprimento dos contratos e permitindo que os comerciantes se tornassem sedentários. O autor modela esta relação através da teoria de jogos repetidos, onde a credibilidade na lealdade do agente é garantida pela punição coletiva, pelo salário eficiência e pela expectativa de ganhos com contratações futuras com outros comerciantes. $\mathrm{O}$ autor afirma que a existência deste mecanismo entre agentes e comerciantes reflete a dependência das instituições pelo comércio.

Levchenko (2006) desenvolve um modelo teórico sobre comércio onde as instituições, aqui definidas como a qualidade dos contratos, direitos de propriedade e proteção aos acionistas, são modeladas em um arcabouço de contratos incompletos. O autor encontra que, quando um país que é superior institucionalmente se abre para o comércio, ele irá exportar mais o bem que é intensivo em instituições. Este resultado encontrado no modelo teórico é testado empiricamente com dados de importação dos EUA de 116 países e 389 indústrias no ano de 1998. O autor conclui, portanto, que a qualidade das instituições é uma fonte de vantagem comparativa, o que implica que os países mais pobres (no trabalho nomeados como os do sul) podem não ter ganhos com a abertura comercial. Nunn (2007) obtém resultados muito semelhantes. Com dados de diversos países, conclui que países com instituições de boa qualidade se especializam em indústrias mais intensivas em instituições. Além disso, mostra que a qualidade das instituições explica mais do padrão do comércio que os estoques de capital físico e humano do país.

Neste mesmo arcabouço, Acemoglu, Antràs e Helpman (2007) desenvolvem um modelo teórico para a relação entre a decisão das firmas em adotar certo padrão de tecnologia e os contratos incompletos. Assumem que a tecnologia é tão melhor quanto maior for a quantidade de diferentes insumos (produtos intermediários) utilizados pelas firmas. Todavia, a maior abrangência de insumos exige um maior número de contratos com os fornecedores, que por sua vez implica em um maior risco em virtude dos contratos incompletos. Os autores consideram que a aplicação mais interessante desta modelagem é para o comércio internacional, pois encontram que em um contexto de economia aberta a diferença na qualidade dos contratos gera uma vantagem comparativa endógena. Isto é, os países com melhores instituições possuem uma vantagem comparativa em setores mais dependentes de contratos, em linha com os resultados encontrados por Nunn (2007) e Levchenko (2006).

Araujo, Mion e Ornelas (2016) desenvolvem um modelo que descreve como as firmas constroem reputação para enfrentar os problemas de cumprimento dos contratos internacionais. Estes autores encontram que os exportadores começam suas atividades com um volume maior e permanecem por um tempo mais longo como tais em países com 
instituições de melhor qualidade. Além disso, testam empiricamente seus resultados utilizando dados de exportação da Bélgica entre 1995 e 2008 e encontram que a qualidade das instituições em relação a contratos extrapola o papel de custos fixos de exportação da firma, pois também afetam a dinâmica de exportação das empresas ao afetar o custo marginal de exportação.

Neste mesmo sentido, Anderson e Marcouiller (2002) desenvolveram um modelo no qual a probabilidade de perda de produto em função da baixa qualidade das instituições funciona como um imposto oculto na transação comercial. Notam que instituições de baixa qualidade contraem o comércio internacional do mesmo modo que um imposto. Neste sentido, os autores conseguem explicar porque países parecidos e com boas instituições comercializam mais entre si do que com países diferentes que possuem instituições inadequadas (contrariando a teoria de que o comércio entre países diferentes tem um maior potencial de ganhos).

Outros trabalhos inserem o problema de cumprimento de contratos no comércio internacional dentro da dinâmica do mercado de trabalho. Costinot (2009) desenvolve um modelo que tenta explicar a origem das vantagens comparativas entre os países através da qualidade das instituições e da qualidade do estoque de mão-de-obra de cada país. Neste modelo, a qualidade das instituições é tratada como um problema de contratos incompletos, o qual está presente dentro do mercado de trabalho de cada país e não dentro das relações comerciais. Em outras palavras, o trabalhador pode não cumprir seu contrato de trabalho, o qual estipula suas tarefas. Neste modelo, a produção do bem complexo em relação ao simples possui uma quantidade maior de tarefas e uma maior divisão do trabalho, consequentemente, uma dependência maior do cumprimento dos contratos de trabalho. O autor conclui que melhores instituições e maiores níveis de educação são fontes complementares de vantagens comparativas em indústrias mais complexas.

Aeberhardt, Buono e Fadinger (2012) analisam as relações entre as transações comerciais e a qualidade das instituições do país importador na ausência de custo fixos de entrada para a exportação. Os autores concluem que a dependência do estado, aqui definido como o efeito de uma firma ter exportado para um determinado destino no ano anterior sobre a probabilidade desta firma exportar para este mesmo destino no ano corrente, é maior e a taxa de descumprimento dos contratos é menor em países com melhores instituições. Desta forma, a existência de contratos incompletos gera histereses na decisão de exportar, mesmo na ausência de custos fixos de entrada. Além disso, demonstram que o impacto da qualidade das instituições sobre a dependência do estado e a taxa de descumprimento de contratos é maior 
em setores que estão mais expostos a estes problemas. Exercícios com dados de exportação de manufaturas francesas entre 1993 e 2005 confirmam estes resultados.

Há uma vasta literatura sobre qualidade das instituições do mercado de trabalho e comércio internacional, mas com foco não em qualidade de cumprimento dos contratos e sim em grau de flexibilidade das leis trabalhistas.

Em termos teóricos, se destacam trabalhos como de Donald Davis (1998) que constrói um modelo onde o mundo se divide entre EUA com salários flexíveis e a Europa com a política de salário mínimo. Na autarquia, na Europa há desemprego em função da política de salário mínimo e nos EUA não há desemprego porque o salário real pode cair a ponto de empregar toda a população. No momento em que estes blocos passam a fazer comércio entre si, a taxa de desemprego na Europa dobra, surgem desempregados nos EUA (embora em quantidade muito inferior ao encontrado na Europa) e os salários dos americanos sobem. Portanto, o comércio internacional força os europeus a incorrerem em um desemprego maior não só para sustentar seus maiores salários como também para sustentar os maiores salários dos americanos. Diante destes resultados, o autor conclui que mesmo quando o mercado de fatores é estritamente local, em presença de comércio, as instituições que vigoram apenas em nível nacional afetam o padrão global de alocação.

Nesta mesma direção, ainda em termos teóricos, Helpman e Itskhoki (2010) constroem um modelo de comércio internacional de dois países e dois setores, sendo que um dos setores produz um produto homogêneo enquanto que o outro setor produz produtos diferenciados. Os países são exatamente iguais exceto pelas leis trabalhistas como custo de férias, custos de demissão, seguro-desemprego etc. Os autores mostram que ambos os países obtêm ganhos com o comércio, porém o país com regras trabalhistas mais flexíveis ganha proporcionalmente mais que o país com regras mais rígidas. Portanto, um mercado de trabalho flexível gera uma vantagem comparativa para o país, com uma parcela maior de firmas exportadoras e uma maior quantidade de produtos diferenciados na sua pauta de exportação em relação ao país com leis trabalhistas mais rígidas.

Com comprovação empírica, se destacam trabalhados como de Cuñat e Merlitz (2007) que constroem um modelo de comércio entre dois países, sendo um com leis trabalhistas flexíveis e o outro com leis trabalhistas rígidas. Neste modelo, na presença de choques, o produtor final do país com leis trabalhistas mais flexíveis pode realocar sua produção de forma a utilizar mais os produtos intermediários que ficaram mais produtivos depois do choque; isto não se aplica para o país com leis trabalhistas mais rígidas. Este comportamento confere ao país com leis trabalhistas mais flexíveis, em relação ao país com leis trabalhistas 
rígidas, uma vantagem comparativa, a qual é maior quanto maior for a volatilidade da indústria. Os autores testam empiricamente este modelo e, de fato, encontram que os países com leis trabalhistas mais flexíveis concentram suas exportações relativamente mais em setores mais voláteis.

\subsection{METODOLOGIA}

Como um primeiro exercício, em linha com a literatura existente sobre o tema, estimamos, através de um modelo de escolha discreta (probit), a decisão de a firma ser ou não exportadora. Analisamos se caraterísticas privadas das firmas, inclusive a experiência anterior com exportação, influenciam nesta decisão e, caso positivo, como isso ocorre.

Em um segundo momento, a fim de estimar o custo de entrada para a exportação em valor monetário, apoiaremo-nos no modelo de oferta de exportação adotado em Das, Roberts e Tybout (2007), porém com algumas adaptações. Este modelo é baseado nas seguintes hipóteses: (1) os mercados domésticos e externos dos produtos são baseados na concorrência monopolística e são segmentados um do outro, o que garante que as firmas operem na parte negativamente inclinada da receita marginal em cada mercado; (2) os custos marginais não respondem a choques no produto, o que garante que os choques na demanda doméstica não afetem o nível ótimo de exportação, nos permitindo focar apenas no mercado exportador; (3) os produtores são heterogêneos em termos de custo marginal de produção e de demanda externa dos seus produtos, consequentemente o lucro varia entre os produtores; (4) as firmas precisam pagar custos de entrada para iniciar a atividade exportadora.

Iniciamos caracterizando o lucro potencial com exportação da firma $i$ uma vez que esta tenha adentrado o comércio internacional. A magnitude deste lucro depende de fatores que afetem o custo marginal, como variação de preços, e de fatores que afetem a demanda externa, como o câmbio real. Assumimos que o custo marginal e a demanda externa seguem uma função Cobb-Douglas nestes fatores, assim o lucro potencial bruto das exportações é função log-linear do conjunto destas variáveis:

(1) $\ln \left(\pi_{i t}^{*}\right)=\varphi_{0} z_{i t}+\varphi_{1} x_{t}+v_{i t}$

Onde $\pi_{i t}^{*}$ é o lucro potencial bruto da firma $i$ com as exportações no período t; $z_{i t}$ é um vetor de características da firma; $x_{t}$ é um vetor de variáveis macroeconômicas do país; e $v_{i t}$ é o resíduo normalmente distribuído. 
Assim como em Das, Roberts e Tybout (2007), o nosso banco de dados apenas nos informa a receita com exportação (parcela da produção destinada à exportação multiplicada pela receita total) e não o lucro gerado com a exportação. Para lidar com esta restrição nós utilizaremos a relação entre lucro e receita dada pela função de maximização de lucros, como em Das, Roberts e Tybout (2007).

O preço doméstico das exportações $\left(P_{i t}^{f}\right)$ é relacionado com o custo marginal de produção $\left(c_{i t}\right)$ através da equação $P_{i t}^{f}\left(1-n_{i}^{-1}\right)=c_{i t}$, onde $n_{i}>1$ é a elasticidade da demanda externa específica à firma $i$. Multiplicando ambos os lados pelo mark-up padrão da equação de maximização de lucros da quantidade de vendas externas obtemos a seguinte equação $R_{i t}^{f^{*}}\left(1-n_{i}^{-1}\right)=C_{i t}^{f^{*}}$, onde $R_{i t}^{f^{*}}$ e $C_{i t}^{f^{*}}$ são as receitas potenciais com as exportações e os custos potenciais com as exportações, respectivamente. Rearranjando, temos:

(2) $\pi_{i t}^{*}=R_{i t}^{f^{*}}-C_{i t}^{f^{*}}=n_{i}^{-1} R_{i t}^{f^{*}}$

Substituindo (2) em (1), temos que:

(3) $\ln \left(R_{i t}^{f^{*}}\right)=\ln n_{i}+\varphi_{0} z_{i t}+\varphi_{1} x_{t}+v_{i t}$

$\mathrm{Na}$ equação (3) outro problema aparece. A elasticidade da demanda externa a cada firma precisará ser estimada. Para lidar com este novo problema, seguindo Das, Roberts e Tybout (2007), nós assumimos que a razão entre a elasticidade da demanda externa pela elasticidade da demanda doméstica é $(1+v)$ para todos os produtores dentro da indústria. Isto implica que o custo total de produção da firma $i$ é $C_{i t}=C_{i t}^{f}+C_{i t}^{d}=R_{i t}^{f}\left(1-n_{i}^{-1}\right)+$ $R_{i t}^{d}\left(1-n_{i}^{-1} \cdot(1+v)\right)$, onde $R_{i t}^{d}$ é a receita das vendas domésticas e $C_{i t}^{d}$ é o custo com as vendas domésticas. Rearranjando, temos que:

$$
\text { (4) } n_{i}=\frac{\left(1+v R_{i t}^{d} / R_{i t}\right)}{\left(1-C{ } / R_{i t}\right)}
$$


Onde $R_{i t}=R_{i t}^{d}+R_{i t}^{f}$ é a receita total e $(1+v) \sim U(0,15)^{13}$.

Por causa do logaritmo na equação (1), o lucro potencial com exportação é sempre positivo. Porém, há firmas que decidem não exportar. Neste sentido a regra de participação no mercado exportador pode ser obtida pela maximização de $\mathrm{U}($.$) , onde \gamma_{1}$ representa o custo fixo de entrada para a exportação, $y_{i t}$ é igual a 1 se a firma $i$ exporta no período $t$ e zero caso contrário, e de forma similar, $y_{i t-1}$ é igual a 1 se a firma $i$ exportou no passado e zero caso contrário. Consequentemente, a firma apenas exporta se o lucro potencial com a exportação for maior que zero, e quando ela inicia a atividade exportadora, ou seja, quando $y_{i t}=$ 1 e $y_{i t-1}=0$, ela incorre em um custo extra, $\gamma_{1}$, que é o custo fixo de entrada para exportação.

(5) U(.) $\left\{\begin{array}{cl}\pi_{i t}^{*}\left(z_{i t}, x_{t}\right)+\varepsilon_{1 i t} & \text {, se } y_{i t}=1 \text { e } y_{i t-1}=1 \\ \pi_{i t}^{*}\left(z_{i t}, x_{t}\right)-\gamma_{1}+\varepsilon_{2 i t} & \text {, se } y_{i t}=1 \text { e } y_{i t-1}=0 \\ 0 & \text {, se } y_{i t}=0\end{array}\right.$

Juntando as duas primeiras equações de (5) obtemos a equação (6), que será utilizada para estimar o custo fixo de entrada para a exportação.

(6) $\ln \left(R_{i t}^{f^{*}}\right)=\ln n_{i}+\varphi_{0} z_{i t}+\varphi_{1} x_{t}-\gamma_{1} I\left(y_{i t}=1\right.$ e $\left.y_{i t-1}=0\right)+\vartheta_{1 i t}$

Neste modelo $z_{i t}$ é o vetor de características da firma $i$, que será composto por estado legal da firma (por exemplo, se é cotada em bolsa de valores ou é de capital fechado), quantidade de trabalhadores em tempo integral, salário médio dos trabalhadores, idade da firma e porcentagem da firma pertencente ao governo e a estrangeiros. Já o vetor $x_{t}$ que contém características do país exportador, será composto pelo câmbio real PPP referente ao ano anterior e ao ano corrente. E, finalmente, $I\left(y_{i t}=1\right.$ e $\left.y_{i t-1}=0\right)$ é uma função indicador

\footnotetext{
${ }^{13}$ No nosso modelo utilizaremos $(1+v) \sim U(0,15)$, pois desta forma garante-se que $n_{i}>0$, condição indispensável ao funcionamento do modelo, e que os valores de $n_{i}$ sejam consistentes com a literatura. Das, Robert e Tybout (2007) utilizam $(1+v) \sim U(0,2)$ para que a média seja 12 com desvio padrão de 16 . Yi (2003) afirma que as elasticidades da demanda de exportação devem se situar ao redor de 12 e 13 para que haja consistência com o crescimento das exportações globais e as reduções de barreiras ao comércio no contexto de modelos de comércio estáticos. Goldberg e Knetter (2009) estimam que a elasticidade da demanda externa a alguns produtos da Alemanha e dos EUA tem média 16 e desvio padrão 26. No nosso trabalho a elasticidade da demanda externa tem média 18,1, desvio padrão de 18,6 e mediana 12,3.
} 
que assume valor 1 se a firma exporta no período $t$ e não exportava no passado, e zero se exporta em $t$ e no passado. Desta forma, $\gamma_{1}$ está associado com os custos de entrada para exportar.

A estimação da equação (6) por Mínimos Quadrados Ordinários apresentaria um problema de viés de seleção, uma vez que a equação (6) representa apenas as duas primeiras equações de (5) e, portanto, desconsidera o fato de existirem firmas que preferem ficar fora do mercado internacional. A fim de corrigir este viés, assim como em Das, Roberts e Tybout (2007), estimamos a equação (6) utilizando o método de Tobit tipo II, chamado também de método de Heckman.

Este método é composto de duas etapas. A primeira delas irá estimar a equação de seleção, a qual calculará a probabilidade de uma firma ser exportadora ou não. Para que o modelo seja corretamente identificado, utilizamos na estimação da equação de seleção, além de variáveis independentes usadas para explicar a receita com exportação, também variáveis do país em que a firma está localizada, como a língua e a disposição de saída para o mar ${ }^{14}$. Acreditamos que o fato da firma pertencer a um país que tenha saída para o mar e onde a língua oficial seja o inglês ou o francês influencie na decisão da firma ser exportadora. Primeiramente, um país com saída para o mar ou que foi ex-colônia de um outro país deve ser culturalmente mais voltado para fora. Além disso, a presença destas características deve facilitar de alguma forma a atividade exportadora do país, pois o deixa mais "perto" do mercado consumidor. Isto se explica pelo fato de que no mundo há mais países que falam inglês ou francês ${ }^{15}$ do que outras línguas e porque o fato de possuir saída para o mar seria de alguma forma equivalente a fazer fronteira com outros países ${ }^{16}$.

A segunda etapa do método estima a equação (6) corrigindo-a pela razão de Mills, ou seja, corrigindo pelo viés de seleção.

Assim, utilizando a amostra completa, estimamos se existe um custo fixo médio de entrada para exportação em termos globais, ou mais precisamente, se existe um custo fixo de entrada para exportação nos países em desenvolvimento. Além disso, interagimos a variável

\footnotetext{
${ }^{14}$ Vale notar que variáveis geográficas ou culturais afetam o padrão de comércio conforme mostraram Eaton e Kortum (2002).

${ }^{15}$ No mundo, há 29 países que falam francês e 24 países que falam inglês.

${ }^{16}$ É importante destacar que estas variáveis geográficas ou culturais podem afetar o custo, porém não a receita com exportação que é a variável dependente no nosso modelo. Analogamente, Araújo, Mion e Ornelas (2016), argumentam que suas variáveis instrumentais ditas "extended gravity", onde proximidade é medida em termos de distância geográfica e cultural entre os países, afetam diretamente a decisão de entrada e sobrevivência da firma em um novo destino das vendas, porém não afetam o valor inicial da exportação e nem seu crescimento, o que reforça nossa hipótese.
} 
$I\left(y_{i t}=1\right.$ e $\left.y_{i t-1}=0\right)$ com as variáveis dummies de país a fim de estimar o custo fixo de entrada para exportação para cada país da nossa amostra.

Em seguida, de posse destes custos fixos de entrada para cada país, fizemos exercícios de correlação. Primeiramente, relacionamo-los com os coeficientes das dummies de países na estimação da probabilidade de uma firma ser exportadora. O que motivou tal exercício é que acreditamos que quando um país tem um elevado custo fixo de entrada para exportação, as firmas localizadas neste país apresentam uma probabilidade menor de serem exportadoras.

Posteriormente, fizemos correlações entre o custo fixo de entrada para a exportação dos países e as variáveis institucionais dos mesmos a fim de encontrar alguma evidência de que a qualidade das instituições afeta o custo fixo de entrada para exportação, de modo que, quanto pior a qualidade da instituição maior o custo de entrada para exportação. As instituições analisadas foram: regulação aduaneira e as leis de comércio, dificuldade na obtenção de licenças e permissões, funcionamento do sistema jurídico, instabilidade política do país, concorrência com o setor informal, nível de corrupção do país e leis trabalhistas.

\subsection{DADOS}

Em relação aos dados, utilizamos a base de dados da World Bank Enterprise Survey construída através de uma pesquisa realizada pelo Banco Mundial ${ }^{17}$ com firmas atuantes em países em desenvolvimento. Nesta pesquisa, que dentre outros aspectos adota um tamanho de amostra grande o suficiente para produzir análises estatísticas robustas com um nível de precisão mínimo de $7,5 \%$ em um intervalo de confiança de $90 \%{ }^{18}$, há um questionário muito amplo. Neste questionário as firmas informam o setor em que atuam, o tamanho da firma, como é a estrutura proprietária da firma, a formação do gerente, a quantidade das vendas totais da firma no ano fiscal, o quanto da produção é exportado e o quanto é direcionado para o mercado interno, quantos competidores a firma tem, se a firma recebe subsídio do governo, se a firma utiliza alguma tecnologia importada, se a firma passou por algum processo de inovação, quais os problemas de infraestrutura enfrentados pela firma, se a firma obtém crédito de maneira fácil, quem fornece crédito para a firma, se o país que a firma está instalada possui regras e leis que facilitam a atividade da firma etc. Esta pesquisa é anual e

\footnotetext{
${ }^{17}$ Enterprise survey, http://www.enterprisesurveys.org, World Bank.

${ }^{18}$ Para mais informações, consulte:

http://www.enterprisesurveys.org/ /media/GIAWB/EnterpriseSurveys/Documents/Methodology/Sampling_Note .pdf
} 
compreende os anos de 2006 a 2013. Neste interim, há 123 países pesquisados, perfazendo um total de 76.408 firmas entrevistadas.

A variável de interesse deste trabalho, que é a variável indicador que capta o custo de entrada para a exportação, foi construída utilizando as seguintes variáveis existentes no banco de dados de World Bank Enterprise Survey: percentual da produção exportada no ano do questionário e em que ano a firma fez a primeira exportação. Caso a firma exporte uma parcela da sua produção (percentual exportado seja maior que zero) e o ano de início da exportação seja o ano fiscal de referência do questionário, então a variável $I\left(y_{i t}=\right.$ 1 e $y_{i t-1}=0$ ) é igual a 1 , caso contrário é igual a zero. Dado o tamanho da nossa amostra, embora apenas $0,67 \%$ da amostra total das firmas tenha iniciado sua atividade exportadora no ano do questionário, há observações suficientes para uma estimação precisa, conforme aponta a Tabela 17.

Tabela 17 - Comportamento das firmas sobre a atividade exportadora

\begin{tabular}{lcc}
\hline Característica & Quantidade & $\begin{array}{c}\text { Porcentual na } \\
\text { amostra }\end{array}$ \\
\hline \hline $\begin{array}{l}\text { Firmas que já exportaram alguma vez, mesmo que não } \\
\text { exporte no ano do questionário }\end{array}$ & 16486 & $28.52 \%$ \\
Firmas que exportaram no ano do questionário & 12836 & $22.21 \%$ \\
$\begin{array}{l}\text { Firmas que exportaram no ano do questionário pela } \\
\text { primeira vez }\end{array}$ & 388 & $0.67 \%$ \\
\hline
\end{tabular}

Fonte: Autoria própria

A variável dependente no nosso modelo, que é a receita com exportação em dólares, foi criada por nós utilizando a variável receita total em unidades monetárias do próprio país e a porcentagem da produção destinada à exportação (ambas retiradas da base de dados World Bank Enterprise Survey), e o câmbio nominal do país por dólares americanos encontrados no banco de dados do Banco Mundial. A receita em dólares com exportação das firmas que iniciaram a atividade exportadora recentemente é quase cinco vezes menor do que a receita em dólares com exportação das firmas que exportam há mais tempo.

A elasticidade da demanda externa de cada firma, $n_{i}$, foi criada através da equação (4). A receita total com a produção doméstica é criada pela multiplicação da proporção da produção voltada ao mercado doméstico pela receita total. Já o custo total de produção é criado somando-se os seguintes custos presentes na base Bank Enterprise Survey: custo total com mão-de-obra, custo total com matéria-prima e produtos intermediários, custo com 
eletricidade, custo com combustível, custo com aluguel de máquinas e equipamentos, custo com aluguel da terra e outros custos gerais. A variável $n_{i}$, estimada por nós, é compatível com a literatura existente, conforme comentamos anteriormente e conforme descreve a tabela abaixo:

\begin{tabular}{cc}
\multicolumn{2}{c}{ Tabela 18 - Distribuição de $n_{i}$} \\
\hline Percentil & Valores \\
\hline \hline 1 & 2.9 \\
2 & 5.0 \\
3 & 7.3 \\
4 & 9.7 \\
5 & 12.3 \\
6 & 15.0 \\
7 & 18.9 \\
8 & 26.4 \\
9 & 42.2 \\
\hline
\end{tabular}

Fonte: Autoria própria

As variáveis utilizadas para compor o vetor de características da firma, $z_{i}$, foram: status da firma, quantidade de trabalhadores em tempo integral, salário médio dos empregados, idade da firma, quantidade da empresa pertencente ao governo e quantidade da empresa pertencente a estrangeiros.

A variável de status legal da firma assume: valor 1 se a empresa for sociedade anônima cotada em bolsa de valores; valor 2 se for sociedade anônima, mas não cotada em bolsa; valor 3 para único proprietário; valor 4 se for sociedade; valor 5 se for sociedade limitada; e valor 6 se for outras especificações. A seguir, na Tabela 19 mostramos a porcentagem de cada tipo de firma na nossa amostra.

Tabela 19 - Percentual na amostra

\begin{tabular}{ccccc}
\hline Status legal & Amostra total & $\begin{array}{c}\text { Apenas não } \\
\text { exportadoras }\end{array}$ & $\begin{array}{c}\text { Tradicionalmente } \\
\text { exportadoras }\end{array}$ & $\begin{array}{c}\text { Exportadoras } \\
\text { recentes }\end{array}$ \\
\hline \hline 1 & 5,3 & 4,5 & 8,0 & 3,6 \\
2 & 47,0 & 42,6 & 63,0 & 60,7 \\
3 & 33,1 & 38,1 & 15,6 & 20,6 \\
4 & 7,0 & 7,5 & 5,1 & 5,9 \\
5 & 5,6 & 5,4 & 5,7 & 6,9 \\
6 & 2,0 & 1,9 & 2,5 & 2,3 \\
\hline
\end{tabular}

Fonte: Autoria própria 
Vale notar que a frequência de empresas sociedade anônima (tipo 2) dentre as tradicionalmente exportadoras e as exportadoras recentes se sobressai fortemente em relação às não exportadoras.

As outras variáveis estão descritas na Tabela 20. Como se pode ver, na média, a amostra é composta de firmas com 117 funcionários, porém há empresas que chegam a empregar até 64,5 mil trabalhadores. O salário médio anual de um trabalhador é de US\$ 1.340,00, as firmas entrevistadas têm ao redor de 18 anos, porém também é possível encontrar empresas centenárias e a porcentagem das firmas detidas pelo governo e por estrangeiros é, em média, de $0,75 \%$ e $8,9 \%$ respectivamente.

Tabela 20 - Estatística descritiva das demais variáveis

\begin{tabular}{lcccc}
\hline Variável & Média & Desvio-padrão & Mínimo & Máximo \\
\hline \hline Número de empregados em período integral & 116,8 & 581 & 0 & 64500 \\
Salário médio anual & 1340 & 14682 & 0 & 1249212 \\
Idade da firma (em anos) & 18 & 16 & 0 & 340 \\
Porcentagem da firma pertencente ao governo & $0,75 \%$ & $7 \%$ & $0 \%$ & $100 \%$ \\
Porcentagem da firma pertencente a estrangeiros & $8,9 \%$ & $26,7 \%$ & $0 \%$ & $100 \%$ \\
\hline
\end{tabular}

Fonte: Autoria própria

Estas variáveis se comportam de maneira distinta dependendo do posicionamento da firma frente ao comércio internacional. Por exemplo, conforme descreve a Tabela 21, as firmas incumbentes no comércio internacional são maiores, mais velhas, têm uma maior participação do governo e de estrangeiros na estrutura societária, e neste caso, pagam menores salários.

Tabela 21 - Média das variáveis dada a classificação da firma

\begin{tabular}{lccc}
\hline Variável & $\begin{array}{c}\text { Não } \\
\text { exportadoras }\end{array}$ & $\begin{array}{c}\text { Tradicionalmente } \\
\text { exportadoras }\end{array}$ & $\begin{array}{c}\text { Exportadoras } \\
\text { recentes }\end{array}$ \\
\hline \hline Número de empregados em período integral & 70,8 & 283,2 & 109,9 \\
Salário médio anual & 1468 & 888 & 1006 \\
Idade da firma (em anos) & 16,3 & 22,9 & 11,8 \\
Porcentagem da firma pertencente ao governo & $0,67 \%$ & $0,97 \%$ & $0,27 \%$ \\
Porcentagem da firma pertencente a estrangeiros & $6,42 \%$ & $17,83 \%$ & $12,7 \%$ \\
\hline
\end{tabular}

Fonte: Autoria própria

Já o vetor $x_{t}$ é composto pelo câmbio PPP, para cada país existente na amostra, referente ao ano anterior e corrente à entrevista, e foi retirado também do Banco Mundial.

As variáveis institucionais presentes em World Bank Enterprise Survey, e utilizadas por nós, consideram a resposta do entrevistado sobre o grau de dificuldade que a variável em questão representa para as operações da firma, assumindo valor 0 se não é um obstáculo; 
valor 1 se é um pequeno obstáculo; valor 2 se é um obstáculo moderado; valor 3 se é um grande obstáculo e valor 4 se é um obstáculo muitíssimo severo. A Tabela 22 mostra o percentual das respostas das firmas na nossa amostra completa sobre este tema.

Tabela 22 - Percentual das respostas dadas pelas firmas aos problemas institucionais

\begin{tabular}{lccccccc}
\hline $\begin{array}{l}\text { Nível de dificuldade à } \\
\text { atividade da empresa }\end{array}$ & $\begin{array}{c}\text { regulação } \\
\text { aduaneira }\end{array}$ & $\begin{array}{c}\text { setor } \\
\text { informal }\end{array}$ & $\begin{array}{c}\text { licenças/per instabilidade } \\
\text { missões }\end{array}$ & política & corrupção & justiça & $\begin{array}{c}\text { leis } \\
\text { trabalhistas }\end{array}$ \\
\hline \hline & & & & & & & \\
não é obstáculo & 50,84 & 32,5 & 43,62 & 35,27 & 31,62 & 49,28 & 46,47 \\
pequeno obstáculo & 18,62 & 17,93 & 21,75 & 14,64 & 15,88 & 18,81 & 21,95 \\
obstáculo moderado & 16.0 & 20,37 & 18,85 & 16,62 & 15,81 & 15,46 & 19,02 \\
grande obstáculo & 9,33 & 16,45 & 10,82 & 18,31 & 18,87 & 10,29 & 8,68 \\
obstáculo muitíssimo severo & 5,21 & 12,76 & 4,96 & 15,17 & 17,83 & 6,16 & 3,88 \\
\hline
\end{tabular}

Fonte: Autoria própria

Como podemos verificar, há uma grande dispersão entre as respostas das empresas em relação ao nível de dificuldade imposto à operação das firmas pelas variáveis institucionais. Além disso, o percentual das firmas que responderam a estas perguntas é extremamente elevado, em média de $96 \%$.

Para facilitar nossa análise futura transformamos as variáveis institucionais em variáveis dicotômicas. Cada variável institucional terá valor igual a 1 nos casos em que a firma classificar a instituição como um obstáculo moderado, grande ou severo, caso contrário a variável assumirá valor 0 .

\subsection{RESULTADOS}

\subsubsection{Estimação da probabilidade de uma firma ser exportadora}

Conforme explicamos na seção de metodologia, antes de calcularmos em valor monetário o custo fixo de entrada para a exportação replicamos, com adaptações, o exercício de Bernard e Jensen (2004). Isto significa que estimamos modelos de escolha discreta (probit) a fim de identificar os determinantes da escolha de a firma se tornar uma exportadora, ou seja, regredimos a variável dicotômica ser ou não exportadora em função de características da firma, de variáveis macroeconômicas e da experiência anterior da firma com exportação.

Neste contexto, testamos se há indícios de existência de custos fixos de entrada para a exportação enfrentados pelas firmas da nossa amostra, bem como se o país no qual a firma está instalada exerce alguma influência na probabilidade de a firma ser uma exportadora. 
Conforme apresentado pela Tabela 23, a regressão, utilizando a nossa amostra de mais de 57 mil firmas espalhadas por 123 países, gerou resultados em linha tanto com a estatística descritiva da seção anterior como com a literatura. Mais precisamente, conforme mostra a coluna 1 da Tabela 23, encontramos que a probabilidade de a firma ser exportadora aumenta quanto mais a firma se aproximar de uma empresa com ações cotadas em bolsa de valores, quanto maior for o tamanho da empresa (em termos de número de funcionários), quanto mais depreciado estiver o câmbio PPP no ano anterior, quanto mais antiga for a empresa e quanto maior for a porcentagem da firma pertencente a estrangeiros ou ao governo. E, finalmente, como destaque de nossa análise, a experiência prévia com exportação, capturada aqui pela variável dummy que assume valor 1 se a firma exportou no passado e zero caso contrário, aumenta consideravelmente a probabilidade da firma exportar no presente. Este resultado, conforme sugerido por Bernard e Jensen (2004), é um indício de que existem custos fixos de entrada para a exportação.

Tabela 23 - Modelo Probit sobre a decisão de exportar

\begin{tabular}{lcc}
\hline & 1 & 2 \\
\hline \hline Dummy se exportou no passado & $4,23 * * *$ & $4,75 * * *$ \\
Status legal da firma & $-0,036^{* * *}$ & $-0,068^{* * *}$ \\
Número total de trabalhadores (x 1000) & $0,11^{* * *}$ & $0,116^{* * *}$ \\
Ano de início da atividade da firma & $0,009 * * *$ & $0,008^{* * *}$ \\
\% da firma pertencente ao governo & $0,003^{* * *}$ & $0,004^{* * *}$ \\
\% da firma pertencente a estrangeiros & $0,007^{* * *}$ & $0,006 * * *$ \\
Câmbio PPP no ano anterior & $0,861^{* * *}$ & 0,612 \\
Constante & $-2,23 * * *$ & $-2,40 * * *$ \\
\hline no de observações & 54995 & 54995 \\
R2 ajustado & 0,71 & 0,75 \\
\hline
\end{tabular}

${ }^{*}$ signficante a $10 \%,{ }^{* *}$ significante a $5 \% \mathrm{e}^{* * *}$ significante a $1 \%$

(2) contém dummies para país

Fonte: Autoria própria

Na coluna 2 da Tabela 23 acrescentamos dummies de país à regressão, pois queríamos testar se o país na qual a firma está localizada influencia na decisão de a firma ser exportadora. Os resultados confirmaram nossa suspeita; 63 das 123 dummies de países são estatisticamente significantes a pelo menos $10 \%$ de nível de significância, o que demonstra que há elementos do país que tornam o ambiente mais ou menos propício à exportação. Nossa hipótese é de que o custo de entrada para a exportação pode diferir entre os países, o que explicaria ao menos em parte, porque firmas com características semelhantes localizadas em países diferentes tomam decisões opostas em relação à exportação. Além disso, vale notar que 
os coeficientes associados às demais variáveis explicativas, no geral, pouco se alteram com a introdução das dummies de país, refletindo a robustez dos nossos resultados.

Sendo assim, diante das evidências encontradas, nas próximas seções estimamos, através da adaptação do modelo de Das, Roberts e Tybout (2007), o valor do custo médio de entrada para exportação. Além disso, utilizamos este mesmo modelo para estimar se o custo de entrada para exportação difere por país.

\subsubsection{Estimação do custo fixo médio de entrada para a exportação nos países em desenvolvimento}

Nesta subseção, fazendo uso do modelo adaptado de Das, Roberts e Tybout (2007) descrito na seção de Metodologia, estimamos o custo fixo médio de entrada para a exportação em dólares enfrentado pelas firmas localizadas em países em desenvolvimento. Os resultados estão reportados na Tabela 24 e apontam que nossa variável de interesse, que é a variável indicador que marca o início da atividade exportadora, apresenta um coeficiente estatisticamente significante e negativo, em linha com o esperado, pois ao adentrar o comércio internacional a receita e, consequentemente, o lucro com a exportação cai. Isto significa que nos países em desenvolvimento, em média, as firmas arcam com um custo extra quando decidem começar a exportar confirmando os achados da literatura para certos países ou regiões.

Vale notar que esta relação negativa e estatisticamente significante se mantém desde a estimação de uma regressão simples via OLS, reportada na coluna (1), passando pela estimação com controles via OLS, reportada na coluna (2), até, finalmente, a estimação via Tobit tipo II, reportada na coluna (3). E, como esperado, após introduzir controles e corrigir o viés de seleção a magnitude do coeficiente diminui.

Também é importante ressaltar que, conforme exposto na Tabela 24 , o teste LR confirma a existência de viés de seleção na equação principal ao mesmo tempo que a significância estatística de razão de Mills sugere que a equação de seleção corrige este viés. Portanto, tomamos como resultados finais os gerados pelo método de Tobit tipo II, descritos nas colunas (3) e (4) da Tabela 24.

Sendo assim, após álgebra simples, encontramos que a média do custo fixo de entrada para a exportação é de US\$3,2 milhões ${ }^{19}$. Portanto, uma firma só irá iniciar suas atividades

\footnotetext{
${ }^{19}$ De acordo com Halvorsen e Palmquist (1980), como a forma funcional é log-lin e a variável explicativa é dicotômica precisamos fazer uma correção para sua correta interpretação, isto é, precisamos aplicar o antilog do coeficiente da dummy e subtrair 1.
} 
exportadoras se o lucro esperado com a exportação compensar este gasto que, apesar de ocorrer apenas uma única vez, é bastante pronunciado. Este resultado sugere que o custo fixo de entrada deve ser um inibidor da atividade exportadora das firmas.

Tabela 24 - Resultados do modelo básico

\begin{tabular}{|c|c|c|c|c|}
\hline & $\begin{array}{l}\text { Logarítmo da } \\
\text { receita com } \\
\text { exportação }\end{array}$ & $\begin{array}{l}\text { Logarítmo da } \\
\text { receita com } \\
\text { exportação }\end{array}$ & $\begin{array}{c}3 \\
\text { Eq. Principal } \\
\text { Logarítmo da } \\
\text { receita com } \\
\text { exportação }\end{array}$ & $\begin{array}{c}4 \\
\text { Eq. Seleção } \\
\text { Ser exportadora }\end{array}$ \\
\hline Variável & variável contínua & variável contínua & variável contínua & variável binária \\
\hline Início da atividade exportadora & $-1,73 * * *$ & $-1,30 * * *$ & $-1,01 * * *$ & \\
\hline Elasticidade-preço da demanda externa & & $-0,45 * * *$ & $0,12 * * *$ & $-0,20 * * *$ \\
\hline Status legal & & $-0,12 * * *$ & $0,18^{* * *}$ & $-0,08 * * *$ \\
\hline Número total de trabalhadores $\left(x 10^{3}\right)$ & & $0,57 * * *$ & $0,51 * * *$ & $0,41 * * *$ \\
\hline Salário médio anual $\left(\times 10^{3}\right)$ & & $0,03 * * *$ & $0,05 * * *$ & $0,01 * * *$ \\
\hline Idade da firma & & $0,02 * * *$ & $-0,01 * * *$ & $0,01 * * *$ \\
\hline Porcentagem da firma pertencente ao governo & & $0,01 * * *$ & $0,01 * * *$ & -0.01 \\
\hline Porcentagem da firma pertencente a estrangeiros & & $0,01 * * *$ & $-0,01 * * *$ & $0,01 * * *$ \\
\hline Câmbio PPP do ano corrente & & $2,30 * * *$ & 0,03 & 0,19 \\
\hline Câmbio PPP do ano anterior & & $-1,12 * *$ & $1,39 * *$ & $-0,22$ \\
\hline _cons & $17,93 * * *$ & $17,79 * * *$ & $20,71 * * *$ & $-0,44 * * *$ \\
\hline Razão de Mills & & & $-3,40 * * *$ & \\
\hline Língua Francesa & & & & $-0,30 * * *$ \\
\hline Língua Inglesa & & & & $-0,14 * * *$ \\
\hline Saída para o mar & & & & $0,15^{* * *}$ \\
\hline no de observações & 12456 & 11913 & 530 & 091 \\
\hline $\mathrm{R}^{2}$ & 0,012 & 0,192 & & \\
\hline Observações censuradas & - & - & 411 & 178 \\
\hline Observações não censuradas & - & - & & 913 \\
\hline \multicolumn{5}{|c|}{ \#Teste LR para existência de viés de seleção $($ rho $=0): \quad$ chi2 $(1)=1831$ Prob $>$ chi2 $=0.0000$} \\
\hline
\end{tabular}

Com relação às demais variáveis, na equação de seleção (coluna 4), a qual estima a probabilidade de a firma ser exportadora ou não, encontramos resultados coerentes com a literatura e com nossas estimações anteriores. Isto é, quanto mais o status da firma se aproximar de uma empresa cotada em bolsa de valores, quanto mais empregados a firma tiver, quanto maiores forem os salários pagos pela firma, quanto mais antiga for a empresa e quanto maior a porcentagem da firma detida por estrangeiros, maior a probabilidade da firma ser exportadora. Além disso, também em linha com a teoria econômica, quanto maior a elasticidade da demanda externa da firma, menor a probabilidade de a mesma ser uma exportadora. Já o câmbio e a porcentagem da firma detida pelo governo não afetam de maneira estatisticamente significante a variável dependente. 
As variáveis instrumentais, língua inglesa, língua francesa e saída para o mar foram estatisticamente significantes e, de acordo com a significância da razão de Mills, se mostraram adequadas para corrigir o viés de seleção. Com relação à direção do efeito, a existência de litoral aumenta a probabilidade de uma firma ser exportadora, em linha com nossa hipótese, já a língua oficial do país ser o inglês ou o francês diminui a probabilidade da firma ser exportadora, contrariando nossa expectativa inicial. Uma possível explicação para este fato seria que, como estamos tratando de países em desenvolvimento, grande parte das ex-colônias francesas e inglesas está localizada na África, região com grande concentração de países muito pobres e, provavelmente, com poucas empresas internacionalmente competitivas.

Com relação à nossa equação de interesse (coluna 3), que visava decompor a receita com exportação, e consequentemente, o lucro com exportação em função do custo de entrada para exportação e das variáveis presentes nos vetores $z_{i t}$ e $x_{t}$, encontramos resultados também bastante interessantes.

Temos que o logaritmo da elasticidade da demanda externa é estatisticamente significante e positivo, conforme previsto pelo modelo. Além disso, quanto maior for a empresa em termos de quantidade de funcionários, quanto maior for o salário médio pago pela firma e quanto maior for a quantidade da empresa detida pelo governo, maior será o logaritmo da receita da firma com exportação. Por outro lado, quanto mais próxima do status de uma empresa cotada em bolsa de valores, quanto mais antiga for a firma e quanto maior for a participação de estrangeiros na estrutura societária da mesma, menor será o logaritmo da receita com exportação.

Já a relação ao vetor $x_{t}$, encontramos que, quanto mais depreciado for o câmbio ${ }^{20}$ do ano anterior ao da exportação, maior será a receita da firma com a atividade exportadora; resultado este também em linha com a teoria econômica.

\subsubsection{Estimação do custo fixo de entrada para a exportação para cada país}

Após encontrar que existe um expressivo custo fixo de entrada para a exportação para a média dos países em desenvolvimento, na presente subseção replicamos a estimação feita na subseção anterior interagindo a variável de entrada para a exportação da firma com o país de residência da mesma (dummies de país) a fim de encontrar custos fixos de entrada para a exportação para cada país.

\footnotetext{
${ }^{20}$ Câmbio PPP
} 
Os resultados desta re-estimação confirmaram nossa hipótese de que o custo fixo de entrada para exportação difere conforme o país em que a firma está localizada. Embora não haja dados suficientes para a estimação para todos os países que compõem a amostra por conta desta variável ser muito específica, conseguimos ranquear o custo fixo de entrada para a exportação para 72 países conforme se observa na Figura 2. Quanto mais positivo (ou negativo) o valor estimado, menor (ou maior) é o custo de entrada para a exportação do país em comparação à referência.

Para ampliar o entendimento, estimamos os custos fixos de entrada para exportação para cada país em referência a três outros países. São estes: China (em cinza) dada sua relevância no cenário econômico internacional, Colômbia (em azul) por ser o país com maior número de observações para a variável construída interagindo a dummy de entrada para a exportação e a dummy de país e, finalmente, México (em vermelho) por ser um país cujo custo de entrada para a exportação é próximo à média da amostra e por ser um país semelhante ao Brasil. 
Figura 2 - Custo fixo de entrada para a exportação em cada país em relação ao custo de outro país

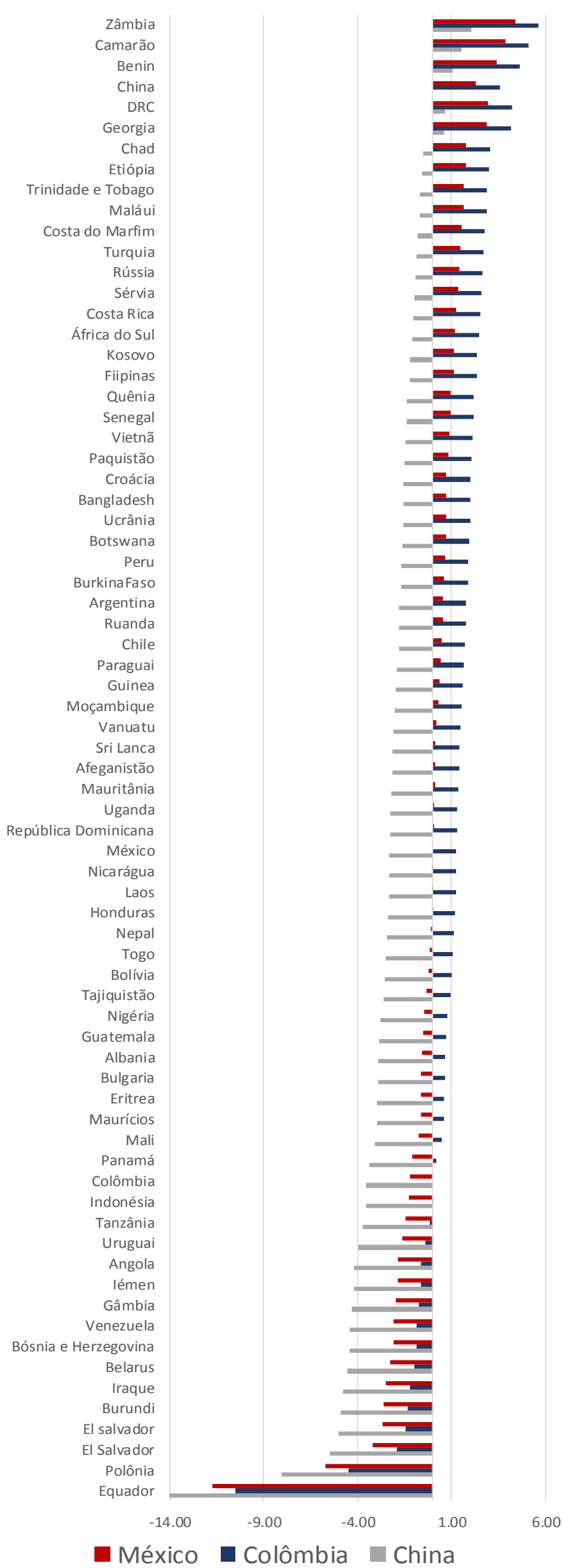

Fonte: Autoria própria 
Conforme podemos observar pela Figura 2, pouquíssimos países apresentam um valor positivo em relação ao custo fixo de entrada para exportação da China ${ }^{21}$. Isto significa que poucos países têm um custo fixo de entrada para a exportação menor do que o encontrado na China. Analogamente, a maioria dos países apresentam um valor negativo em relação ao custo fixo de entrada para a exportação na China, consequentemente as firmas localizadas nestes países pagam um valor superior ao pago por empresas localizadas na China para iniciar a atividade exportadora.

O oposto ocorre quando comparamos com o custo fixo de entrada para exportação da Colômbia. A maioria dos países apresenta um valor positivo em relação à Colômbia, o que significa que na maioria dos países o custo fixo de entrada para exportação pago pelas firmas é menor do que aquele pago pelas empresas residentes na Colômbia. Já na comparação com o México, a relação é mais equilibrada, há 40 países cujo custo fixo de entrada para exportação é menor do que o do México e 31 países com custo fixo de entrada para exportação maior do que o do México.

\subsubsection{A relação entre os custos fixos de entrada para a exportação de cada país e a probabilidade da firma ser exportadora em cada país}

Após verificar que países diferem quanto ao custo fixo de entrada para a exportação, testamos a nossa hipótese de que essa diferença pode explicar, ao menos em parte, porque firmas com características semelhantes têm probabilidades diferentes de exportar em função dos países no qual elas estão instaladas. Para isso regredimos o coeficiente associado a dummy de país do modelo Probit exposto na coluna 2 da Tabela 23 em função do coeficiente associado ao custo fixo de entrada para exportação de cada país estimado na seção anterior ${ }^{22}$.

A variável que compila os coeficientes associados a dummy de país do modelo Probit foi nomeada por nós de $P E$ e possui média igual a 0,26 e com amplitude de $-0,5$ até $+1,35$. Isto significa que, controlando pelas características privadas das firmas, uma empresa localizada em um país com PE negativo tem uma menor probabilidade de ser exportadora enquanto que o contrário ocorre se esta empresa está localizada em um país com PE positivo e elevado.

\footnotetext{
${ }^{21}$ Vale notar que 41 das 72 variáveis construídas pela interação entre a dummy de entrada para exportação e a dummy de país são estatisticamente significantes a pelo menos $10 \%$ de nível de significância.

${ }^{22}$ Vale notar que utilizaremos apenas dados de países para os quais foi possível calcular o custo fixo de entrada para a exportação. Portanto, a abrangência da nossa amostra passa de 123 para 72 países.
} 
Podemos citar Angola, Tanzânia e Burundi como exemplos de países com PE negativo e, por outro lado, temos Turquia e Argentina com PE positivo.

Já o coeficiente associado ao custo fixo de entrada para a exportação para cada país estimado na seção anterior, o qual nomeamos de CFE, tem média negativa e também grande variabilidade. No caso do Equador, por exemplo, o CFE estimado é de -13,1, o que mostra que o custo de entrada para a exportação neste país é expressivo. Mas, para alguns países como a China, por exemplo, este valor é positivo (no caso igual a 1,08) o que sugere que o custo de entrada para exportação neste país é muito menor do que a média dos países da amostra.

Conforme podemos ver na Figura 3 há uma relação direta entre a probabilidade de firmas instaladas em determinado país serem exportadoras e o custo fixo de entrada para a exportação neste mesmo país. Portanto, como esperado, em países como a China a probabilidade de as firmas serem exportadoras é alta, enquanto que empresas situadas em países cujo custo de entrada para a exportação é elevado têm uma probabilidade menor de exportar.

Figura 3 - Probabilidade de exportação no país em função do CFE

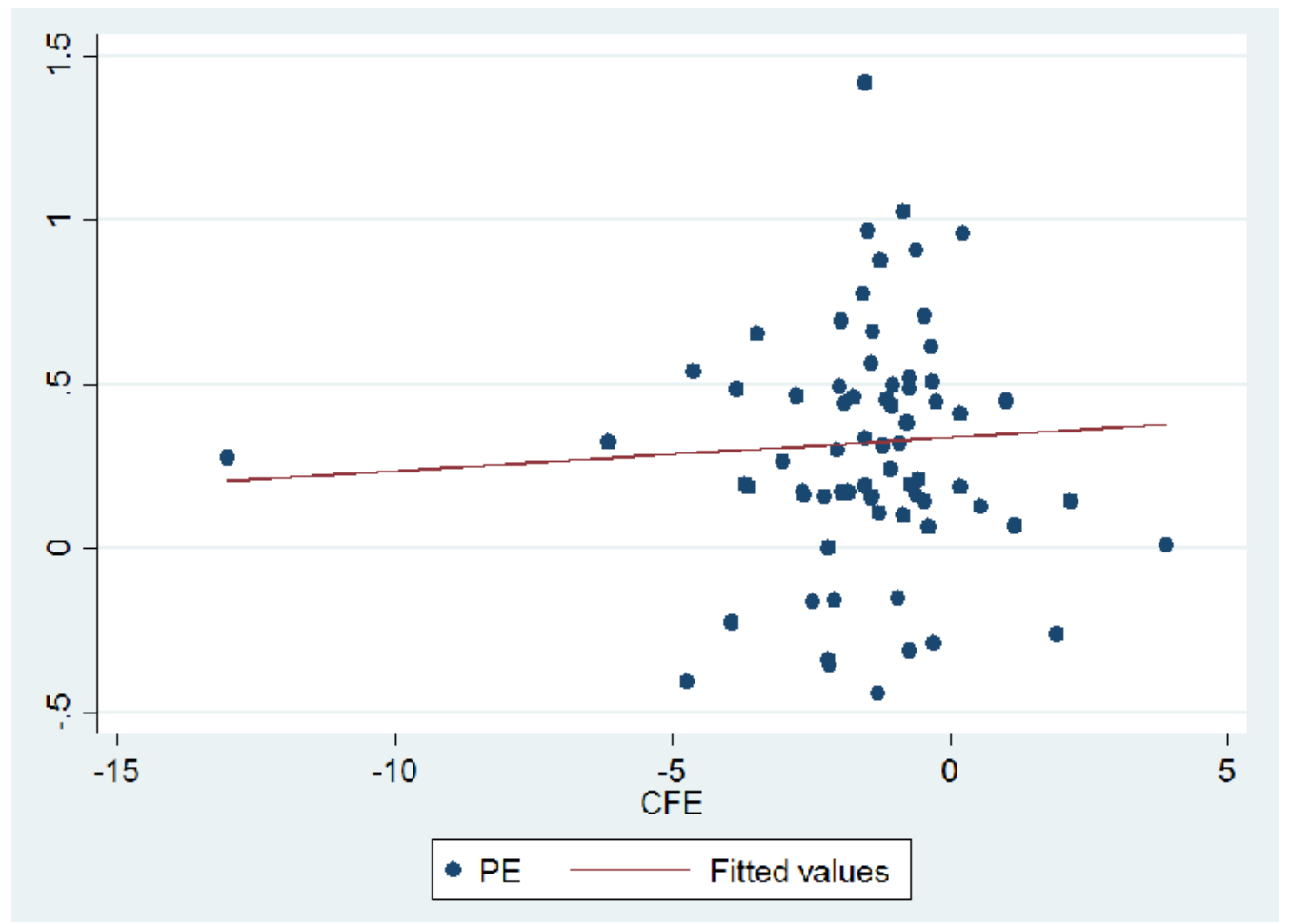

Fonte: Autoria própria 


\subsubsection{A relação entre os custos fixos de entrada para a exportação e a qualidade das instituições}

Nas seções anteriores, constatamos que o custo fixo de entrada para a exportação difere entre os países e que isto ajuda a explicar porque firmas semelhantes localizadas em países diferentes têm probabilidades distintas de exportar. Diante destes resultados, fizemos mais um exercício a fim de testar se os diferentes custos de entrada para a exportação têm alguma relação com a qualidade das instituições dos países.

Neste contexto, correlacionamos a porcentagem das firmas em cada país que atribuem valor 1 à instituição analisada e os custos fixos de entrada para a exportação (CFE) de cada país $^{23}$. Vale lembrar que as variáveis institucionais foram definidas como sendo igual a um quando a instituição representa um problema para a atividade da firma e zero caso contrário e que, quanto maior o custo fixo de entrada para a exportação, mais negativa é a variável (CFE). Portanto, esperávamos que esta relação fosse negativa para indicar que quanto maior o custo fixo de entrada para a exportação (CFE) do país, e, portanto, quanto mais negativa for a CFE, maior a porcentagem das firmas neste país que consideram as instituições do mesmo como um obstáculo à atividade da firma. De modo geral é isto que encontramos, conforme mostrado no conjunto de figuras a seguir.

Figura 4 - CFE e a qualidade das leis aduaneiras

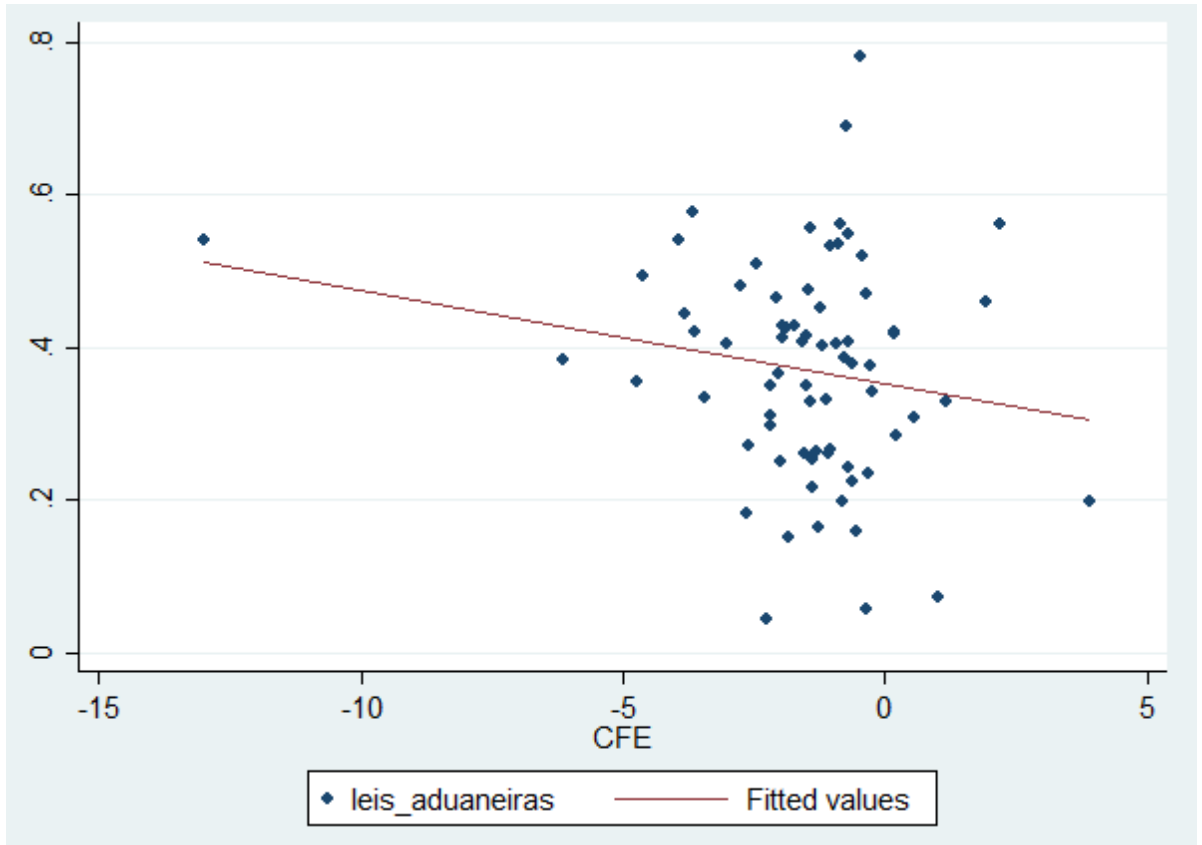

Fonte: Autoria própria

\footnotetext{
${ }^{23}$ Assim como na subseção anterior, utilizaremos apenas dados de países para os quais foi possível calcular o
} custo fixo de entrada para a exportação (CFE). 
Figura 5 - CFE e a concorrência com setor informal

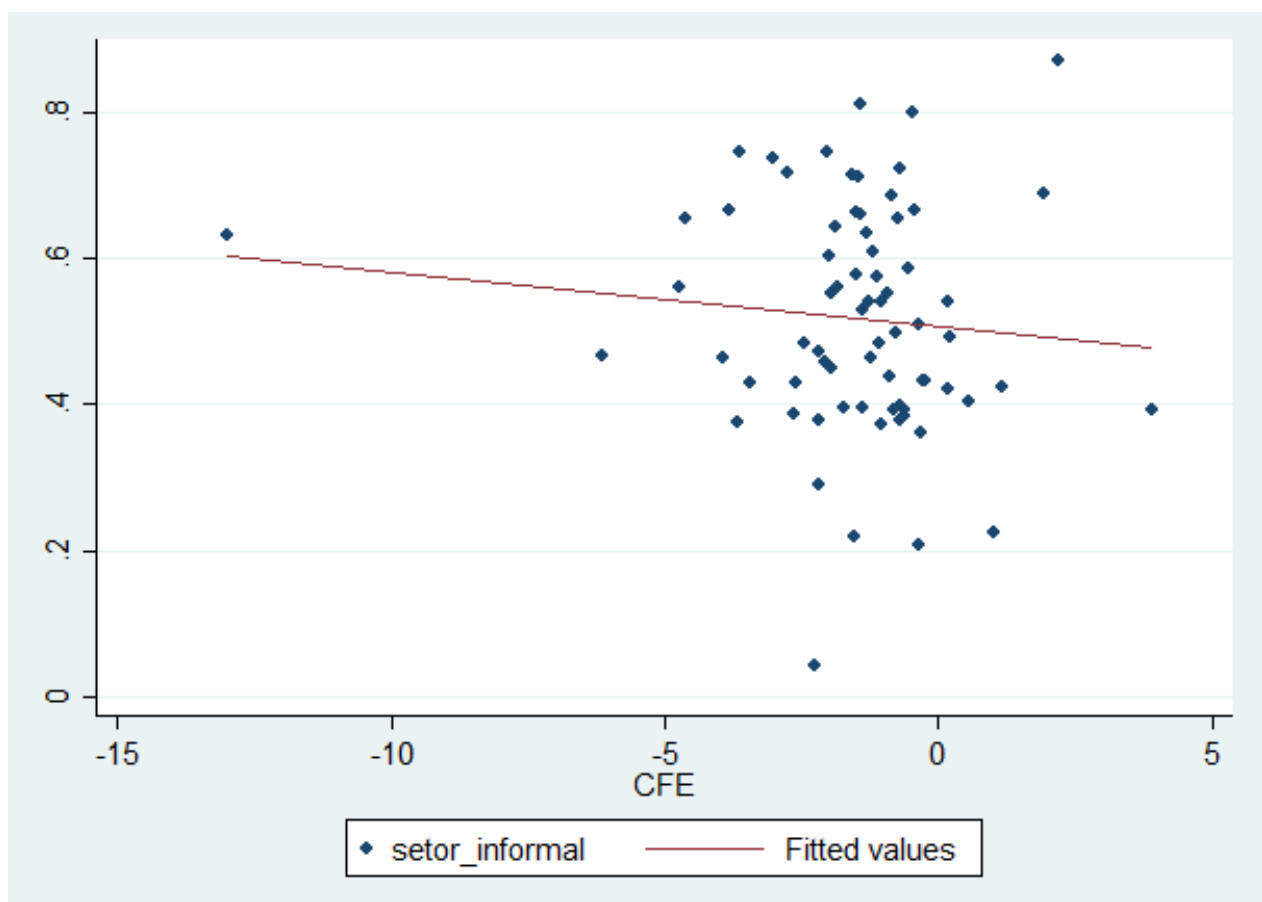

Fonte: Autoria própria

Figura 6 - CFE e a dificuldade de se conseguir um alvará

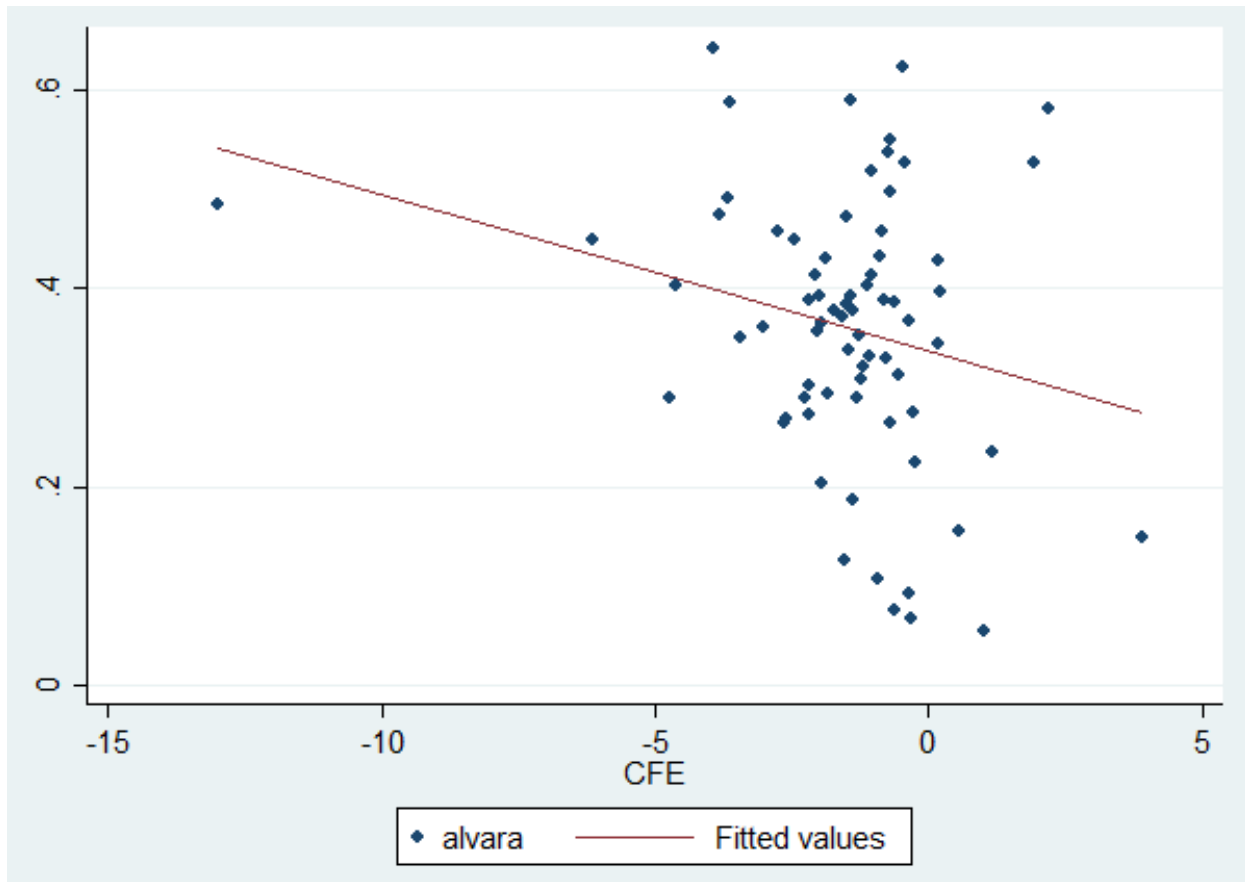

Fonte: Autoria própria 
Figura 7 - CFE e instabilidade política

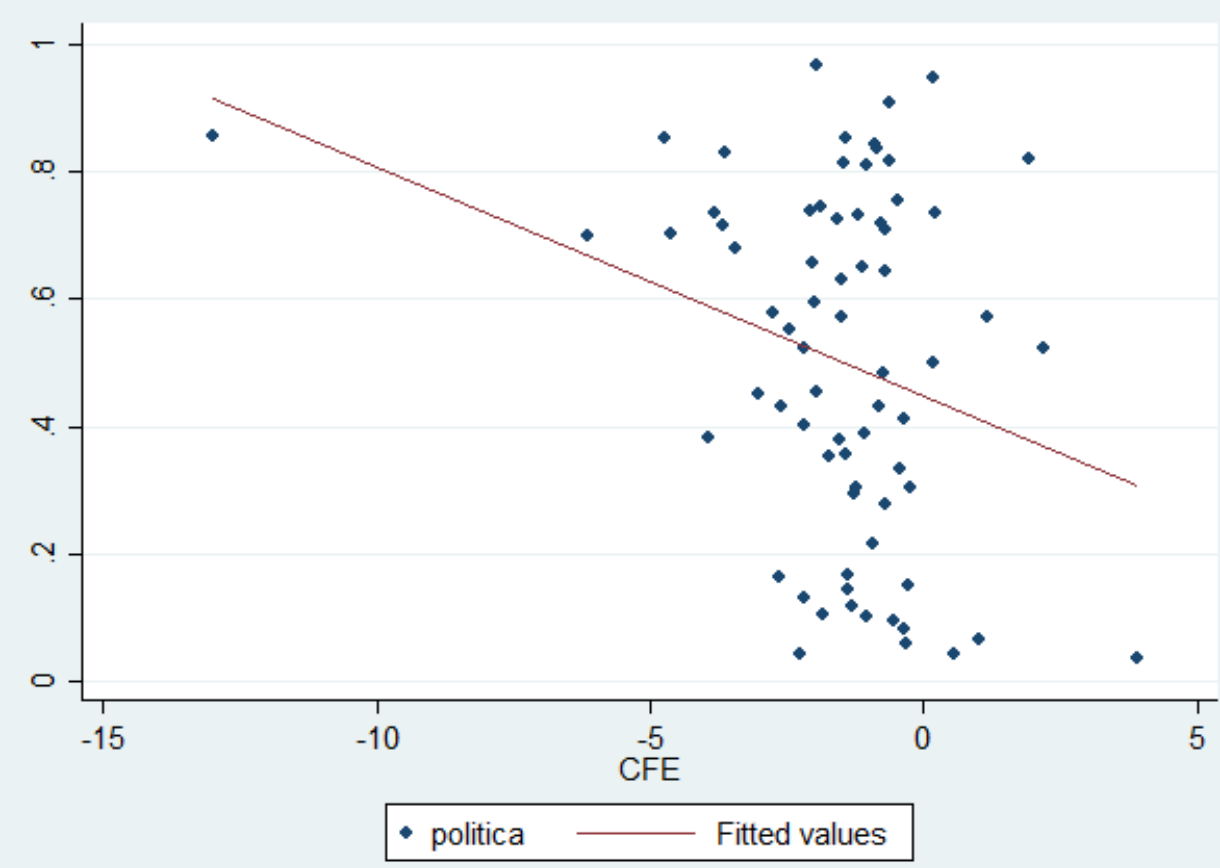

Fonte: Autoria própria

Figura 8 - CFE e grau de corrupção

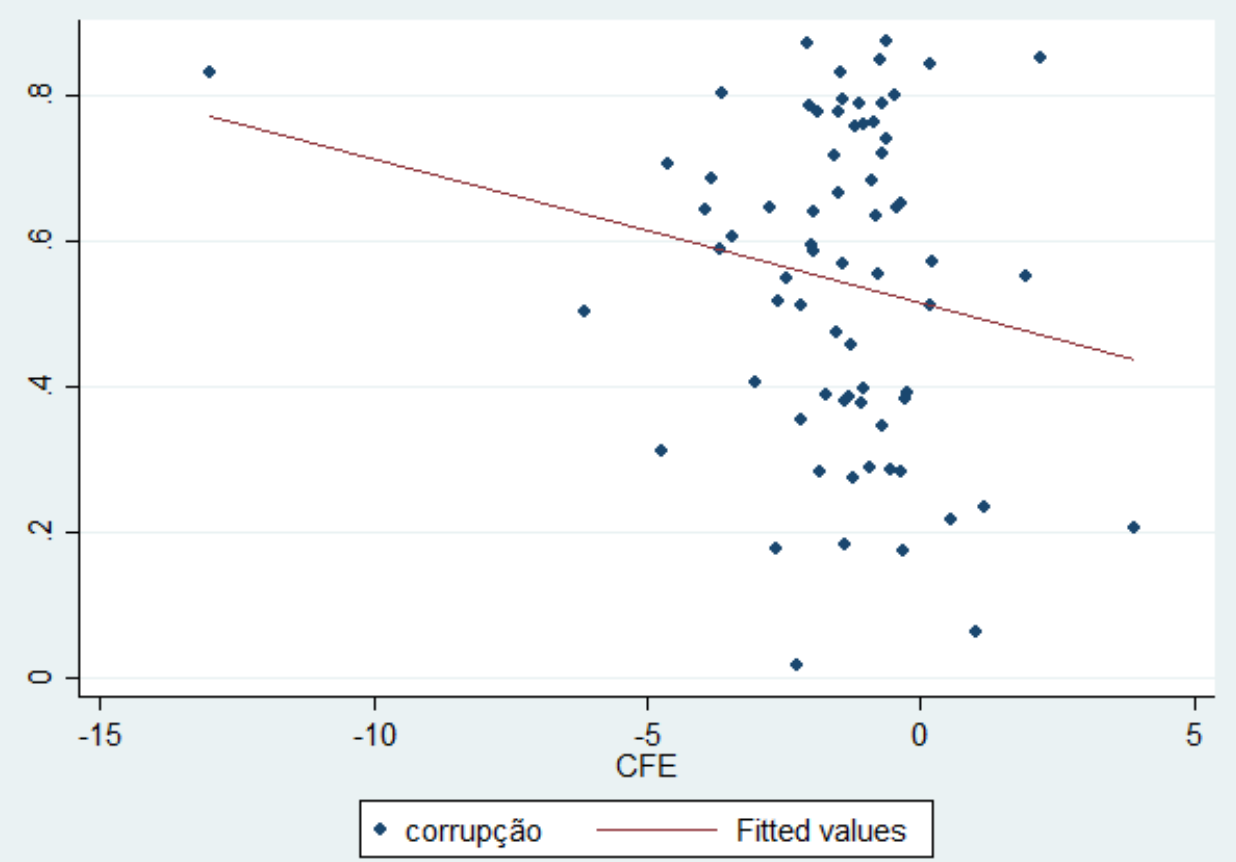

Fonte: Autoria própria 
Figura 9 - CFE e a qualidade da justiça

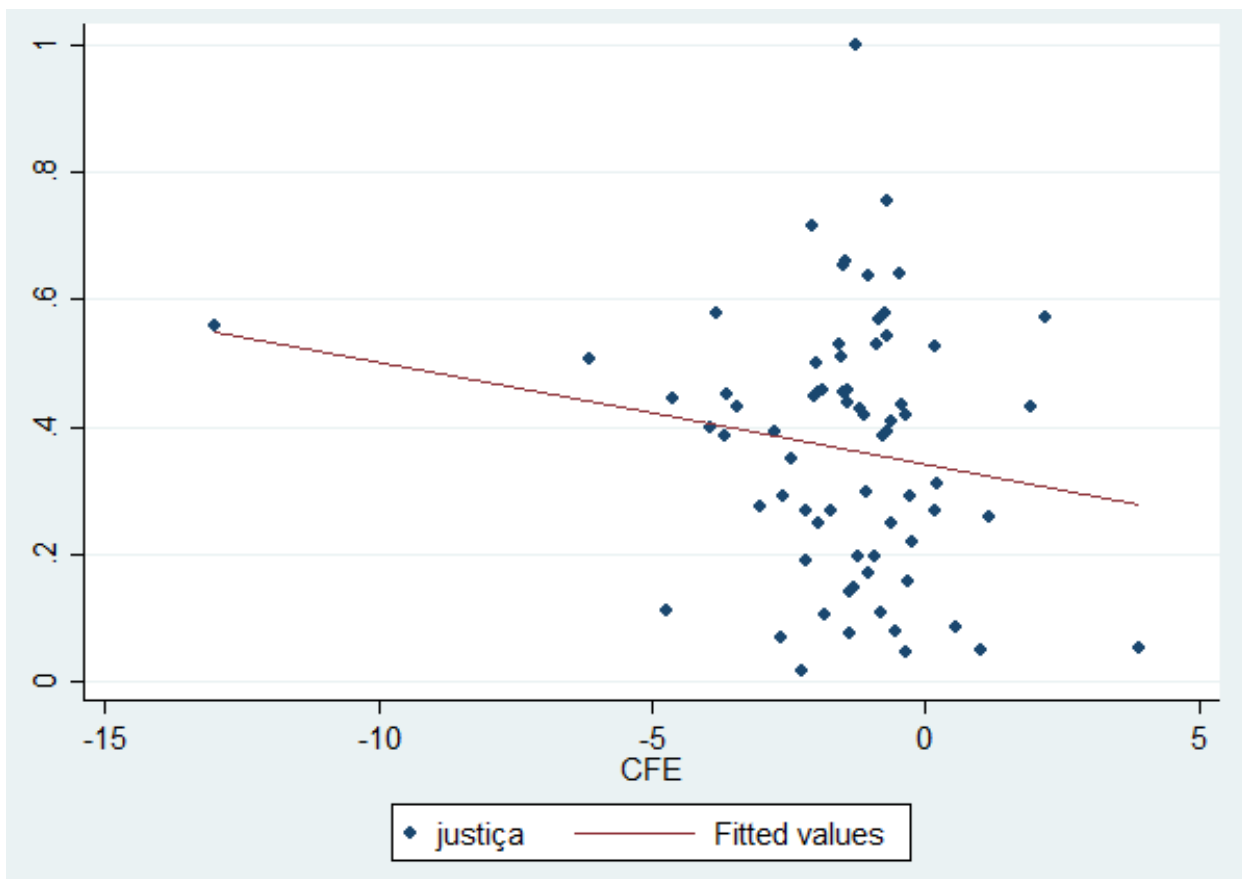

Fonte: Autoria própria

Figura 10 - CFE e a qualidade das leis trabalhistas

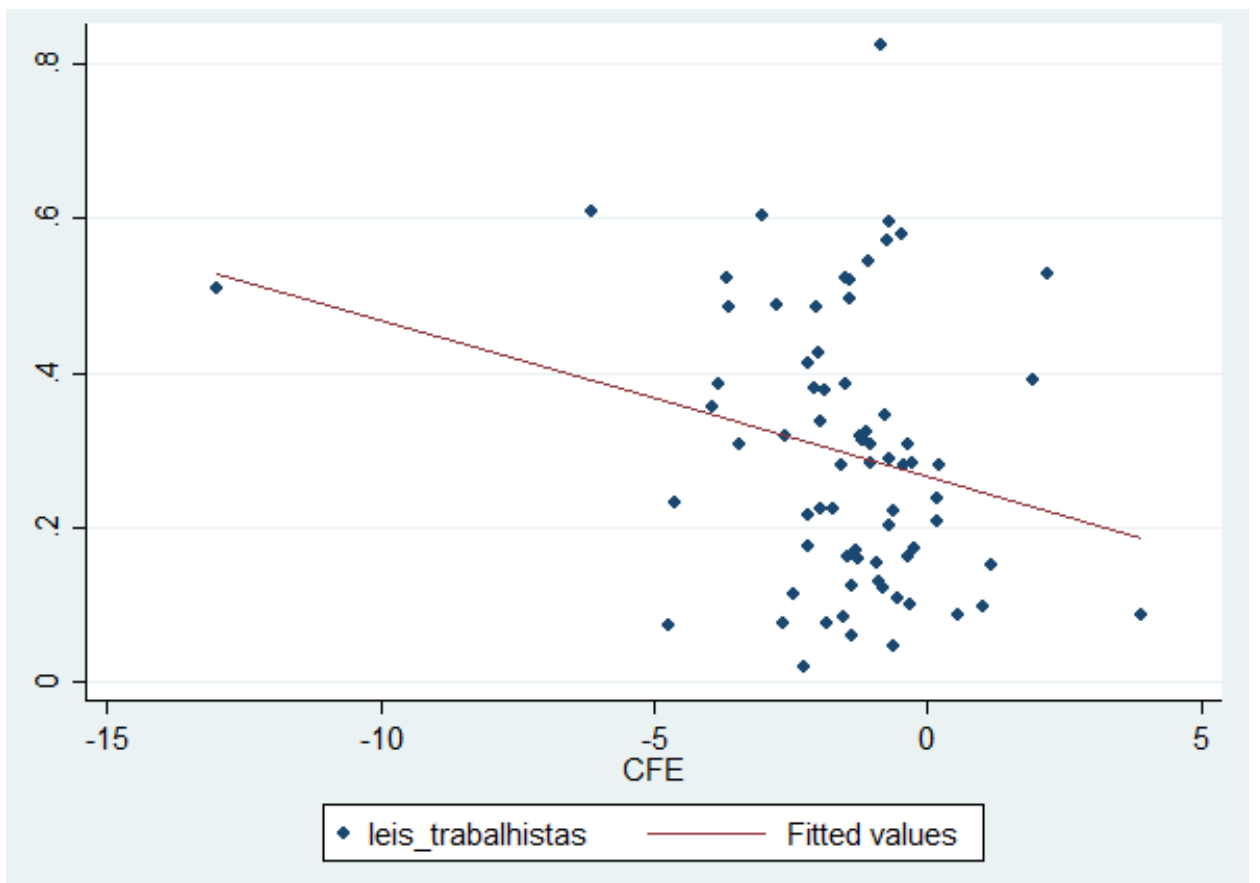

Fonte: Autoria própria

Estes resultados vão ao encontro da nossa hipótese de que, quanto mais danoso à economia forem as leis aduaneiras, a concorrência com o setor informal, a burocracia para 
obter alvarás, a instabilidade política, a ineficiência da justiça e as leis trabalhistas, maior será o custo fixo de entrada para a exportação do país.

\subsection{CONCLUSÃO}

Dentro da literatura de comércio internacional há uma linha que tenta explicar porque certas firmas exportam e outras não. Uma explanação bastante aceita é a descrita por Melitz (2003) que atribui ao custo fixo de entrada para a exportação um papel central. De acordo com este autor, apenas as firmas mais produtivas seriam capazes de arcar com este custo e, portanto, de exportar. Neste contexto, diversos trabalhos empíricos utilizando os mais variados métodos encontraram fortes evidências de que há custos de entrada enfrentados pelas firmas quando estas decidem exportar. Contudo, estes estudos utilizam dados de apenas um único país ou poucos países e setores, o que levanta dúvidas se o custo de entrada encontrado nestes trabalhos não seria uma peculiaridade do país ou do setor analisado. Nosso trabalho contribui com a literatura justamente por demonstrar que este custo fixo associado à decisão da firma começar a exportar existe para a média dos mais diversos setores de atividade espalhados em mais de 120 países em desenvolvimento e que seu valor médio é de US\$3,2 milhões.

Além disso, encontramos que o custo fixo de entrada para exportação difere da média para pelo menos 72 países que compõem a nossa amostra. Ou seja, há países em que o custo fixo de entrada para a exportação é bem pequeno enquanto que para outros países este custo é bastante elevado. Adotando a teoria de Melitz (2003), isto significa que existe a possibilidade de que firmas muito semelhantes com produtividade parecidas adotem decisões distintas em relação a exportar porque estão localizadas em países diferentes, os quais possuem diferentes valores para o custo fixo de entrada para a exportação. É justamente sob este contexto que testamos e encontramos resultados que sugerem que a heterogeneidade do custo de entrada para a exportação entre os países explica em parte porque firmas parecidas têm probabilidades diferentes de se tornarem exportadoras por conta do país na qual estão localizadas. Neste sentido, o custo de entrada para exportação torna-se mais uma fonte de competitividade entre os países no comércio internacional.

Vários fatores podem explicar a variação do custo de entrada para exportação entre os países, há fatores mais concretos como impostos sobre a exportação ou taxas aduaneiras, mas também, como bem demonstrado pela literatura, assimetrias na qualidade das instituições 
funcionam como fontes de vantagem comparativa no comércio internacional. A fim de trazer alguma luz ao papel das instituições sobre esta nova fonte de competitividade, associamos o custo fixo de entrada para exportação encontrado para 72 países e a qualidade de algumas variáveis institucionais. Encontramos evidências de que quanto pior a classificação das instituições pelas firmas, maior é o custo de entrada para a exportação do país.

Em suma, nosso trabalho contribui com a literatura ao demonstrar que o custo fixo de entrada para a exportação deve ser compreendido como algo abrangente e não como uma singularidade de um país ou setor de atividade e que, sobretudo, este custo deve ser tratado como uma fonte de competitividade entre os países. Sendo assim, a redução do custo de entrada para a exportação deveria ser uma meta dos policy makers que almejam fomentar as exportações sem gerar distorções na economia. 


\section{A DESONERAÇÃO SOBRE A FOLHA DE PAGAMENTOS E SUA RELAÇÃO COM O COMÉRCIO EXTERIOR}

\subsection{INTRODUÇÃO}

Em dezembro de 2011, no âmbito do programa Brasil Maior, o governo então presidido por Dilma Rousseff substitui a contribuição patronal de $20 \%$ sobre a folha de pagamento por um imposto equivalente a um percentual do faturamento bruto anual. Tal medida tinha por objetivo aumentar a competitividade da indústria nacional, gerar empregos e aumentar a formalização da mão-de-obra. O mesmo governo também estabeleceu que eventuais déficits gerados por tal medida fossem cobertos pelo Tesouro Nacional.

Segundo relatório do governo chamado Plano Brasil Maior - Balanço Executivo - 2 anos produzido pela Agência Brasileira de Desenvolvimento Industrial (ABDI) e publicado em 2013:

\footnotetext{
O número de setores beneficiados com essa nova sistemática foi sucessivamente ampliado pelas Leis $12.715 / 12,12.794 / 13$ e $12.844 / 13$, alcançando o patamar de 42 setores.

[...]

Esses 42 setores representam $22 \%$ do total das exportações brasileiras, $59 \%$ das exportações de manufaturados e $19 \%$ da receita bruta total da economia. Além disso, empregam $32 \%$ dos trabalhadores celetistas e representam $24 \%$ da massa salarial. Estima-se que a redução de tributos proveniente desse esforço, em 2014, será da ordem de R \$24,7 bilhões. (ABDI, 2013, p. 11)
}

O objetivo deste ensaio é avaliar se a desoneração da folha de pagamento contribuiu para tornar os bens brasileiros mais competitivos, refletindo em queda das importações e aumento das exportações. Segundo Cuñat e Merlitz (2007) e Helpman e Itskhoki (2010), países que possuem um mercado de trabalho mais flexível e com menores encargos sociais são mais competitivos do que os seus concorrentes. Além disso, o relatório da ABDI citado anteriormente e o trabalho de Domingues et al. (2012) concluem que no Brasil a desoneração da folha de pagamentos impacta positivamente as exportações no curto prazo.

Utilizamos em nossa análise um painel de efeito fixo para produto conforme seu código NCM. Empregamos os dados de exportação e importação brasileiros disponibilizados pelo Ministério da Indústria, Comércio Exterior e Serviços (MDIC) em valor FOB (Free on Board), em peso (Kg) e em quantidade (unidade estatística da mercadoria) de janeiro de 2003 até dezembro de 2014 e dados da Pesquisa Industrial Anual (PIA) do IBGE de 2007 de intensidade do uso de mão-de-obra na produção de cada bem. Além disso, construímos a variável desoneração que é uma dummy que identifica a política. Vale notar que empregamos 
variações da variável de intensidade de mão-de-obra na produção e da variável desoneração a fim de mensurar a robustez de nossos resultados.

Basicamente, encontramos que as desonerações geraram uma queda estatisticamente significante da quantidade, do valor e do peso das importações. Porém, também foram responsáveis por uma queda estatisticamente significante em peso e em valores das exportações, o que pode ter sido reflexo de uma queda dos preços e não das quantidades exportadas. Portanto, o resultado da política, ao menos sobre a balança comercial, não foi tão eficaz quanto se esperava no momento do lançamento do programa. Somou-se à controversa eficácia da medida, o crescente desfalque fiscal nas contas públicas gerado pelas desonerações da folha, o que levou o governo a reverter a direção da medida em 2015, elevando as alíquotas dos impostos sobre a receita bruta.

O ensaio será apresentado da seguinte forma. Após esta breve introdução, na seção 3.2 discorremos sobre a literatura que relaciona mercado de trabalho e comércio internacional, bem como sobre trabalhos empíricos que analisam o impacto das desonerações da folha de pagamentos sobre a economia brasileira. Na seção 3.3 descrevemos a política de desoneração da folha de pagamentos. Na seção seguinte apresentamos os dados utilizados no ensaio. $\mathrm{Na}$ seção 3.5, explicamos o modelo econométrico adotado na análise. Em seguida, fazemos uma análise descritiva para melhor compreender o problema em questão. Na seção 3.7, apresentamos os resultados das nossas estimações. Por fim, na seção 3.8, concluímos o ensaio.

\subsection{REVISÃO DE LITERATURA}

Este ensaio se apoia na literatura que relaciona mercado de trabalho e comércio internacional. Grosso modo, o que a literatura nos diz é que países que possuem um mercado de trabalho mais flexível e com menores encargos sociais são mais competitivos do que os seus concorrentes.

Neste sentido, em termos teóricos, destacam-se trabalhos como de Donald Davis (1998) que constrói um modelo em que o mundo se divide entre EUA com salários flexíveis e a Europa com a política de salário mínimo. Na autarquia, na Europa há desemprego em função da política de salário mínimo e nos EUA não há desemprego porque o salário real pode cair a ponto de empregar toda a população. No momento em que estes blocos passam a fazer comércio entre si, a taxa de desemprego na Europa dobra, surgem desempregados nos EUA (embora em quantidade muito inferior ao encontrado na Europa) e os salários dos 
americanos sobem. Portanto, o comércio internacional força os europeus a incorrerem em um desemprego maior não só para sustentar seus maiores salários como também para sustentar os maiores salários dos americanos. Diante destes resultados, o autor conclui que mesmo quando o mercado de fatores é estritamente local, em presença de comércio, as instituições que vigoram apenas em nível nacional afetam o padrão global de alocação.

Costinot (2009) desenvolve um modelo que tenta explicar a origem das vantagens comparativas entre os países através do grau de cumprimento dos contratos no mercado de trabalho e da qualidade do estoque de mão-de-obra de cada país. Neste modelo, o mercado de trabalho apresenta contratos incompletos e, consequentemente, o trabalhador pode não cumprir o contrato de trabalho que estipula suas tarefas. Há a produção de dois tipos de bens: simples e complexos. A produção do bem complexo em relação ao simples requer uma quantidade maior de tarefas e uma maior divisão do trabalho e, consequentemente, uma dependência maior do cumprimento dos contratos de trabalho. Costinot conclui que o maior grau de cumprimento dos contratos de trabalho e níveis de educação mais elevados são fontes complementares de vantagens comparativas em indústrias mais complexas.

Ainda em termos teóricos, Helpman e Itskhoki (2010) constroem um modelo de comércio internacional de dois países e dois setores, sendo que um dos setores produz um produto homogêneo enquanto que o outro setor produz produtos diferenciados. Os países são exatamente iguais exceto pelos encargos sociais como custo de férias, custos de demissão, seguro-desemprego etc. Os autores concluem que ambos os países se beneficiam com o comércio. Todavia, o país com regras trabalhistas mais flexíveis ganha proporcionalmente mais que o país com regras mais rígidas. Desta forma, um mercado de trabalho flexível gera uma vantagem comparativa para o país, com uma parcela maior de firmas exportadoras e uma maior quantidade de produtos diferenciados na sua pauta de exportação em relação ao país com leis trabalhistas mais rígidas.

Cuñat e Merlitz (2007) constroem um modelo de comércio entre dois países, sendo um com leis trabalhistas flexíveis e o outro com leis trabalhistas rígidas. Neste modelo, na presença de choques, o produtor final do país com leis trabalhistas mais flexíveis pode realocar sua produção de forma a utilizar mais os produtos intermediários que ficaram mais produtivos depois do choque; isto não se aplica para o país com leis trabalhistas mais rígidas. Este comportamento confere ao país com leis trabalhistas mais flexíveis, em relação ao país com leis trabalhistas rígidas, uma vantagem comparativa que é maior quanto maior for a volatilidade da indústria. Os autores testam empiricamente este modelo e, de fato, concluem 
que os países com leis trabalhistas mais flexíveis concentram suas exportações relativamente mais em setores mais voláteis.

No caso de trabalhos utilizando dados brasileiros, há uma predominância de estudos avaliando o impacto das mudanças das leis trabalhistas ou dos encargos sociais sobre o mercado de trabalho. Neste sentido, os resultados encontrados são bastante ambíguos. Barros e Corseuil (2004), por exemplo, não encontram evidências de que a mudança nas leis trabalhistas imposta pela Constituição de 1988 tenha afetado os parâmetros da demanda por trabalho. Já Bosch, Goni e Maloney (2012) afirmam que a abertura comercial e a maior rigidez das leis trabalhistas foram responsáveis, respectivamente, pelo aumento de $1 \%$ e de $40 \%$ a $50 \%$ na informalidade no mercado de trabalho.

Fernandes e Menezes-Filho (2002), utilizando dados em painel da PIA (IBGE) de 1985 a 1995 e discriminando por ramo industrial, concluem que o aumento dos encargos sociais imposto pela Constituição de 1988 fez o salário médio cair e não apresentou impacto estatisticamente significante no nível de emprego.

Podemos citar, também, o trabalho de Fernandes, Gremaud e Narita (2004) que faz simulações através de um modelo de equilíbrio geral, ora diminuindo a carga tributária, ora alterando a base tributária com manutenção do nível de arrecadação. Grosso modo, as simulações apontam para uma melhora dos salários médios e um aumento do nível de emprego como resposta a uma redução da carga tributária. Porém, estes impactos, apesar de estatisticamente significativos, mostraram-se relativamente pequenos. Nesta mesma direção, o trabalho de Ulyssea e Reis (2006), também utilizando um modelo de equilíbrio geral, conclui que uma desoneração da folha de pagamentos faria o nível de desemprego cair, os salários médios se elevarem e o grau de informalidade se reduzir. Os resultados encontrados nestes dois últimos trabalhos podem estar superestimados segundo Paiva e Ansiliero (2009).

Ulyssea (2008) também encontra impactos modestos de uma política de desoneração da folha de pagamentos sobre os indicadores do mercado de trabalho, embora utilize um arcabouço diferente dos demais trabalhos. O autor adapta o modelo de matching de Acemoglu (2001) de dois setores, formal e informal, incorporando os principais tradeoffs que firmas e trabalhadores enfrentam ao decidirem em que setor ingressar. Sua conclusão é que quase todo o efeito de variações na alíquota de imposto sobre a folha recai sobre os salários dos trabalhadores. Portanto, uma política de desoneração da folha de pagamento tem um efeito positivo, mas muito pequeno sobre a taxa de desemprego e sobre o grau de formalização da mão-de-obra. 
Trabalhos atuais extrapolam a análise dos efeitos da desoneração da folha de pagamentos para além do mercado de trabalho e, portanto, apresentam forte confluência com nossa pesquisa. Domingues et al. (2012), por exemplo, utilizam um modelo de equilíbrio geral computável configurado para 60 setores, 117 produtos, 14 componentes de demanda final, capital e trabalho como fatores de produção, e dois setores de margem (comércio e transporte). As exportações setoriais respondem a curvas de demanda negativamente associadas aos custos domésticos de produção e positivamente afetadas pela expansão exógena da renda internacional, adotando-se a hipótese de país pequeno no comércio internacional. Neste modelo, uma desoneração da folha de pagamento sem nenhuma contrapartida para manter o equilíbrio fiscal (simulação 1) e uma desoneração que é neutra do ponto de vista fiscal (simulação 2) geram no longo prazo um efeito parecido na taxa de crescimento do PIB: uma elevação de $0,1 \%$. Além disso, os efeitos sobre investimento e exportações entre as duas simulações são bastante parecidos no curto prazo; o investimento cresce $0,29 \%$ e as exportações $1,83 \%$. Já no longo prazo, os resultados são diferentes. Em relação à simulação 1 , devido ao aumento do salário real que eleva o custo de produção, os investimentos e as exportações caem. Já simulação 2, há uma queda do salário real diminuindo os custos de produção, o que potencializa o efeito sobre as exportações, que é compensado por uma queda do consumo e do investimento do governo. Em termos de impactos setoriais, concluem que a desoneração da folha de pagamento da indústria beneficia o setor industrial em detrimento da agropecuária e dos serviços.

Nesta mesma linha, Paes (2012) estima o impacto da troca da contribuição patronal sobre a folha de pagamentos pela elevação da COFINS de modo a manter a neutralidade fiscal. O autor utiliza um modelo de equilíbrio geral que contempla uma família representativa e o lado produtivo com 57 firmas com mais importações, cada uma representando um setor da economia, calibrado com dados das Contas Nacionais de 2008. Do ponto de vista macroeconômico, os resultados são modestos: o emprego apresenta um pequeno ganho e há uma leve redução do uso do capital, mas sem efeitos mais robustos sobre o produto e o bem-estar. Por outro lado, há fortes impactos setoriais. A indústria passa a pagar menos impostos, o que é compensado pela elevação da carga tributária para os setores de serviços e agropecuária. Consequentemente, a realocação da tributação promove a redistribuição do produto e do emprego entre os diversos setores, com migração para os setores industriais em detrimento dos setores de serviços e agropecuária. 


\subsection{DESCRIÇÃO DA POLÍTICA DE DESONERAÇÃO}

Nos anos noventa, preocupados com o aumento da informalidade no mercado de trabalho brasileiro e suas consequências nefastas sobre o financiamento do sistema de Previdência Social, o governo iniciou a discussão sobre a desoneração da folha de pagamentos. Ao mesmo tempo, grupos de empresários pressionavam pela medida argumentando que seria uma forma de mitigar o elevado custo Brasil.

Neste contexto, as leis foram gradativamente migrando para a desoneração da folha, o que ocorreu a partir de 2011 e que é alvo de estudo deste ensaio. Em 1998 foi permitido que as contribuições sociais patronais fossem, de certa forma, flexibilizadas. Em 2003, permitiu-se que a contribuição patronal sobre a folha fosse substituída sobre um imposto sobre a receita ou sobre o faturamento.

Durante o governo Lula, como parte da proposta de reforma tributária apresentada pela PEC 233/2008, a desoneração voltou à pauta. Porém, assim como nos demais itens desta PEC, não houve consenso no Congresso, o que não permitiu que fosse aprovada.

Em seguida, em maio de 2011, já no governo de Dilma Rousseff, a questão da desoneração da folha voltou a ser discutida entre o governo e diversas centrais sindicais na chamada "Mesa de Negociação Permanente". O governo visava com a medida melhorar a competitividade dos setores intensivos em mão-de-obra, fomentar os investimentos, criar empregos e aumentar a formalização. Acordou-se que a contribuição previdenciária patronal seria substituída por um imposto sobre o faturamento ou sobre as vendas. As alíquotas deste imposto poderiam diferir entre os setores de atividade, este imposto compensatório incidiria sobre as importações, mas não sobre as exportações e o Tesouro Nacional seria responsável por compensar possíveis perdas de arrecadação da Previdência. Isto porque, no líquido, esta mudança de tributação representava uma redução de imposto.

Desta forma, em agosto de 2011 o governo anunciou o Plano Brasil Maior que visava estimular o investimento e o comércio exterior, dar competitividade à indústria nacional e fomentar o mercado interno. Através da MP 540 de agosto de 2011 (que posteriormente se tornaria a Lei 12.546 com vigência a partir de dezembro de 2011) o governo substitui a contribuição patronal de $20 \%$ sobre a folha de pagamento por um imposto calculado pela porcentagem sobre o faturamento bruto anual, descontada a receita com exportação, para um pequeno grupo de atividades. Segundo esta Lei, o setor de serviços de tecnologia da informação e de tecnologia da informação e comunicação (TI e TIC) contribuiria com 2,5\% da receita e as indústrias moveleiras, de confecções e de artefatos de couro e calçados 
contribuiriam com $1,5 \%$ da receita. Vale notar que falar em desoneração de setor industrial é uma generalização, pois a desoneração foi feita por produto industrial conforme sua classificação na Tabela de Incidência do Imposto sobre o Produto Industrializado (TIPI).

Em abril de 2012, a MP 563 (que posteriormente virou a Lei 12.715, a qual passou a vigorar em agosto de 2012) ampliou a desoneração para 14 setores, com a inclusão de têxtil, plásticos, material elétrico, autopeças, fabricação de ônibus, fabricação de navios, fabricação de aviões, bens de capital, mecânico, call centers, design houses e hotéis. Além disso, a Lei reduziu as alíquotas sobre a receita para $1 \%$ no caso dos bens industriais e $2 \%$ no caso dos serviços.

A MP 563 foi alterada através do Projeto de Lei de Conversão 18, de modo que a Lei 12.715, a partir de janeiro de 2013, passou a desonerar também as prestadoras de serviços de transporte rodoviário coletivo de passageiros aplicando uma alíquota de $2 \%$, enquanto os setores de transporte aéreo, marítimo, fluvial e navegação de apoio, e também, outros segmentos industriais como a produção de aves, suínos e derivados, pães e massas, fármacos e medicamentos, brinquedos, pedras e rochas ornamentais, manutenção e reparos de aviões foram desonerados aplicando uma alíquota de $1 \%$.

Ao mesmo tempo, a MP 582 de setembro de 2012 (que passou a vigorar em janeiro de 2013 e que, posteriormente, foi transformada na Lei 12.794), aplicando uma alíquota de 1\%, ampliou a desoneração da folha para as indústrias de pescado, equipamentos médicos e odontológicos, bicicletas, equipamento ferroviário, pneus e câmaras de ar, papel e celulose, vidros, fogões, refrigeradores e lavadoras, cerâmicas, tintas e vernizes, construção metálica, fabricação de ferramentas, fabricação de forjados de aço, parafusos, porcas e trefilados e instrumentos óticos. Neste momento, a desoneração passou a contemplar 40 setores de atividade.

Ainda em 2013, a MP 610 (que se tornou a Lei 12.844 de julho de 2013) desonerou os segmentos de suporte técnico de informática e construção civil aplicando a estes setores uma alíquota de $2 \%$. Ao mesmo tempo, os setores de comércio varejista, manutenção e reparação de embarcações, borracha, obras de ferro fundido, ferro ou aço, cobre e suas obras, obras diversas de metais comuns, reatores nucleares, máquinas e instrumentos mecânicos e suas partes foram desonerados, aplicando-se uma alíquota de $1 \%$. A partir de janeiro de 2014 , os setores de transporte rodoviário de carga, transporte ferroviário de cargas, carga, descarga e armazenagem de contêineres e empresas jornalísticas foram desonerados, aplicando-se uma alíquota de $1 \%$. Já os setores de transporte metroviário de passageiros, empresas de 
construção e de obras em infraestrutura foram desonerados, aplicando uma alíquota de $2 \%$. Vale notar que a desoneração é vigente até 31/12/2014.

A desoneração da folha, que começou em 2011 incidindo sobre 4 setores, passou a contemplar 56 em 2014. Porém, à medida que a desoneração foi sendo ampliada e a indústria foi perdendo tração em função da crise econômica, a renúncia fiscal foi aumentando, passando de R \$3,6 bilhões em 2012 para R \$12,3 bilhões em 2013 e para R \$21,6 bilhões em 2014. A partir de dezembro de 2015, diante da necessidade de ressarcir os cofres públicos, o governo eleva as alíquotas incidentes sobre a receita das empresas. De modo geral, os que pagavam $1 \%$ e $2 \%$ passaram a pagar $2,5 \%$ e $4,5 \%$, respectivamente.

Neste ensaio, nossa avaliação vai até 31/12/2014, ápice da política de desoneração, a qual foi sendo gradualmente desfeita nos anos seguintes.

\subsection{DADOS}

\subsubsection{Exportação e Importação}

Para as análises a seguir, utilizamos os dados públicos de exportação e importação brasileiros compilados pelo Ministério da Indústria, Comércio Exterior e Serviços (MDIC). Embora a primeira lei de desoneração tenha entrado em vigor em dezembro de 2011, utilizaremos dados desde janeiro de 2003 até dezembro de 2014. Desta forma temos quase dez anos de observações anteriores ao início do processo de desoneração da folha, o que permite identificar com robustez a tendência no tempo das variáveis estudadas.

A base utilizada por nós para as exportações e importações brasileiras contém as informações: mês, ano, o código Nomenclatura Comum do MERCOSUL (NCM) de oito dígitos do produto, quantidade na unidade de medida estatística da mercadoria, peso líquido em quilogramas e valor em dólares FOB (Free On Board). A Tabela NCM contém 10.046 produtos, e no período analisado por nós, o Brasil exportou 9.293 e importou 9.696 variedades de produtos (códigos NCM). Vale notar que a classificação NCM e a classificação TIPI $^{24}$ (Tabela de Incidência do Imposto sobre Produtos Industrializados) coincidem, o que facilita a análise, uma vez que a desoneração foi feita, predominantemente, por produto classificado na TIPI.

\footnotetext{
${ }^{24}$ http://idg.receita.fazenda.gov.br/acesso-rapido/legislacao/documentos-e-arquivos/tipi
} 


\subsubsection{Intensidade do fator trabalho}

Como no líquido a substituição do pagamento patronal sobre a folha de pagamentos pelo tributo vinculado à receita representa uma queda de imposto, provavelmente, quanto mais um produto for trabalho-intensivo, mais a empresa que o produz será beneficiada pela desoneração da folha de pagamento. Desta forma, interagimos a desoneração com a variável de intensidade de trabalho para uma estimação mais precisa dos efeitos da desoneração sobre o comércio exterior brasileiro.

Contudo, lamentavelmente, não possuímos a informação sobre a quantidade relativa de capital e trabalho empregada na produção de cada produto. Desta forma, utilizamos como proxy para a intensidade relativa de trabalho na produção a razão do gasto total com pessoal sobre uma proxy do gasto total com pessoal e capital. Estes dados são retirados da Pesquisa Industrial Anual (PIA), com base na Classificação Nacional de Atividades Econômicas (CNAE). Esta pesquisa é realizada pelo IBGE e é publicada anualmente.

Utilizamos neste trabalho as seguintes variáveis ${ }^{25}$ : gasto total com pessoal $(g p)$, gasto e despesas totais $(g t)$, receita total $(r e c)$ e valor adicionado ${ }^{26}(v a)$. Com estas variáveis construímos três estimativas para o grau de intensidade do fator trabalho utilizado na produção de cada produto. São elas: $g p g t=g p / g t, g p r e c=g p / r e c$ e $g p v a=g p / v a$. Apesar de gpgt nos parecer uma proxy mais intuitiva para o uso relativo de trabalho na produção, há uma grande chance de haver erros de mensuração do gasto com capital, por isso construímos as outras duas estimativas.

Vale notar que a correspondência entre os dados de exportação e importação com os dados da PIA não é direta. A classificação dos produtos no comércio exterior segue a NCM, enquanto que os dados da PIA utilizados por nós seguem a Classificação Nacional de Atividades Econômicas $\left(\mathrm{CNAE}^{27}\right)$. A correspondência entre as duas é dada pela Comissão Nacional de Classificação $\left(\mathrm{CONCLA}^{28}\right)$.

\footnotetext{
${ }^{25}$ Todos estão expressos em Mil Reais.

${ }^{26} \mathrm{O}$ valor adicionado é calculado pelo IBGE através da receita bruta total subtraída dos custos operacionais industriais (matérias-primas, combustível, energia elétrica, serviços de terceiros, etc).

${ }^{27} \mathrm{O}$ sistema de codificação da CNAE segue uma ordem de subdivisão conforme o nível de detalhamento. A primeira classificação e a mais abrangente é a "Seção", a qual é formada por um código alfabético de um dígito, em seguida vem a "Divisão" que é um código de dois dígitos, depois vem o "Grupo" com três dígitos, seguida da "Classe" com quatro dígitos mais DV e, por último, a "Subclasse" com sete dígitos.

${ }^{28} \mathrm{http} / / / \mathrm{cnae} . \mathrm{ibge.gov} . \mathrm{br} / \mathrm{classificacoes/correspondencias/atividades-economicas}$
} 
Os dados da PIA utilizados por nós estão disponíveis apenas ao nível de Divisão. $\mathrm{Na}$ indústria, há 29 categorias de divisão, conforme a Tabela 25, a seguir. Portanto, há mais de um código NCM correspondente ao mesmo valor calculado utilizando os dados da PIA.

Tabela 25 - Número de categorias da indústria por Nível

\begin{tabular}{llr}
\hline Nível & Código & Número de Categorias da Indústria \\
\hline Seção & Alfabético de 1 dígito & 2 \\
Divisão & Numérico de 2 dígitos & 29 \\
Grupo & Numérico de 3 dígitos & 111 \\
Classe & Numérico de 4 dígitos & 274 \\
\hline
\end{tabular}

Fonte: IBGE, Diretoria de Pesquisas, Coordenação de Indústria.

A PIA, como o próprio nome diz, é uma pesquisa anual, portanto as estimativas de intensidade de uso de fator trabalho na produção variariam a cada ano. Porém, esta variação é modesta para a grande maioria dos mais de dez mil tipos de produtos visto que as revoluções tecnológicas são raras, principalmente aquelas que são espraiadas em todas as firmas. Desta forma, fixamos para todos os anos da amostra a relação entre capital e trabalho para cada produto igual àquela presente na PIA de 2007. Este procedimento também evita que utilizemos uma relação de capital e trabalho influenciada pela desoneração, o que torna nossa análise mais conservadora.

\subsubsection{Desoneração}

A variável de interesse neste ensaio foi a desoneração e, em função da forma como a desoneração foi feita, ela apresenta variabilidade em duas dimensões, tanto em termos de cross-section (produto) quanto no tempo. A variável desoneração foi tratada como uma dummy que apresenta valor igual a 1 desde quando o produto, ou seja, o código NCM é desonerado até 31/12/2014, e zero, caso contrário.

De janeiro de 2003 até novembro de 2011 a variável desoneração é igual a zero para todos os produtos em termos de código NCM. A partir de dezembro de 2011 passa a ser igual a 1 para os produtos desonerados, cuja quantidade é de 86 em dezembro de 2011, 401 em abril de 2012, 2.835 em agosto de 2012, 3.879 em janeiro de 2013, 3.916 em julho de 2013 e 3.922 em janeiro de 2014, conforme Tabela ${ }^{29}$ a seguir.

\footnotetext{
${ }^{29}$ Vale notar que o total de códigos NCM englobam todos os setores de atividade da economia, e não apenas a indústria.
} 
Tabela 26 - Quantidade de produtos desonerados ao longo do tempo

\begin{tabular}{lccc}
\hline Data de vigência & Novos produtos desonerados & Quantidade total de produtos desonerados & \% do Total de produtos NCM \\
\hline Dez-11 & 86 & 86 & $0.9 \%$ \\
Abr-12 & 315 & 401 & $4.0 \%$ \\
Ago-12 & 2434 & 2835 & $28.2 \%$ \\
Jan-13 & 1044 & 3879 & $38.6 \%$ \\
Jul-13 & 37 & 3916 & $39.0 \%$ \\
Jan-14 & 6 & 3922 & $39.0 \%$ \\
\hline
\end{tabular}

Fonte: Autoria própria

Além disso, separamos a desoneração em três diferentes variáveis a fim de capturar a alteração de magnitude da tarifa, já que de dezembro de 2011 a julho de 2012 a contribuição para os produtos industriais era de 1,5\% da receita, mas a partir de agosto de 2012 passou a ser de $1,0 \%$. Porém todas as 3 variáveis mantiveram a mesma lógica, são dummies iguais a 1 para os produtos (códigos NCM) desonerados e zero, caso contrário. A grande diferença entre as variáveis é sua extensão no tempo.

A primeira variável, que chamamos $T_{1}$, é uma dummy igual a 1 para 86 produtos de dezembro de 2011 a março de 2012 e igual a 1 para 401 produtos de abril de 2012 a julho de 2012. Esta variável se refere a desoneração que cobra como imposto compensatório à desoneração da folha $1,5 \%$ sobre a receita para os produtos industriais. A segunda variável, que chamamos $T_{2}$, é uma dummy igual a 1 para os mesmos 401 produtos desonerados em $T_{1}$, porém no período de agosto de 2012 a 31/12/2014. A terceira variável, que chamamos $T_{3}$, é uma dummy igual a 1 para os produtos que foram desonerados de agosto de 2012 a 31/12/2014, mas que são diferentes dos 401 produtos já abordados por $T_{2}$.

\subsection{METODOLOGIA}

Fizemos uma estimação em painel de efeito fixo para produto conforme seu código NCM. Embora sejam 10.046 produtos na tabela NCM, utilizamos na estimação apenas os produtos de códigos NCM que estiveram presentes na balança comercial brasileira do período de 2003 a 2014 (9.293 produtos para exportação e 9.696 produtos para importação). Portanto, é uma amostra selecionada por produto já transacionado com o exterior. Como nossos dados eram mensais, a exportação ou importação de alguns produtos em determinados meses e anos podia assumir valores iguais a zero, o que impediu a análise da regressão no logaritmo. Sendo assim, nossa regressão foi estimada no nível. A equação do modelo é descrita abaixo: 


$$
\begin{gathered}
y_{N C M, t}=\alpha+\beta_{1} P_{N C M, t} D_{N C M, t}+\beta_{2} P_{N C M, t} D_{N C M, t} L_{C N A E, 2007}+\beta_{3} P_{N C M, t} L_{C N A E, 2007}+\beta_{k} X_{k, N C M, t} \\
+\varepsilon_{N C M, t}
\end{gathered}
$$

Incluindo efeitos fixos para códigos NCM de produtos em (1), temos:

$$
y_{N C M, t}=\alpha+c_{N C M}+\beta_{1} P_{N C M, t} D_{N C M, t}+\beta_{2} P_{N C M, t} D_{N C M, t} L_{C N A E, 2007}+\beta_{k} X_{k, N C M, t}+\varepsilon_{N C M, t}
$$

Neste modelo, $y_{N C M, t}$ é o vetor de exportação ou importação para o produto NCM no período $t$, que neste caso é composto por mês e ano, $\alpha$ é a constante, $c_{\mathrm{NCM}}$ é o vetor de efeitos fixos dos produtos (códigos NCM), $P_{N C M, t}$ é uma dummy para cada código NCM, $D_{N C M, t}$ é a variável desoneração que conforme descrito acima assume valor 1 para os códigos NCM desonerados do momento da desoneração até 31/12/2014 e zero nos casos contrários; chamamos $P_{N C M, t} D_{N C M, t}$ de produto desonerado e o abreviamos pela letra $t ; L_{C N A E, 2007}$ é a relação entre uso do fator trabalho sobre o total de fatores fixados no ano de 2007 conforme o grupo CNAE correspondente ao código NCM; $X_{k, N C M, t}$ são as demais variáveis de controle e, finalmente, $\varepsilon_{N C M, t}$ é o vetor de erros aleatórios.

Vale notar que utilizamos três alternativas para a variável $y_{N C M, t}$ : as exportações e importações em quantidade na unidade de medida estatística da mercadoria, em peso líquido em quilogramas e em valor em dólares ${ }^{30}$ FOB (Free On Board). Como qualquer redução de imposto, a desoneração da folha contribui para a queda dos preços dos bens desonerados - os tornando mais competitivos internacionalmente - o que consequentemente, aumenta a quantidade exportada e reduz a quantidade importada destes bens. A análise do valor FOB das exportações pode ficar prejudicada dado que o efeito preço e o efeito quantidade se neutralizam. Já a análise do valor FOB das importações sofre apenas o efeito quantidade, o que permite uma análise mais clara.

Avaliamos também as exportações e importações em quantidade na unidade de medida estatística da mercadoria, o que elimina o efeito direto de preço na análise. Se por um lado este é um aspecto positivo, principalmente, para a análise das exportações, por outro, gera o problema de que todos os bens passam a ter o mesmo peso no cálculo, visto que o preço funcionava como uma ponderação dos valores dos bens. Sem este "ponderador", a exportação de um avião tem o mesmo peso que uma tonelada de soja. Avaliamos também as exportações e importações em peso líquido em quilogramas. Esta métrica apresenta um

\footnotetext{
${ }^{30}$ Não deflacionamos os valores de importação e exportação porque eles estão em dólares e a inflação no período nos EUA foi praticamente zero.
} 
balanço de vantagens e desvantagens bem parecido com a da quantidade na unidade de medida estatística da mercadoria.

Em suma, a desoneração, coeteris paribus, deve aumentar a quantidade e o valor exportado dos bens exportados pelo Brasil. Com relação às importações, a desoneração possivelmente tornará os bens nacionais mais competitivos, o que deve reduzir a demanda por bens importados.

Como controles, utilizamos dummies de ano, dummies de mês e dummies para a interação entre mês e ano, que foram responsáveis por controlar, por exemplo, os efeitos da variação cambial e do nível de atividade sobre as exportações e importações, entre outras coisas.

A fim de avaliar a robustez dos resultados, utilizamos três alternativas para a variável $L_{C N A E, 2007}: g p g t=g p / g t, g p r e c=g p / r e c$ e $g p v a=g p / v a$ e separamos a desoneração em 3 momentos: $T_{1}, T_{2}$ e $T_{3}$.

\subsection{ANÁLISE DESCRITIVA}

Uma primeira análise do efeito da desoneração sobre o comércio exterior brasileiro consistiu em comparar o crescimento das exportações e importações do grupo dos bens desonerados versus o grupo dos não desonerados. Tanto para as exportações quanto para as importações, comparamos o diferencial de crescimento médio nos três anos anteriores à desoneração (2009 a 2011) em relação aos 3 anos de desoneração estudados (2012 a 2014).

Como se pode notar pela Figura 11, a seguir, o crescimento das exportações dos bens desonerados cai menos do que para os bens não desonerados em termos de valor e quantidade. Em relação ao peso, enquanto para os bens desonerados há crescimento para os bens não desonerados registrou-se uma queda. 
Figura 11 - Diferencial de crescimento das Exportações Brasileiras (média de 2012 a 2014 - média de 2009 a 2011)

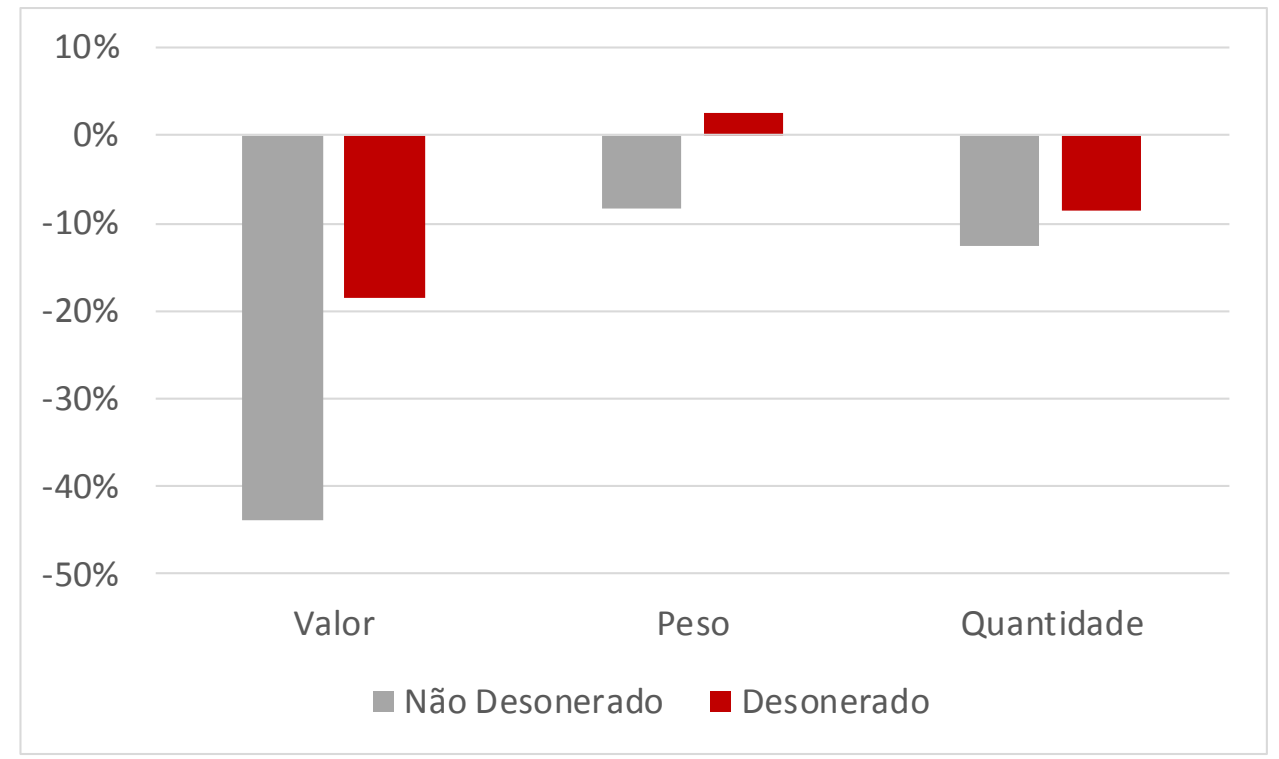

Fonte: Autoria própria

A análise das importações, de acordo com a Figura 12, mostra que os bens desonerados apresentaram uma queda da taxa de crescimento em relação ao peso e quantidade mais acentuada do que os bens não desonerados. Todavia, em termos de valor, o grupo desonerado caiu menos do que o grupo não desonerado.

Figura 12 - Diferencial de crescimento das Importações Brasileiras (média de 2012 a 2014 - média de 2009 a

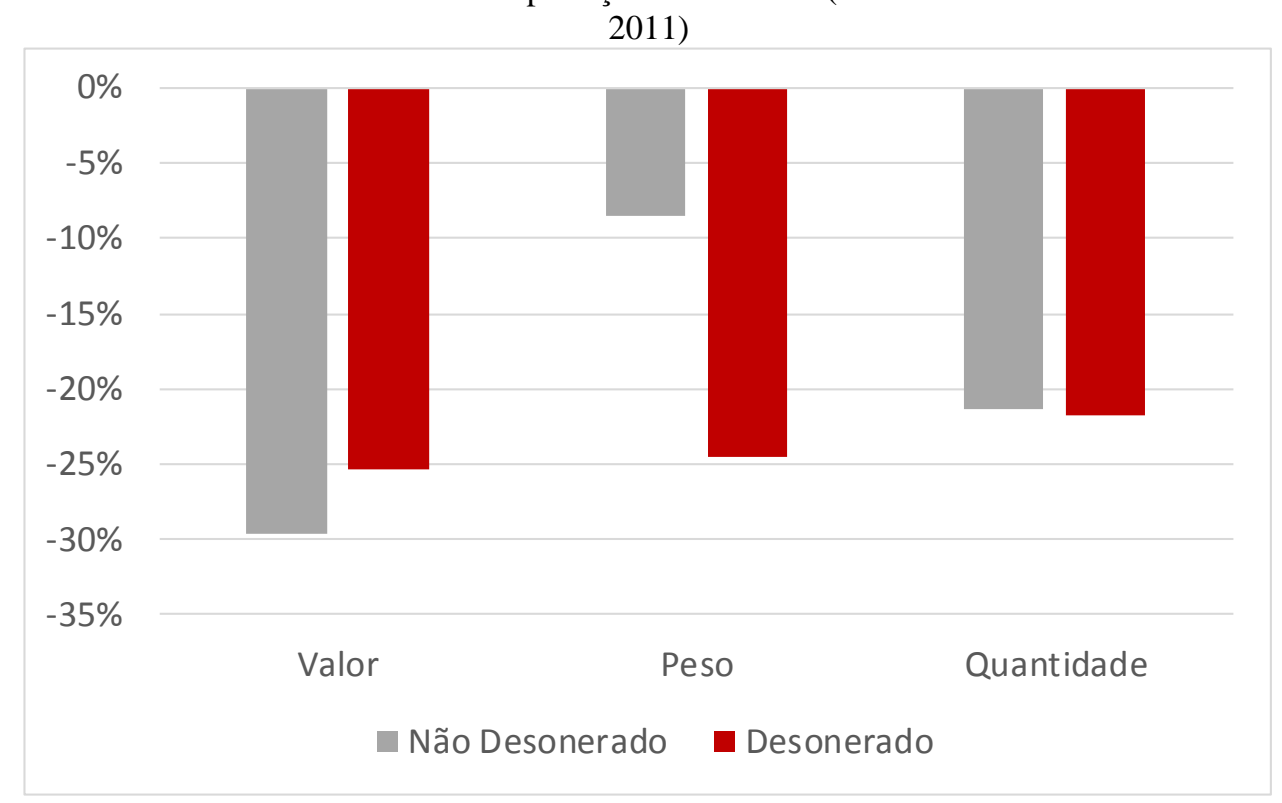

Fonte: Autoria própria 
Apesar de os resultados encontrados acima serem sugestivos, eles não expressam o efeito fidedigno da desoneração da folha sobre o comércio exterior brasileiro. Isto porque o processo de desoneração começou em dezembro de 2011 e, de lá até janeiro de 2014, diversos produtos foram sendo incorporando ao longo do tempo ${ }^{31}$. Este fator torna o grupo dos bens desonerados e dos bens não desonerados variáveis ao longo do tempo, enquanto a análise gráfica acima considera como grupo desonerado os bens que foram desonerados independentemente de quando isso ocorreu e como grupo não desonerado os bens que nunca foram desonerados.

Outra análise interessante é a relação existente entre o diferencial de crescimento das exportações e importações entre o período anterior e posterior à desoneração por nível de intensidade do fator trabalho utilizado na produção. Nossa suposição é de que quanto mais um setor for mão-de-obra intensivo mais ele deve ter sido beneficiado pela desoneração da folha de pagamento e, portanto, maior deve ter sido o ganho de suas exportações e mais suas importações devem ter perdido espaço.

Sendo assim, respeitando a classificação na divisão da CNAE (29 grupos), correlacionamos o diferencial de crescimento médio das exportações ou importações no período anterior à desoneração (2009 a 2011) e posterior à desoneração (2012 a 2014) com a intensidade do fator trabalho utilizado na produção dos setores, conforme figuras a seguir:

Figura 13 - Exportação de desonerados

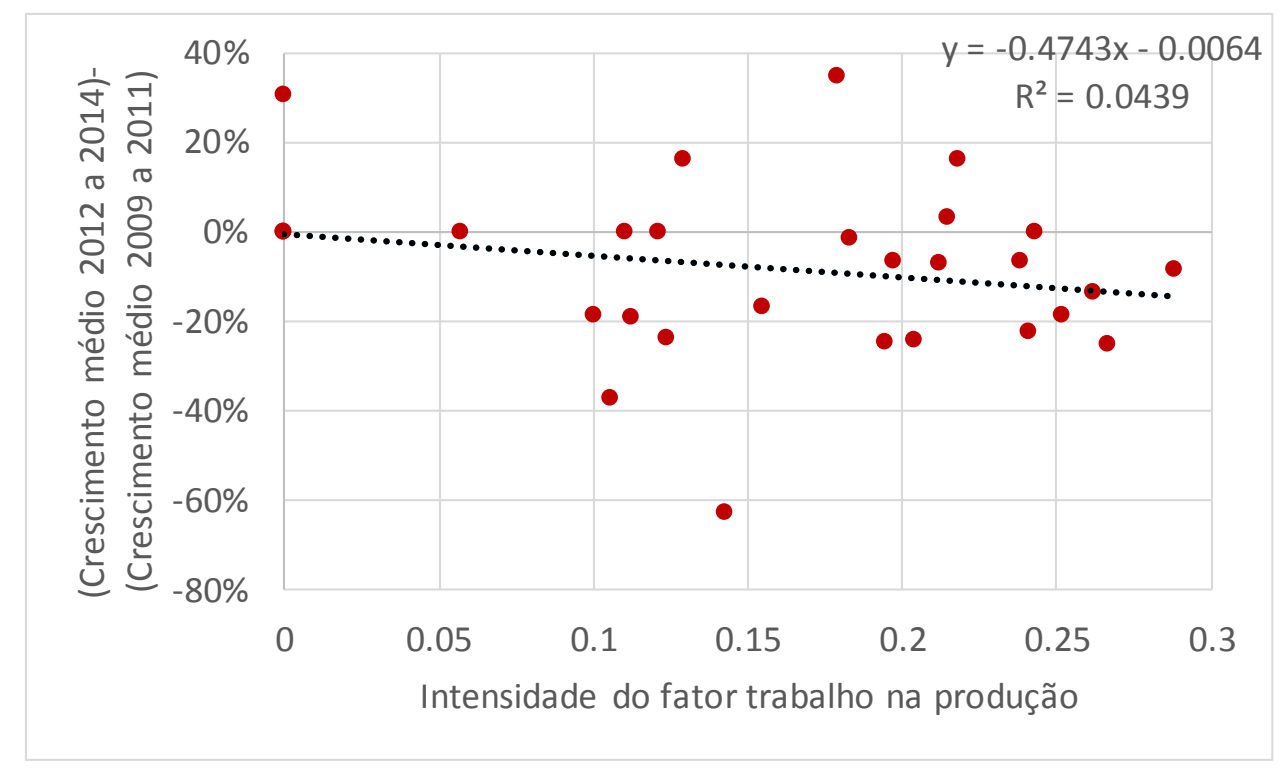

Fonte: Autoria própria

\footnotetext{
${ }^{31}$ Vide Tabela 2
} 
Figura 14 - Exportação de não desonerados

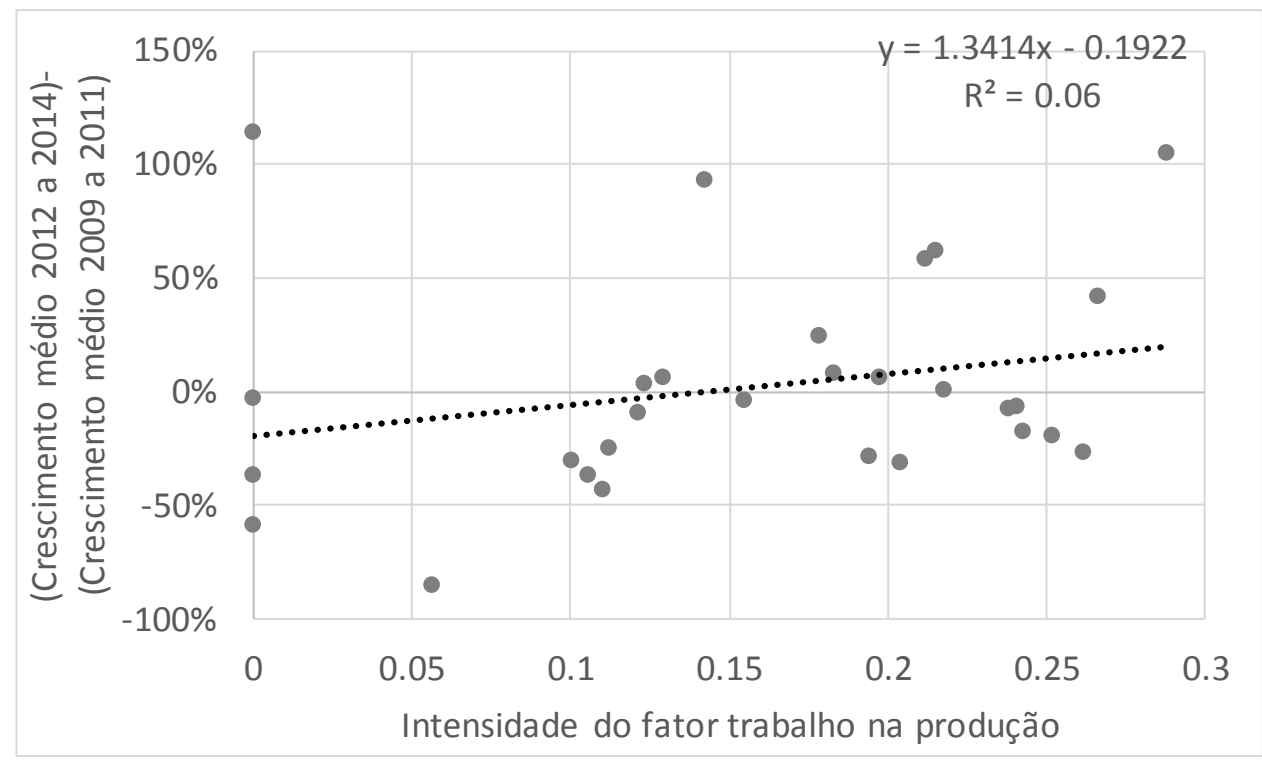

Fonte: Autoria própria

Com relação à exportação, notamos que quanto maior a intensidade do fator trabalho, maior foi o crescimento das exportações para o grupo dos bens não desonerados. Já para o grupo dos bens desonerados, notamos que quanto maior a intensidade do fator trabalho utilizado na produção do bem, menor foi o crescimento das exportações. Este resultado sugere que a desoneração da folha não apresentou o efeito de estimular as exportações.

Figura 15 - Importação de desonerados

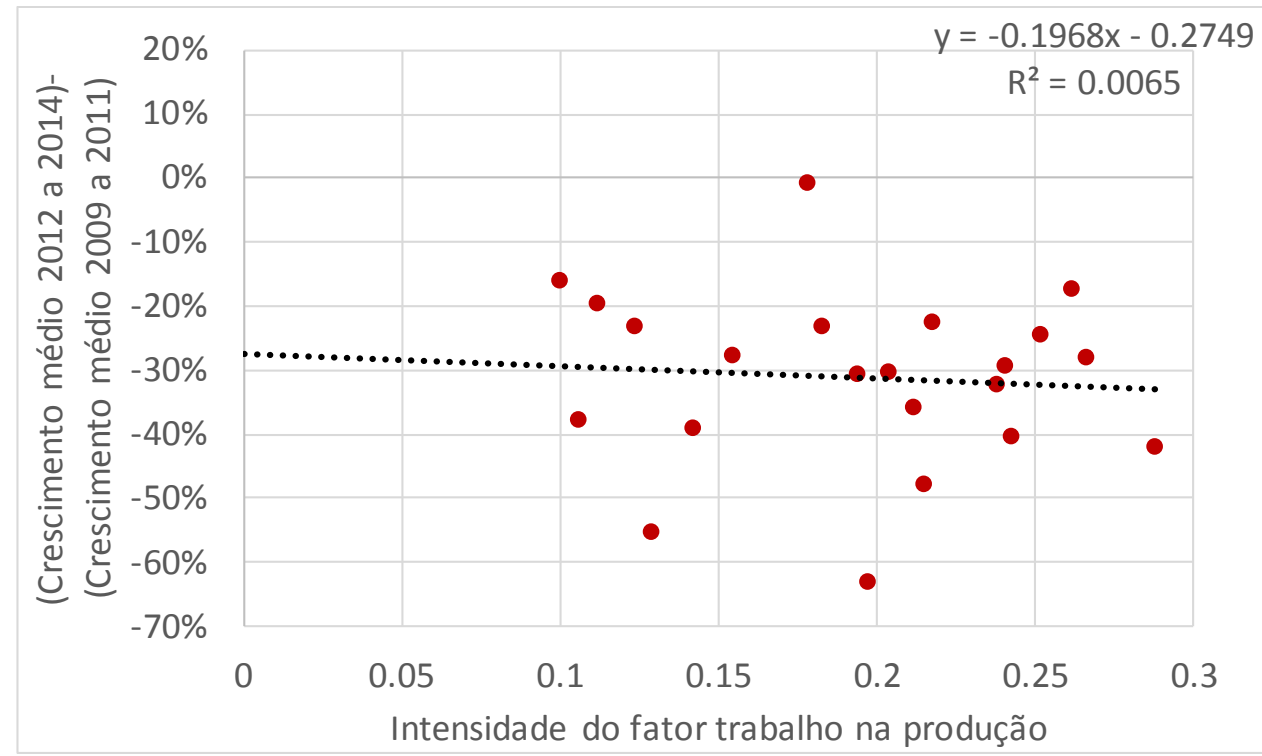

Fonte: Autoria própria 
Figura 16 - Importação de não desonerados

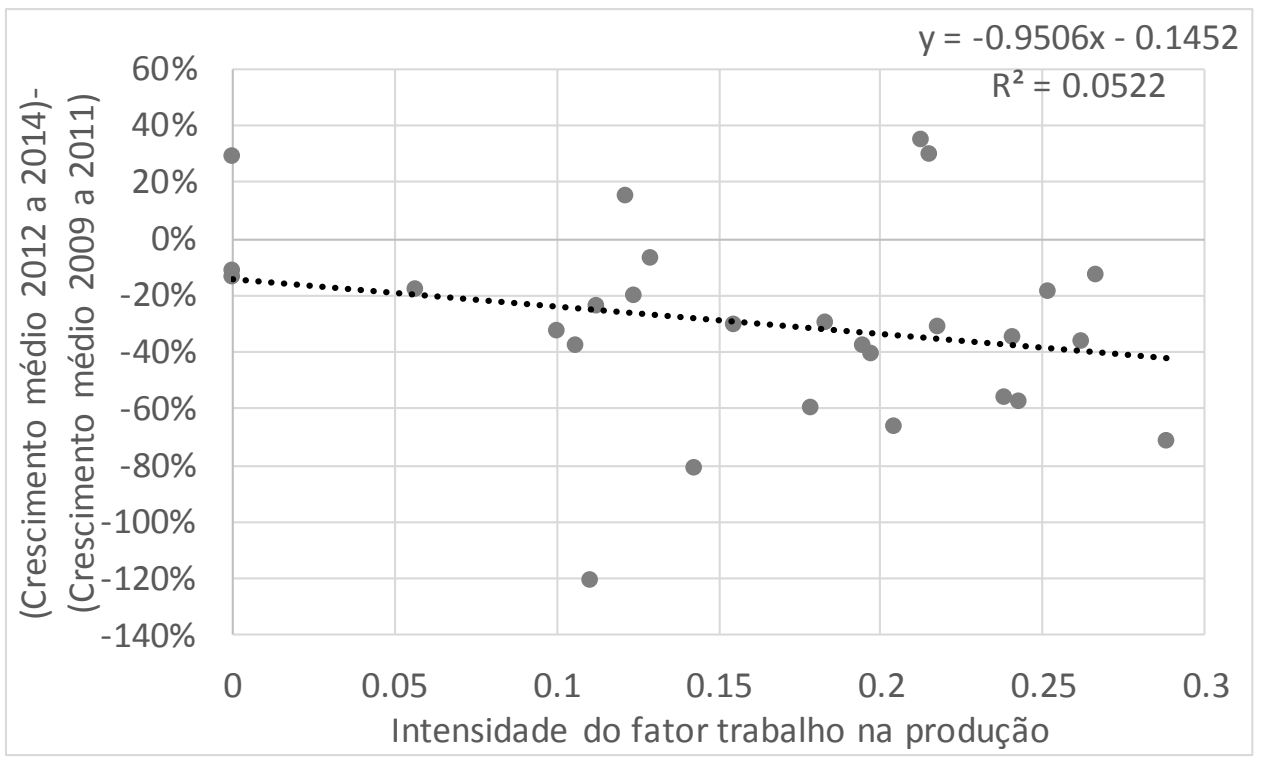

Fonte: Autoria própria

Com relação às importações, o efeito é inverso, ou seja, quanto mais mão-de-obra intensiva for um setor, menor é seu crescimento em comparação com o passado. Porém, esta relação é mais intensa dentre os bens que não foram desonerados do que os bens desonerados. Novamente, há indícios de que a desoneração não foi responsável pela queda das importações.

\subsection{RESULTADOS}

Como mencionamos na seção de Metodologia, analisamos o impacto das desonerações sobre três tipos de indicadores de exportação e importação: o valor FOB (valor), a quantidade na unidade de medida estatística da mercadoria (quantidade) e o peso líquido em quilogramas (peso). As análises das três variações de indicadores são complementares, uma vez que cada uma apresenta vantagens e desvantagens, conforme descrevemos na seção Metodologia.

\subsubsection{Impacto da desoneração sobre o total das exportações e importações}

De acordo com a Tabela 27, a seguir, as desonerações tiveram um impacto estatisticamente significante e negativo em relação ao valor e peso dos bens exportados, e não apresentaram efeito sobre a quantidade exportada. Mais especificamente, as exportações de um bem desonerado em relação aos demais, apresentou, na média, um recuo de $\mathrm{R} \$ 559$ mil e, em termos de peso, uma queda de 2.309 toneladas. Vale ressaltar que, como mencionamos 
anteriormente, a avaliação do impacto das desonerações sobre o valor FOB das exportações reflete tanto o efeito preço quanto o efeito quantidade. Portanto, uma queda do valor exportado pode refletir uma queda de preço que não foi mais que compensada por um aumento na quantidade exportada.

Em relação às importações, a desoneração apresentou um efeito estatisticamente significante, negativo e espraiado no valor, na quantidade e no peso dos bens que tiveram seu similar nacional desonerado. Isto é, os bens importados que foram desonerados domesticamente apresentaram um recuo de suas importações equivalente a 355 mil quantidades, $\mathrm{R} \$ 372$ mil e 422 toneladas.

Tabela 27 - Impacto das desonerações sobre exportação e importação

\begin{tabular}{|c|c|c|c|c|c|c|}
\hline \multirow[b]{3}{*}{ Variável } & 1 & 2 & 3 & 4 & 5 & 6 \\
\hline & \multicolumn{3}{|c|}{ Exportação } & \multicolumn{3}{|c|}{ Importação } \\
\hline & quantidade & valor & peso & quantidade & valor & peso \\
\hline produto desonerado & $-0,09$ & $-0,56 * * *$ & $-2309 * * *$ & $-0,35 * * *$ & $-0,37^{* * *}$ & $-422 * * *$ \\
\hline efeito fixo para NCM & $\operatorname{sim}$ & $\operatorname{sim}$ & $\operatorname{sim}$ & $\operatorname{sim}$ & $\operatorname{sim}$ & $\operatorname{sim}$ \\
\hline dummy mês & $\operatorname{sim}$ & $\operatorname{sim}$ & $\operatorname{sim}$ & $\operatorname{sim}$ & $\operatorname{sim}$ & $\operatorname{sim}$ \\
\hline dummy ano & $\operatorname{sim}$ & $\operatorname{sim}$ & $\operatorname{sim}$ & sim & $\operatorname{sim}$ & $\operatorname{sim}$ \\
\hline dummy interação mês e ano & $\operatorname{sim}$ & $\operatorname{sim}$ & $\operatorname{sim}$ & $\operatorname{sim}$ & $\operatorname{sim}$ & $\operatorname{sim}$ \\
\hline cons & 0,11 & $3,55^{* * *}$ & $11985^{* * *}$ & $1,39 * * *$ & $2,60 * * *$ & $2166 * * *$ \\
\hline no de observações & 382111 & 710422 & 382111 & 931036 & 931036 & 931036 \\
\hline $\mathrm{R}^{2}$ & 0,001 & 0,002 & 0,001 & 0,001 & 0,008 & 0,001 \\
\hline $\mathrm{n}$ o de NCM & 9248 & 9248 & 9248 & 9674 & 9674 & 9674 \\
\hline
\end{tabular}

* signficante a $10 \%$, ** significante a $5 \%$ e $* * *$ significante a $1 \%$

Quantidade e valor expressos em milhões, e peso em toneladas

Fonte: Autoria própria

\subsubsection{Impacto da desoneração controlando por intensidade de mão-de-obra na produção}

A fim de controlar pela intensidade do uso do fator trabalho utilizado na produção do bem, restringimos nossa amostra a apenas os bens que apresentam esta informação reportada na PIA, ou seja, a amostra atual excluiu, por exemplo, o setor agrícola, pecuário e extrativo mineral. Nossa hipótese foi de que, dentre os bens desonerados, os mais intensivos em mãode-obra foram os mais beneficiados pela política de desoneração da folha.

Os resultados desta estimação estão reportados na Tabela 28. Nota-se que, em relação às exportações, a desoneração apresentou efeito estatisticamente significante apenas para a variável valor (coluna 2). Se por um lado o valor das exportações apresentou uma resposta estatisticamente significante à desoneração, com o coeficiente da desoneração representando um incremento de US\$2,07 milhões no valor das exportações do bem desonerado, por outro, 
o coeficiente que multiplica a intensidade do fator trabalho para os bens desonerados (tgpgt) indica que quanto mais o produto desonerado for mão-de-obra intensiva menor será o valor exportado. Dado que o valor médio da variável gpgt para os bens desonerados é 0,2 , então, o valor médio total do impacto da desoneração no valor das exportações (efeito somado de desoneração e tgpgt) é de queda de praticamente um milhão de dólares. Portanto, na média, as desonerações impactaram negativamente o valor exportado dos bens desonerados, o que vai ao encontro do resultado da subseção anterior. Além disso, quanto mais um bem desonerado for intensivo em mão-de-obra, mais negativo será este impacto. É importante relembrar mais uma vez que uma queda do valor das exportações pode representar uma queda nos preços que não é compensada com um aumento da quantidade exportada.

Com relação às importações, as desonerações não apresentam efeito estatisticamente significante sobre a quantidade nem sobre o valor das importações. Todavia, com relação à variável peso, as desonerações provocam uma queda estatisticamente significante equivalente a 594 toneladas do bem importado cujo produto par foi desonerado domesticamente (coluna 6). Vale notar que os coeficientes referentes à interação entre desoneração e a intensidade do fator trabalho, embora negativos, não influenciam de forma estatisticamente significante as importações.

Tabela 28 - Impacto das desonerações controlando por intensidade do uso de mão-de-obra

\begin{tabular}{|c|c|c|c|c|c|c|}
\hline \multirow[b]{3}{*}{ Variável } & 1 & 2 & 3 & 4 & 5 & 6 \\
\hline & \multicolumn{3}{|c|}{ Exportação } & \multicolumn{3}{|c|}{ Importação } \\
\hline & quantidade & valor & peso & quantidade & valor & peso \\
\hline produto desonerado & 0,04 & $2,07 * * *$ & -3711 & 0,18 & $-0,06$ & $-594 * *$ \\
\hline tgpgt & $-0,14$ & $-15,23 * * *$ & -5164 & $-1,76$ & $-0,65$ & -345 \\
\hline efeito fixo para NCM & sim & $\operatorname{sim}$ & $\operatorname{sim}$ & sim & $\operatorname{sim}$ & $\operatorname{sim}$ \\
\hline dummy mês & $\operatorname{sim}$ & $\operatorname{sim}$ & sim & $\operatorname{sim}$ & $\operatorname{sim}$ & $\operatorname{sim}$ \\
\hline dummy ano & sim & $\operatorname{sim}$ & sim & $\operatorname{sim}$ & $\operatorname{sim}$ & $\operatorname{sim}$ \\
\hline dummy interação mês e ano & $\operatorname{sim}$ & sim & sim & sim & $\operatorname{sim}$ & $\operatorname{sim}$ \\
\hline _cons & 0,11 & $4,84 * * *$ & $21723 * * *$ & $1,16^{* * *}$ & $2,25 * * *$ & $2659 * * *$ \\
\hline no de observações & 382111 & 382111 & 382111 & 497993 & 497993 & 497993 \\
\hline $\mathrm{R}^{2}$ & 0,001 & 0,003 & 0,001 & 0,001 & 0,006 & 0,002 \\
\hline no de NCM & 4994 & 4994 & 4994 & 5301 & 5301 & 5301 \\
\hline
\end{tabular}

* signficante a $10 \%{ }^{* *}$ significante a $5 \%$ e ${ }^{* * *}$ significante a $1 \%$

Quantidade e valor expressos em milhões, e peso em toneladas

Fonte: Autoria própria

\subsubsection{Estimações utilizando outras variáveis de intensidade do fator trabalho}

Nesta seção testamos se os resultados encontrados na última subseção apresentam alterações relevantes quando utilizamos outras variáveis para capturar a intensidade do fator 
trabalho na produção do bem em substituição à variável gpgt, que é a razão entre o gasto com pessoal e o gasto total na produção do bem.

As alternativas que utilizamos foram gprec, o gasto com pessoal sobre o total das receitas, e o gpva, gasto com pessoal sobre o valor adicionado. Grosso modo, os resultados pouco se alteram quando comparados com os resultados obtidos utilizando o gpgt.

Com relação às exportações, conforme pode ser visto na Tabela 29, apenas o valor FOB utilizando a variável de intensidade de fator trabalho gprec que aponta para um efeito estatisticamente significante das desonerações (coluna 4). E em linha com o resultado encontrado utilizando o gpgt, o efeito é negativo, ou seja, o valor FOB das exportações dos produtos desonerados sofre uma queda em comparação com os produtos não desonerados.

Tabela 29 - Impacto das desonerações sobre exportações com outras variáveis de fator trabalho

\begin{tabular}{|c|c|c|c|c|c|c|}
\hline Variável & $\begin{array}{c}1 \\
\text { quantidade } \\
\end{array}$ & $\begin{array}{c}2 \\
\text { quantidade }\end{array}$ & $\begin{array}{c}3 \\
\text { valor } \\
\end{array}$ & $\begin{array}{c}4 \\
\text { valor } \\
\end{array}$ & $\begin{array}{c}5 \\
\text { peso } \\
\end{array}$ & $\begin{array}{c}6 \\
\text { peso } \\
\end{array}$ \\
\hline produto desonerado & $-0,09$ & 0,04 & $-0,27$ & $-2,46 * * *$ & -886 & -3275 \\
\hline tgpva & 0,15 & - & $-1,50$ & - & -5142 & - \\
\hline tgprec & - & $-0,14$ & - & $-18,28 * * *$ & - & -7671 \\
\hline efeito fixo para NCM & $\operatorname{sim}$ & $\operatorname{sim}$ & $\operatorname{sim}$ & $\operatorname{sim}$ & $\operatorname{sim}$ & $\operatorname{sim}$ \\
\hline dummy mês & $\operatorname{sim}$ & $\operatorname{sim}$ & $\operatorname{sim}$ & $\operatorname{sim}$ & $\operatorname{sim}$ & $\operatorname{sim}$ \\
\hline dummy ano & $\operatorname{sim}$ & $\operatorname{sim}$ & $\operatorname{sim}$ & $\operatorname{sim}$ & $\operatorname{sim}$ & $\operatorname{sim}$ \\
\hline dummy interação mês e ano & $\operatorname{sim}$ & $\operatorname{sim}$ & $\operatorname{sim}$ & $\operatorname{sim}$ & $\operatorname{sim}$ & $\operatorname{sim}$ \\
\hline cons & 0,11 & 0,11 & $4,83 * * *$ & $4,83 * * *$ & $21717^{* * *}$ & $21720 * * *$ \\
\hline no de observações & 382111 & 382111 & 382111 & 382111 & 382111 & 382111 \\
\hline $\mathrm{R}^{2}$ & 0,001 & 0,001 & 0,003 & 0,003 & 0,001 & 0,001 \\
\hline no de NCM & 4994 & 4994 & 4994 & 4994 & 4994 & 4994 \\
\hline
\end{tabular}

* signficante a $10 \%, * *$ significante a $5 \%$ e $* * *$ significante a $1 \%$

Quantidade e valor expressos em milhões, e peso em toneladas

Fonte: Autoria própria

No caso das importações, de acordo com a Tabela 30, encontramos um efeito estatisticamente significante das desonerações sobre o peso líquido das importações utilizando a variável gprec (coluna 6). Este resultado também aponta para uma queda do peso líquido das importações dos bens cujos equivalentes sofreram desoneração no Brasil. Este resultado segue em linha com o resultado encontrado utilizando-se a variável gpgt.

Além disso, utilizando-se a variável gpva, também encontramos um resultado estatisticamente significante (embora apenas a 10\% de nível de significância) sobre o valor FOB das importações (coluna 3). Sendo que quanto maior a intensidade do fator trabalho na produção do bem cujo equivalente foi desonerado no Brasil, menor é o valor FOB deste bem que é importado. 
Tabela 30 - Impacto das desonerações sobre importações com outras variáveis de fator trabalho

\begin{tabular}{|c|c|c|c|c|c|c|}
\hline Variável & $\begin{array}{c}1 \\
\text { quantidade } \\
\end{array}$ & $\begin{array}{c}2 \\
\text { quantidade }\end{array}$ & $\begin{array}{c}3 \\
\text { valor } \\
\end{array}$ & $\begin{array}{c}4 \\
\text { valor } \\
\end{array}$ & $\begin{array}{c}5 \\
\text { peso } \\
\end{array}$ & $\begin{array}{c}6 \\
\text { peso } \\
\end{array}$ \\
\hline produto desonerado & 0,14 & 0,26 & 0,48 & 0,05 & -503 & $-601 * *$ \\
\hline tgpva & $-0,50$ & - & $-0,98 *$ & - & -240 & - \\
\hline tgprec & - & $-2,28$ & - & $-1,26$ & - & -336 \\
\hline efeito fixo para NCM & $\operatorname{sim}$ & $\operatorname{sim}$ & $\operatorname{sim}$ & $\operatorname{sim}$ & $\operatorname{sim}$ & $\operatorname{sim}$ \\
\hline dummy mês & $\operatorname{sim}$ & $\operatorname{sim}$ & $\operatorname{sim}$ & $\operatorname{sim}$ & $\operatorname{sim}$ & $\operatorname{sim}$ \\
\hline dummy ano & $\operatorname{sim}$ & $\operatorname{sim}$ & sim & sim & $\operatorname{sim}$ & $\operatorname{sim}$ \\
\hline dummy interação mês e ano & $\operatorname{sim}$ & $\operatorname{sim}$ & $\operatorname{sim}$ & $\operatorname{sim}$ & $\operatorname{sim}$ & $\operatorname{sim}$ \\
\hline cons & $1,16^{* * *}$ & $1,16^{* * *}$ & $2,25 * * *$ & $2,25 * * *$ & $2659 * * *$ & $2659 * * *$ \\
\hline $\mathrm{n}$ o de observações & 497993 & 497993 & 497993 & 497993 & 497993 & 497993 \\
\hline $\mathrm{R}^{2}$ & 0,001 & 0,001 & 0,006 & 0,006 & 0,002 & 0,002 \\
\hline $\mathrm{n} \cong \mathrm{de}$ NCM & 5301 & 5301 & 5301 & 5301 & 5301 & 5301 \\
\hline
\end{tabular}

* signficante a $10 \%{ }^{* *}$ significante a $5 \%$ e ${ }^{* * *}$ significante a $1 \%$

Quantidade e valor expressos em milhões, e peso em toneladas

Fonte: Autoria própria

\subsubsection{Estimações separando as desonerações em momentos distintos}

Conforme explicamos anteriormente, a desoneração da folha teve como contrapartida a tributação da receita da empresa, contudo a alíquota foi alterada ao longo do tempo. De dezembro de 2011 a julho de 2012, a alíquota era de 1,5\% da receita, e de agosto de 2012 a $31 / 12 / 2014$ passou a ser de $1,0 \%$.

A fim de estimar se esta mudança de alíquota afetou o impacto da desoneração sobre as exportações e importações brasileiras, regredimos também o mesmo modelo econométrico citado na seção de Metodologia, porém separando a variável de tratamento em outras três diferentes variáveis dummies. Embora as três sejam definidas como sendo iguais a 1 para os produtos (códigos NCM) desonerados e zero, caso contrário, elas diferem em relação à extensão no tempo.

Retomando, a primeira variável que chamamos $T_{1}$, que se refere a desoneração no período que a alíquota de tributação da receita foi de $1,5 \%$, é uma dummy igual a 1 para 86 produtos de dezembro de 2011 a março de 2012 e igual a 1 para 401 produtos de abril de 2012 a julho de 2012. A partir de agosto de 2012, a alíquota do imposto compensatório sobre a receita passou para $1,0 \%$, neste sentido, a segunda variável que chamamos $T_{2}$ é uma dummy igual a 1 para os mesmos 401 produtos desonerados em $T_{1}$, porém no período que se estende de agosto de 2012 a 31/12/2014 e, a terceira variável que chamamos $T_{3}$ é uma dummy igual a 1 para os produtos que foram desonerados de agosto de 2012 a 31/12/2014, mas que são diferentes dos 401 produtos já abordados por $T_{2}$. 
De acordo com a Tabela 31, com estas adaptações ao modelo econométrico, encontramos que as desonerações continuam a impactar, na média, de maneira negativa as exportações em valor FOB, e a não ter impacto estatisticamente significante sobre as exportações em quantidade estatística e em peso líquido, assim como no modelo da subseção 3.7.2. Além disso, em linha com o resultado da subseção 3.7.2, quanto mais um bem desonerado for mão-de-obra intensivo, menor será o valor exportado. Porém, de acordo com a Tabela 31, conseguimos identificar que este efeito foi registrado no período em que a alíquota sobre receita vigente foi de $1,0 \%$, ou seja, a partir de agosto de 2012.

Vale notar que a variável $T_{2}$ foi estatisticamente significante a $10 \%$, em relação à variável exportação em quantidade e, segundo este resultado, as exportações dos produtos desonerados tiveram um aumento de mais de 782 mil unidades na unidade estatística correspondente a cada produto.

Com relação às importações, em linha com os resultados da subseção 3.7.2, não encontramos efeito estatisticamente significante sobre as importações em valor FOB e, encontramos um efeito estatisticamente significante e que mostra uma queda das importações em peso líquido dos bens cujos equivalentes foram desonerados internamente. Além disso, assim como nos resultados da seção 3.7.2, a intensidade do uso do fator trabalho na produção dos bens desonerados não altera o efeito das desonerações nas importações. Todavia, identificamos que este impacto significante foi registrado a partir de agosto de 2012 e é oriundo dos produtos que passaram a ser desonerados a partir deste período.

Por outro lado, dissociando do resultado da subseção 3.7.2, encontramos efeitos estatisticamente significante das desonerações sobre a cesta dos 401 produtos que foram desonerados antes mesmo de agosto de 2012. Conforme aponta a Tabela 31, o efeito combinado médio é de queda das importações destes bens e, além disso, quanto mais mão-deobra intensivo for o bem, maior será a queda de sua importação. 
Tabela 31 - Impacto das desonerações em momentos distintos

\begin{tabular}{|c|c|c|c|c|c|c|}
\hline \multirow[b]{3}{*}{ Variável } & 1 & 2 & 3 & 4 & 5 & 6 \\
\hline & \multicolumn{3}{|c|}{ Exportação } & \multicolumn{3}{|c|}{ Importação } \\
\hline & quantidade & valor & peso & quantidade & valor & peso \\
\hline$\overline{T 1}$ & 0,67 & 1,06 & -2621 & $7,06 * *$ & 0,12 & -59 \\
\hline $\mathrm{T} 2$ & $0,78 *$ & $0,69 * * *$ & -4274 & $8,83^{* * *}$ & $-0,25$ & -635 \\
\hline T3 & 0,03 & $2,17^{* * *}$ & -3218 & 0,13 & $-0,06$ & $-667^{* *}$ \\
\hline T1gpgt & $-2,14$ & $-10,19$ & 694 & $-11,45^{* *}$ & $-1,34$ & -676 \\
\hline T2gpgt & $-2,65$ & $-31,53 * * *$ & -3722 & $-31,16^{* * *}$ & 0,01 & -589 \\
\hline T3gpgt & $-0,14$ & $-16,37 * * *$ & -8370 & $-2,16$ & $-0,67$ & 6 \\
\hline efeito fixo para NCM & $\operatorname{sim}$ & $\operatorname{sim}$ & $\operatorname{sim}$ & $\operatorname{sim}$ & $\operatorname{sim}$ & $\operatorname{sim}$ \\
\hline dummy mês & $\operatorname{sim}$ & $\operatorname{sim}$ & $\operatorname{sim}$ & $\operatorname{sim}$ & $\operatorname{sim}$ & $\operatorname{sim}$ \\
\hline dummy ano & $\operatorname{sim}$ & $\operatorname{sim}$ & $\operatorname{sim}$ & $\operatorname{sim}$ & $\operatorname{sim}$ & $\operatorname{sim}$ \\
\hline dummy interação mês e ano & $\operatorname{sim}$ & $\operatorname{sim}$ & $\operatorname{sim}$ & $\operatorname{sim}$ & $\operatorname{sim}$ & $\operatorname{sim}$ \\
\hline cons & 0,12 & $4,84 * * *$ & $21791 * * *$ & $1,17^{* * *}$ & $2,25 * * *$ & $2667 * * *$ \\
\hline no de observações & 382111 & 382111 & 382111 & 497993 & 497993 & 497993 \\
\hline $\mathrm{R}^{2}$ & 0,001 & 0,003 & 0,003 & 0,001 & 0,006 & 0,002 \\
\hline $\mathrm{n} \cong$ de NCM & 4994 & 4994 & 4994 & 5301 & 5301 & 5301 \\
\hline
\end{tabular}

* signficante a $10 \%{ }^{* *}$ significante a $5 \%$ e ${ }^{* * *}$ significante a $1 \%$

Quantidade e valor expressos em milhões, e peso em toneladas

Fonte: Autoria própria

\subsection{CONCLUSÃO}

A desoneração da folha de pagamentos sempre foi um pleito dos industriais brasileiros como uma forma de diminuir o chamado Custo Brasil e, assim, aumentar a competitividade dos bens produzidos em território nacional. Soma-se a isto, o fato do governo, desde os anos noventa, ver na desoneração da folha uma possibilidade de aumentar a formalização da mãode-obra e, consequentemente, mitigar o problema do déficit da Previdência Social.

Foi na gestão de Dilma Roussef, em dezembro de 2011, que o governo substitui a contribuição patronal de $20 \%$ sobre a folha de pagamento pelo imposto igual a uma porcentagem sobre o faturamento bruto anual para um pequeno grupo de atividades. Ficou a cargo do Tesouro Nacional a responsabilidade por compensar possíveis perdas de arrecadação da Previdência. O governo visava com a medida melhorar a competitividade dos setores intensivos em mão-de-obra, fomentar os investimentos e o comércio exterior, criar empregos e aumentar a formalização.

Neste contexto, o presente ensaio visou avaliar o efeito da desoneração da folha de pagamentos sobre o comércio exterior brasileiro. Através de um painel de efeito fixo para produto conforme seu código NCM, estimamos se a desoneração da folha de pagamentos aumentou a competitividade internacional brasileira, ou seja, se aumentou as exportações e/ou reduziu as importações. Utilizamos para isso os dados compilados pelo Ministério da Indústria, Comércio Exterior e Serviços (MDIC) de exportação e importação brasileiros em 
valor FOB, em peso $(\mathrm{Kg})$ e em quantidade (unidade estatística da mercadoria) de janeiro de 2003 até dezembro de 2014. Para capturar a intensidade do uso de mão-de-obra na função de produção de cada bem, criamos alguns indicadores utilizando dados da PIA do IBGE de 2007, são estes: a razão do gasto com pessoal sobre o gasto total; a razão do gasto com pessoal sobre a receita total e a razão do gasto com pessoal sobre o valor adicionado. A variável produto desonerado foi tratada como uma dummy que apresenta valor igual a 1 desde quando o produto, ou seja, o código NCM é desonerado até 31/12/2014, e zero, caso contrário. Utilizamos também algumas variações para a variável tratamento de acordo com a cesta de produtos desonerados e a alíquota do imposto sobre receitas. Vale notar que também utilizamos controles para anos, meses e interação entre meses e anos.

Encontramos que as desonerações impactaram negativamente e de maneira estatisticamente significante todos os indicadores de exportação e importação (valor, peso e quantidade), exceto pela quantidade exportada. Portanto, podemos dizer que a desoneração retraiu o comércio internacional brasileiro, efeito contrário ao desejado pelo governo no momento da adoção da política.

Quando restringimos a amostra para apenas produtos que estão presentes na PIA, encontramos que, em suma, as desonerações foram responsáveis por uma diminuição do valor exportado, sendo que quanto mais intensivo em mão-de-obra o bem, maior a queda. Este resultado pode ser reflexo de uma queda de preço não compensada por um aumento da quantidade. Já com relação às importações, encontramos que a desoneração foi responsável por uma queda da quantidade importada dos bens que tiveram seus similares nacionais desonerados internamente. Tais resultados pouco se alteram quando utilizamos as variáveis alternativas para identificar a intensidade do fator trabalho na produção ou para identificar momentos distintos da desoneração no tempo, sinalizando para a robustez dos nossos resultados.

Isto posto, concluímos que, embora tenha representado um grande esforço fiscal para a União, a desoneração da folha de pagamento não proporcionou um aumento de competitividade internacional ou um fomento do comércio externo a contento. Neste contexto, em meio às renúncias fiscais crescentes $(\mathrm{R} \$ 3,6$ bilhões em 2012, $\mathrm{R} \$ 12,3$ bilhões em 2013 e R\$21,6 bilhões em 2014), em 2015, o governo elevou as alíquotas do imposto compensatório incidente sobre a receita das empresas de $1 \%$ e $2 \%$ para $2,5 \%$ e $4,5 \%$, respectivamente. 


\section{REFERÊNCIAS}

ABDI. Plano Brasil maior. Brasília: 2011. Disponível em: < http://www.abdi.com.br/paginas/pdp.aspx >. Acesso em: 02/04/2017.

Brasil maior - Balanço Executivo - 2 anos. Brasília. 2013. Disponível em: < http://www.abdi.com.br/Estudo/PBM - Balanço_.pdf pdf >. Acesso em: 02/04/2017.

Plano Brasil maior - ABDI 2011-2014. Brasília. 2015. Disponível em: < http://www.abdi.com.br/paginas/pdp.aspx >. Acesso em: 02/04/2017.

ACEMOGLU, Daron; ANTRÀS, Pol; HELPMAN, Elhanan. Contracts and Technology Adoption. American Economic Review, v. 97, n. 3, p. 916-943, 2007.

AFONSO, António; GOMES, Pedro; FURCERI, Davide. Sovereign credit ratings and financial markets linkages: Application to European data. Journal of International Money and Finance, Vol. 31, No. 3, pp. 606-639, 2012.

AFONSO, António; GOMES, Pedro; TAAMOUTI, Abderrahim. Sovereign credit ratings, market volatility, and financial gains. Computational Statistics \& Data Analysis, Vol. 76, pp. 20-33, 2014.

AHN, JaeBin; KHANDELWAL, Amit; WEI, Shang-Jin. The role of intermediaries in facilitating trade. Journal of International Economics, v. 84, n. 1, p.73-85, 2011.

AITKEN, Brian; HANSON, Gordon; HARRISON, Ann. Spillovers, foreign investment, and export behavior. Journal of International Economics, v.43, n. 1-2, p. 103-132, 1997.

ALBORNOZ, Facundo; CORCOS, Gregory; ORNELAS, Emanuel; PARDO, Héctor. Sequential Exporting. Journal of International Economics, v.88, n. 1, p. 17-31, 2012.

ALSAKKA, Rasha; GWILYM, Owain ap. Rating agencies's signals during the European sovereign debt crisis: market impact and spillovers. Journal of Economics Behavior \& Organization, Vol. 85, pp. 144-162, 2013.

AMIN, Mohammad. Labor regulation and employment in India's retail stores. Journal of Comparative Economics, v. 37, n. 1, p. 47-61, 2009.

AMITI, Mary; KHANDELWAL, Amit K. Import competition and quality upgrading. Review of Economics and Statistics, v. 95, n. 2, p. 476-490, 2013.

ANDERSON, James; MARCOUILLER, Douglas. Insecurity and the Pattern of Trade: An Empirical Investigation. Review of Economics and Statistics, v. 84, n. 2, p. 342-352, 2002.

ANDERSON, Ronald W.. Credit default swaps: what are the social benefits and costs? Financial Stability Review, 1-14, 2010.

ANG, James; PATEL, Kiritkumar. Bond Rating Methods: Comparison and Validation. The Journal of Finance, Vol. 30, No. 2, pp. 631-640, 1975. 
ANSILIERO, Graziela et al. A desoneração da folha de pagamentos e sua relação com a formalidade no mercado de trabalho. Texto para Discussão, Instituto de Pesquisa Econômica Aplicada (IPEA), 2008.

ARAUJO, Luis; MION, Giordano; ORNELAS, Emanuel. Institutions and Export Dynamics. Journal of International Economics, v. 98, p. 2-20, 2016.

ARAUJO, Luis; ORNELAS, Emanuel. Trust-based Trade. CEP Discussion Paper No. 820, 2007.

ARKOLAKIS, Costas; GANAPATI, Sharat; MUENDLER, Marc-Andreas. The extensive margin of exporting products: A firm-level analysis. National Bureau of Economic Research, w16641, 2014.

ARKOLAKIS, Costas; MUENDLER, Marc-Andreas; The extensive margin of exporting products: the continuum case. Working, 2011.

ASKER, John; COLLARD-WEXLER, Allan; DE LOECKER, Jan. Dynamic Inputs and Resource (Mis) Allocation. Journal of Political Economy, forthcoming, 2013.

BARRO, Robert; LEE, Jong-Wha. International Data on Education Attainment Updates and Implications. NBER Working Paper, nº 7911, 2000.

BECKER, Sascha; MUENDLER, Marc-Andreas. Trade and tasks: an exploration over three decades in Germany, n. 20739, NBER Working Papers, National Bureau of Economic Research, Inc.

BEIRNE, John; FRATZSCHER, Marcel. The pricing of sovereign risk and contagion during the European sovereign debt crisis. Journal of International Money and Finance, Vol. 34, pp. 60-82, 2013.

BEKAERT, Geert; HARVEY, Campbell R.. Foreign Speculators and Emerging Equity Markets. The Journal of Finance. Vol. LV, No.2, 2000.

BEKAERT, Geert; HARVEY, Campbell R.; LUMSDAINE, Robin. Dating the integration of world capital markets. Working paper. Stanford University and Duke University, 1998.

BERNARD, Andrew; JENSEN, Bradford. Exceptional Exporter Performance: Cause, Effect, or Both? Journal of International Economics, Vol. 47, no. 1, pp. 1-25, 1999.

. Why Some Firms Export? The Review of Economics and Statistics, MIT Press, Vol. 86(2), pp. 561-569, 2004.

BOSCH, Mariano; GOÑI-PACCHIONI, Edwin; MALONEY, William. Trade liberalization, labor reforms and formal-informal employment dynamics. Labor Economics, v. 19, n. 5, p. 653-667, 2012.

BOSWORTH, Barry; COLLINS, Susan; REINHART, Carmen. Capital Flows to Developing Economies: Implications for Saving and Investment. Brookings Papers on Economics Activit., Vol. 1999, No. 1, pp. 143-180, 2009. 
BRAMBILLA, Irene; DIX-CARNEIRO, Rafael; LEDERMAN, Daniel; PORTO, Guido. Skills, exports, and the wages of seven million Latin American workers. World Bank Economic Review, v. 26, n. 1, p. 34-60, 2011.

BRASIL. Lei $\mathrm{n}^{\circ}$ 12.546, de 14 de dezembro de 2011. 2011a. Diário Oficial da República Federativa do Brasil. Brasília, 14 de dezembro de 2011. Disponível em: < http://www.planalto.gov.br/ccivil_03/_ato2011-2014/2011/lei/112546.htm >. Acesso em: 02/04/2017.

Lei $\mathrm{n}^{\circ}$ 12.715, de 17 de setembro de 2012. Altera a alíquota das contribuições previdenciárias sobre a folha de salários devidas pelas empresas que especifica e dá outras providências. Diário Oficial da República Federativa do Brasil. Brasília, 17 de setembro de 2012. Disponível em: < http://www.planalto.gov.br/ccivil_03/_ato20112014/2012/lei/l12715.htm >. Acesso em: 02/04/2017.

Lei $\mathrm{n}^{\circ} 12.794$, de 2 de abril de 2013. Altera a Lei $\mathrm{n}^{\circ} 12.546$, de 14 de dezembro de 2011, quanto à contribuição previdenciária de empresas dos setores industriais e de serviços e dá outras providências. Diário Oficial da República Federativa do Brasil. Brasília, 2 de abril de 2013. Disponível em: < http://www.planalto.gov.br/ccivil_03/_ato20112014/2013/lei/l12794.htm >. Acesso em: 02/04/2017.

Lei $\mathrm{n}^{\mathrm{o}} 12.844$, de 19 de julho de 2013. Altera o regime de desoneração da folha de pagamentos e dá outras providências. Diário Oficial da República Federativa do Brasil. Brasília, 19 de julho de 2013. Disponível em: < http://www.planalto.gov.br/ccivil_03/_ato2011-2014/2013/lei/112844.htm >. Acesso em: 02/04/2017.

Lei $\mathrm{n}^{\circ}$ 13.161, de 31 de agosto de 2015. Altera as Leis nos 12.546, de 14 de dezembro de 2011, quanto à contribuição previdenciária sobre a receita bruta e dá outras providências. Diário Oficial da República Federativa do Brasil. Brasília, 31 de agosto de 2015. Disponível em: < http://www.planalto.gov.br/ccivil_03/_ato20152018/2015/lei/L13161.htm>. Acesso em: 02/04/2017.

Ministério da Fazenda. Cartilha de desoneração do Ministério da Fazenda. Brasília:
2012.
Disponível http://www.fazenda.gov.br/noticias/2012/abril/CartilhaDesoneracao.pdf/view> . Acesso em: 02/04/2017.

. Medida Provisória, nº 540, de 2 de agosto de 2011. 2011b. Institui o Regime Especial de Reintegração de Valores Tributários para as Empresas Exportadoras e dá outras providências. Diário Oficial da República Federativa do Brasil. Brasília, 3 de agosto de 2011. Disponível em: < http://www.planalto.gov.br/ccivil_03/_ato20112014/2011/mpv/540.htm>. Acesso em: 02/04/2017.

Medida Provisória, no 563, de 3 de abril de 2012. 2012a. Altera a alíquota das contribuições previdenciárias sobre a folha de salários e dá outras providências. Diário Oficial da República Federativa do Brasil, Poder Executivo, Brasília, DF 3 de abril de 2012. Disponível em: < http://www.planalto.gov.br/ccivil_03/_ato20112014/2012/mpv/563.htm >. Acesso em: 02/04/2017. 
Medida Provisória, $\mathrm{n}^{\circ}$ 582, de 20 de setembro de 2012. Altera a Lei $\mathrm{n}^{\circ} 12.546$, de 14 de dezembro de 2011, quanto à contribuição previdenciária de empresas dos setores industriais e de serviços e dá outras providências. Diário Oficial da República Federativa do Brasil, Poder Executivo, Brasília, DF 20 de setembro de 2012. Disponível em: < http://www.planalto.gov.br/ccivil_03/_ato2011-2014/2012/Mpv/582.htm >. Acesso em: 02/04/2017.

Medida Provisória, $\mathrm{n}^{\circ}$ 610, de 2 de abril de 2013. Diário Oficial da República Federativa do Brasil, Poder Executivo, Brasília, DF 2 de abril de 2013. Disponível em: < http://www.planalto.gov.br/ccivil_03/_ato2011-2014/2013/Mpv/mpv610.htm >. Acesso em: 02/04/2017.

Receita Federal. Desoneração da Folha de Pagamento - Estimativa de Renúncia e Metodologia de Cálculo. 2015. Brasília. Disponível em: < https://www.receita.fazenda.gov.br/publico/arre/RenunciaFiscal/Desoneracaodafolha.pdf $>$.

Acesso em: 02/04/2017.

BRENNAN, Michael; CAO, Henry. International Portfolio Investment Flows. The Journal of Finance. Vol. LII, No. 5, 1997.

BROOKS, Raymond; PATEL, Ajay; SU, Tie. How the Equity Market Responds to Unanticipated Events. The Journal of Business. Vol. 76, No. 1, pp. 109-133, 2003.

BROOKSA, Robert; FAFF, Robert W.; HILLIERC, David; HILLIERD, Joseph. The National Market Impact of Sovereign Rating Changes. Journal of Banking \& Finance. Vol.28, Issue 1, pp.233-250, 2004.

BROWN, Stephen; WARNER, Jerold. Measuring Security Price Performance. Journal of Financial. Economics. pp. 205-258, 1980.

Using Daily Stock Returns: The Case of Event Studies. Journal of Financial Economics. Vol. 14, pp.3-31, 1985.

BUGAMELLI, Matteo; INFANTE, Luigi. Sunk costs of exports: a role for industrial districts?. Banca d'Italia, Local Economies and Internationalization in Italy, Roma: Banca d'Italia, p. 343-372, 2005.

CAMPBELL, John; TAKSLER, Glen. Equity Volatility and Corporate Bond Yield. The Journal of Finance. Vol. 58, No. 6, pp. 2321-2349, 2003.

CANTOR, Richard; PACKER, Frank. Determinants and Impact of Sovereign Credit Ratings. Federal Reserve Bank of New York Review. 1996.

CHAN, Kalok; COVRIG, Vicentiu; NG, Lilian. What Determines the Domestic Bias and Foreign Bias? Evidence from Mutual Fund Equity Allocations Worldwide. The Journal of Finance. Vol.LX, No. 3, 2005.

CHARI, Anusha; HENRY, Peter. Risk Sharing and Asset Prices: Evidence from a Natural Experiment. The Journal of Finance. Vol.LIX, No. 3, 2004.

CHRISTOPHER, Raquel; KIM, Suk-Joong; WU, Elisa. Do sovereign credit ratings influence regional stock and bond market interdependencies in emerging countries? Journal of 
International Financial Markets, Institutions and Money. Vol. 22, No. 4, pp. 1070-1089, 2012.

CLARKE, George; CULL, Robert; KISUNKO, Gregory. External finance and firm survival in the aftermath of the crisis: Evidence from Eastern Europe and Central Asia. Journal of Comparative Economics, v. 40, n. 3, p. 372-392, 2012.

CLERIDES, Sofronis; LACH, Saul; TYBOUT, James. Is "learning-by-exporting" Important? Micro-dynamic evidence from Colombia, Mexico and Morocco. The Quarterly Journal of Economics, Vol. 113, No. 3, pp. 903-947, 1998.

COSTINOT, Arnaud. On the Origins of Comparative Advantage. Journal of International Economics, v. 77, p. 255-264, 2009.

CUÑAT, Alejandro; MELITZ, Marc J. A many-country, many-good model of labor market rigidities as a source of comparative advantage. Journal of the European Economic Association, v. 8, n. 2-3, p. 434-441, 2010.

Volatility, labor Market flexibility, and the pattern of comparative advantage. Journal of the European Economic Association, v. 10, n. 2, p.225-254, 2012.

DAS, Sanghamitra; ROBERTS, Mark J.; TYBOUT, James R. Market entry costs, producer heterogeneity, and export dynamics. Econometrica, v. 75, n. 3, p. 837-873, 2007.

DATZ, Giselle. Reframing Development and Accountability: The Influence of Sovereign Credit Ratings on Policy Making in Developing Countries. Third World Quarterly. Vol. 25, No. 2, pp. 303-318, 2004.

DAVIS, Donald R. Does European Unemployment prop up American Wages? The American Economic Review, vol. 88, n. 3, p. 478-494, 1998.

DE BARROS, Ricardo Paes; CORSEUIL, Carlos Henrique. The impact of regulations on Brazilian labor Market performance. Law and Employment: Lessons from Latin America and Caribean, National Bureau of Economic Research, p. 273-350, 2004.

DICHEV, Ilia; PIOTROSKI, Joseph. The Long Run Stock Returns following Bond Ratings Changes. The Journal of Finance. Vol. 56, No. 1, pp. 173-203, 2001.

DIX-CARNEIRO, Rafael. Trade liberalization and labor market dynamics. Econometrica, vol. 82, n. 3, p.825-885, 2014.

DIX-CARNEIRO, Rafael; KOVAK, Brian K. Trade liberalization and the skill premium: a local labor markets approach. National Bureau of Economic Research, w20912, 2015.

DIXIT, Avinash. Entry and exit decisions under uncertainty. Journal of Political Economy, p. 620-638, 1989.

DJANKOV, Simeon; RAMALHO, Rita. Employment laws in developing countries. Journal of Comparative Economics, v. 37, n. 1, p. 3-13, 2009.

DO, Quy-Toan; LEVCHENKO, Andre A. Trade, Inequality and the Political Economy of Institutions. Journal of Economic Theory, v. 144, p. 1489-1520, 2009. 
DOMINGUES, Edson Paulo et al. Crescimento, emprego e produção setorial: efeitos da desoneração de tributos sobre a folha de salários no Brasil. Cedeplar, Universidade Federal de Minas Gerais, 2012.

DURBIN, Erik; NG, David. The sovereign ceiling and emerging market corporate bond spreads. Journal of International Money and Finance. 2004.

EATON, Jonathan; KORTUM, Samuel. Technology, Geography, and Trade. Econometrica, v. 70, n. 5, p. 1741-1779, 2002.

EDERINGTON, Louis; GOH, Jeremy. Bond Rating Agencies and Stock Analysts: Who Knows What When? Journal of Financial and Quantitative Analysis. Vol. 33, No. 4, 1998.

EDERINGTON, Louis; GOH, Jeremy. Is a Bond Rating Downgrade Bad News, Good News, or No News for Stockholders. Journal of Finance. Vol. XLVIII, No. 5, 1993.

EICHER, Theo; KANG, Jong Woo. Trade, foreign direct investment or acquisition: Optimal entry modes for multinationals. Journal of Development Economics, v. 77, n. 1, p. 207-228, 2005.

FAKIH, Ali; GHAZALIAN, Pascal. Why Some Firms Export? An Empirical Analysis for Manufacturing Firms in the MENA Region. IZA Discussion Paper Series, $n^{\circ}$ 7172, 2013.

FEENSTRA, Robert; INKLAAR, Robert; TIMMER, Marcel. The Next Generation of Penn World Trade. Forthcoming in American Economic Review, 2015.

FEENSTRA, Robert; LIPSEY, Robert; DENG, Haizan; MA, Alyson; MO, Hengyong. World Trade Flows. NBER Working Paper, nº 11040, 2005.

FERNANDES,R.; MENEZES FILHO, Naércio. O mercado de trabalho no Brasil: políticas, resultados e desafios. In: CHAHAD, J. P. Z.; FERNANDES, R. (Orgs.). Impactos dos encargos trabalhistas sobre o setor informal da economia. 1ª. Ed. São Paulo: [s. n.], 2002. V. 1, p. 149-175.

FERREIRA, Miguel; GAMA, Paulo. Does sovereign debt ratings news spill over to international stock market? Journal of Banking and Finance. Vol. 31, No. 10, pp. 31623182, 2007.

FISCHER, Stanley. Capital Account Liberalization and the Role of the IMF. In "Should the IMF Pursue Capital-Account Convertibility?" Essays in International Finance 207. Princeton, NJ: Princeton University, 1-10, 1998.

FORTE, Santiago; PEÑA, Juan Ignacio. Credit spreads: an Empirical analysis on the informational content of stocks, bonds and CDS. Journal of Banking and Finance. Vol. 33, No. 11, pp. 2013-2025, 2009.

FREUND, Carolina; PIEROLA, Martha. Export Entrepreneurs: Evidence from Peru. World Bank Policy Research. Working Paper 5407, 2010.

FROOT, Kenneth; O'CONNELL, Paul; SEASHOLES, Mark. The Portfolio Flows of International Investors. Journal of Financial economics. Vol. 59, pp.151-193, 2000. 
GANDE, Amar; PARSLEY, David. News spillovers in the sovereign debt market. Journal of Financial economics. Vol. 75, No. 3, pp.691-734, 2005.

Sovereign credit ratings, transparency and international portfolio flows. 2014.

GHIRONI, Fabio; MELITZ, Marc. Trade Flow Dynamics with Heterogeneous Firms. American Economic Review P\&P 97: 356-361, 2007.

GOH, Jeremy; EDERINGTON, Louis. Is a Bond Rating Downgrade Bad News, Good News, or No News for Stockholders. The Journal of Finance. Vol. 48, No. 5, pp. 2001-2008, 1993.

GONZAGA, Gustavo; MENEZES FILHO, Naércio; CAMARGO, J. M.. Os efeitos da redução da jornada de trabalho de 48 para 44 horas semanais em 1988. Revista Brasileira de Economia, Rio de Janeiro, v. 57, n. 3, 2003.

GONZAGA, Gustavo; MENEZES FILHO, Naércio; TERRA, Maria Cristina. Trade Liberalization and the Evolution of Skill Earnings Differentials in Brazil. Journal of International Economics, v. 68, n. 2, p. 345-367, 2006.

GREIF, Avner. Contract Enforceability and Economic Institutions in Early Trade: the Maghribi Traders' Coalition. The American Economic Review, v. 83, n. 3, p. 525-548, 1993.

GRIFFIN, Paul; SANVICENTE, Antonio. Common stock returns and rating changes: A methodological comparison. Journal of Finance. Vol. 37, pp. 103-119, 1982.

GUERCIO, Diane Del; TKAC, Paula. The Determinants of the Flow of Funds of Managed Portfolios: Mutual Funds vs. Pension Funds. Journal of Financial and Quantitative Analysis. Vol. 37, No 4, 2002.

HALVORSEN,Robert; PALMQUIST, Raymond. The Interpretation of Dummy Variables in Semilogarithmic Equations. American Economic Review, v. 70, n. 3, p. 474-475, 1980.

HAND, John; HOLTHAUSEN, Robert; LEFTWICH, Richard. The Effect of Bond Rating Agency Announcements on bond and stock prices. Journal of Finance. Vol. 47, pp 733-752, 1992.

HECKMAN, James; PAGÉS-SERRA, Carmen. The Cost of Job Regulation: Evidence from Latin American Labor Markets. National Bureau of Economic Research, 853, $\mathrm{n}^{\mathbf{0}}$ w7773, 2000 .

HELPMAN, Elhanan; ITSKHOKI, Oleg. Labour market rigidities, trade and unemployment. The Review of Economic Studies, v. 77, n. 3, p. 1100-1137, 2010.

HOLTHAUSEN, Robert; LEFTWICH, Richard. The effect of bond rating changes on common stock prices. Journal of Financial Economics. Vol. 17, pp. 57-90, 1986.

HULL, John; PREDESCU, Mirela; WHITE, Alan. The relationship between credit default swap spreads, bond yields and credit rating announcements. Journal of Banking and Finance. Vol. 28, No. 11, pp. 2789-2811, 2004. 
ISMAILESCU, Iuliana; KAZEMI, Hossein. The reaction of emerging market credit default swap spreads to sovereign credit rating changes. Journal of Banking and Finance. Vol. 34, No. 12, pp. 2861-2873, 2010.

ISRAEL, Ronen; OFER, Aharon; SIEGEL, Daniel. The Use of Changes in Equity Value as a Measure of the Information Content of Announcements of Changes in Financial Policy. Journal of Business \& Economics Statistics. Vol. 8, No. 2, pp. 209-216, 1990.

JORION, Philippe; ZHANG, Gaiyan. Credit contagion from counterparty risk. Journal of Finance. Vol. 64, No. 5, pp. 2053-2087, 2009.

Good and bad credit contagion: Evidence from credit default swaps. Journal of Financial Economics. Vol. 84, No. 3, pp. 860-883, 2007.

KADIYALA, Rao; LOCKWOOD, Larry. Risk Measurement for Event-Dependent Security Returns. Journal of Business \& Economics Statistics. Vol. 6, No. 1, pp. 43-49, 1988.

KAMINSKY, Graciela; SCHMUKLER, Sergio. Emerging Market Instability: Do Sovereign Ratings Affect Country Risk and Stock Returns? World Bank Economic Review. Vol. 16, pp. $171-195,2002$.

KATZ, Steven. The Price Adjustment Process of Bonds to Rating Reclassifications: A Test of Bond Market Efficiency. Journal of Finance. Vol.29, pp. 551-59, 1974.

KHOTARI, S.; WARNER, Jerold. Econometrics of Event Studies, Forthcoming in B. Espen Eckbo (ed.). Handbook of Corporate Finance: Empirical Corporate Finance. Vol. A, Ch. $1,2006$.

KIM, Han; SINGAL, Vijay. Stock Markets Openings: Experience of Emerging Economies. The Journal of Business. Vol. 73, No. 1,pp. 25-66, 2000.

KING, Michael; SINCLAIR, Timothy. Private Actors and Public Policy: A Requiem for the New Basel Capital. International Political Science Review / Revue internationale de science politique. The Political Economy of International Finance / L'Economie politique de la finance international, Vol. 24, No. 3,pp. 345-362, 2003.

KRUGMAN, P. R.. Scale economies, product differentiation, and the pattern of trade. American Economic Review, Vol. 70, n.5, p. 950-959, 1980.

LAURENT, Pierre; MEUNIER, Nicolas; MIOTTI, Luis; QUENAN, Carlos; SELTZ, Veronique. Emerging Countries's External Debt: How Should One Neutralize Hard-Currency Volatility? Revue Économique. Vol. 54, No. 5, Macroeconomics of Exchange Rate Regimes, pp. 1033-1055, 2003.

LEVCHENKO, Andrei A. Institutional Quality and International Trade. The Review of Economic Studies, v.74, n.3, p.791-819, 2007.

MACKINLAY, Craig. Event Studies in Economics and Finance. Journal of Economic Literature. Vol. 35, No. 1, 1997.

MARTELL, Rodolfo. The Effect of Sovereign Credit Rating Changes on Emerging Stock Markets. Working Paper Purdue University. 2005. 
MARTIN, P.; REY, H.. Financial Globalization and Emerging Markets: With or Without Crash? Working Paper, Federal Reserve Bank of New York and Princeton University, 2002.

MASULIS, Ronald. The Effects of Capital Structure Change on Security Prices A Study of Exchange Offers. Journal of Financial Economics. Vol. 8, pp. 139-178, 1980.

MELITZ, Marc. The impact of trade on intra-industry reallocations and aggregate industry productivity. Econometrica, vol. 71, n. 6, p. 1695-1725, 2003.

MENEZES-FILHO, Naércio; MUENDLER, Marc-Andreas. Labor Reallocation in Response to Trade Reform. NBER Working Paper nº17372, 2011.

NORDEN, Lars; WEBER, Martin. Information efficiency of credit default swap and stock markets: The impact of credit rating announcements. Journal of Banking and Finance. Vol. 28, No. 11, pp. 2813-2843, 2004.

NUNN, Nathan. Relationship-specificity, incomplete contracts, and the pattern of trade. The Quarterly Journal of Economics, vol. 122, n. 2, p. 569-600, 2007.

PAIVA, L. H.; ANSILIERO, G.. A desoneração da contribuição patronal sobre a folha de pagamentos: uma solução à procura de problemas. Planejamento e Políticas Públicas, Brasília, n. 32, p. 9-36, jan-jun, 2009.

PAES DE BARROS, Ricardo; CORSEUIL, Carlos Henrique. The impact of regulations on Brazilian labor Market performance. Law and Employment: Lessons from Latin America and Caribean, National Bureau of Economic Research, p. 273-350, 2004.

PESENDORFER, Martin; SCHMIDT-DENGLER, Philipp. Asymptotic Least Squares Estimators for Dynamic Games. Review of Economic Studies, v. 75, p. 901-928, 2008.

PINCHES, George; SINGLETON, Clay. The Adjustment of Stock Prices to Bond Rating Changes. The Journal of Finance. Vol. XXXIII, No. 1, 1978.

REINHART, Carmen; ROGOFF, Kenneth. The Modern History of Exchange Rate Arrangements: a Reinterpretation. The Quarterly Journal of Economics. Vol. CXIX, issue $1,2004$.

RIBEIRO, J. A. C. et al. Desoneração de folha de pagamentos: breves lembretes e comentários. In: RIBEIRO, A. C.; LUCHEZI, J. A.; MENDONÇA, S. E. A. (Orgs.). Progressividade da tributação e desoneração da folha de pagamentos: elementos para reflexão. Brasília: IPEA; SINDIFISCO; DIEESE, 2011. cap. 6, p. 105-120.

ROBERTS, Mark J.; TYBOUT, James R. The decision to export in Colombia: an empirical model of entry with sunk costs. The American Economic Review, p. 545-564, 1997.

RODRIK, Dani. Who Needs Capital-Account Convertibility? Essays in International Finance 207, Princeton, New Jersey: Princeton University, 1998.

SALINGER, Michael. Value Event Studies. The Review of Economics and Statistics. Vol. 74, No. 4, pp. 671-677, 1992. 
SANTOS-PAULINO, Amelia U. Trade liberalisation and export performance in selected developing countries. Journal of Development Studies, v. 39, n. 1, p. 140-164, 2002.

SCARABEL, Mirela Virginia Perrella. O impacto de mudanças de rating soberano sobre a taxa de câmbio em países emergentes. 2010. Dissertação (Mestrado em Teoria Econômica) - Faculdade de Economia, Administração e Contabilidade, Universidade de São Paulo, São Paulo, 2010. doi:10.11606/D.12.2010.tde-29112010-183257. Acesso em: 2017-04-25.

STIGLITZ, Joseph. Capital Market Liberalization, Economic Growth, and Instability. World Development. 28(6): 1075-86, 2000.

SUMMERS, Lawrence H.. International Financial Crises: Causes, Prevention, and Cures. American Economic Review. Vol. 90, No. 2, pp.1-16, 2000.

TREEPONGKARUNA, Sirimon; WU, Elisa. Realizing the volatility impacts of sovereign credit ratings information on equity and currency markets: Evidence from Asia Financial Crisis. Research in International Business and Finance, Vol. 26, No. 3, pp.335-352, 2012.

ZANGHELINI, N.; BRAGA-JÚNIOR, F. R.; DUARTE, M. M. Desoneração da folha de pagamentos: oportunidades ou ameaça? Brasília: Associação Nacional dos AuditoresFiscais da Receita Federal do Brasil, 2012. 


\begin{abstract}
ANEXO
A.1 Uma breve descrição da metodologia de estudo de evento.

Esta metodologia surgiu com os trabalhos de Brown e Warner (1980, 1985), MacKinlay (1997) e Khotari e Warner (2006). A ideia é diagnosticar se o retorno do ativo no dia do evento é anormal, ou seja, estatisticamente diferente do retorno costumeiro (normal) do ativo. Se assim for, concluímos que o evento tem impacto no retorno do ativo.

Primeiramente, definem-se o ativo e o evento analisados. Conforme ilustrado pela figura da Linha do Tempo abaixo, considera-se o dia do evento como o tempo zero e, consequentemente, o período antes do zero é o período anterior ao evento, enquanto que o período depois do zero é o período posterior ao evento.
\end{abstract}

Figura - Linha do tempo

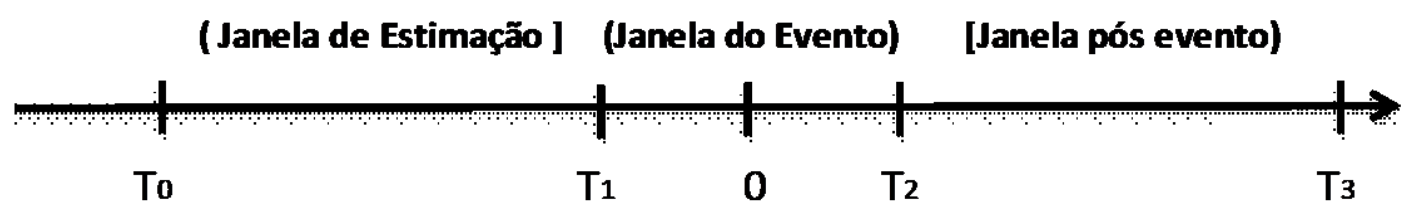

Fonte: Autoria própria

O período anterior ao evento - chamado de janela de estimação - é utilizado para calcular o retorno normal do ativo, ou seja, o retorno do ativo sem a influência do evento. $\mathrm{O}$ retorno anormal é a diferença do retorno do dia do evento menos o retorno normal.

Existem diversas maneiras de calcular o retorno normal. A mais simples delas é considerar o retorno normal constante e calculá-lo como a média aritmética simples dos retornos diários no período anterior ao evento como descrito na equação abaixo.

$$
R n_{i t}=\frac{1}{\left(T_{1}-T_{0}+1\right)} \sum_{t=T_{0}}^{T_{1}} R_{i t}
$$

Em que $R_{i t}$ e $R n_{i t}$ são, respectivamente, o retorno efetivo e o retorno normal do ativo $i$ no tempo $t$. 
O trabalho de Brown e Warner $(1980,1985)$ demonstrou que o retorno normal constante produz resultados muito similares aos dos modelos mais sofisticados ${ }^{32}$. Consequentemente, adotando o retorno normal constante, o retorno anormal é calculado conforme a equação abaixo:

$$
A R_{i 0}=R_{i 0}-\frac{1}{\left(T_{1}-T_{0}+1\right)} \sum_{t=T_{0}}^{T_{1}} R_{i t}
$$

Em que $A R_{i 0}$ é o retorno anormal do ativo $i$ no tempo 0 .

A escolha de $T_{0}$ e $T_{1}$ também fica a critério do pesquisador. A literatura definiu como horizonte longo a distância entre $T_{0}$ e $T_{1}$ maior ou igual a 1 ano; caso contrário o horizonte é considerado curto.

Brown e Warner (1985) mostram que quanto maior for a distância entre $T_{0}$ e $T_{1}$, ou seja, quanto maior for a janela da estimação do retorno normal, mais suscetível a erros estará a estimação. Isto ocorre porque, ao longo do tempo, outros eventos podem modificar estruturalmente o retorno do ativo. Portanto, em um espaço de tempo maior, o retorno normal calculado pode ficar "poluído" com o efeito de outros eventos.

Ao mesmo tempo, uma janela de estimação curtíssima tende a agravar o viés do retorno normal, pois se há outro evento neste período, seu efeito não consegue ser diluído no tempo.

Dada a falta de metodologia para a escolha do tamanho da janela, disseminou-se o uso de janelas de 239 e de 30 dias, ambas considerados como horizontes curtos. Todavia dado a evolução dos mercados financeiros e a adoção de computadores que aumentaram a rapidez do mercado, convencionou-se na literatura mais recente utilizar apenas a janela de 30 dias.

Além de identificar se o evento afeta significativamente o retorno do ativo, a literatura faz uso de tal metodologia para identificar mais dois fatores de interesse: a antecipação do mercado ao anúncio do evento e a existência de efeitos defasados após o anúncio do evento.

\footnotetext{
${ }^{32}$ Dentre uma extensa gama de opções de cálculo do retorno normal, destacam-se: o modelo de mercado o qual relaciona o retorno de uma ação específica ao retorno de um portfólio e o modelo que o retorno normal é calculado utilizando a metodologia do CAPM.
} 
Para verificar se um evento é antecipado ou não, calcula-se o retorno anormal para alguns dias que antecedem o evento. Se estes retornos anormais forem estatisticamente diferentes de zero conclui-se que o evento foi antecipado.

O mesmo procedimento é adotado para verificar a existência de efeitos defasados (timing da resposta do mercado ao anúncio), entretanto os retornos anormais analisados são aqueles posteriores ao dia do evento.

Nomeia-se janela do evento o período que se estende desde o primeiro dia utilizado para captar a antecipação do evento, passando pelo dia do anúncio do evento até o último dia do período considerado para captar os efeitos defasados do mercado. Na figura da Linha do Tempo, podemos identificar a janela do evento entre $T_{1}$ e $T_{2}$. No caso de se adotar a janela do evento como sendo 5 dias anteriores e posteriores ao evento, teremos que $T_{1}=-6$ e $T_{2}=+6$. E o valor de $T_{0}=-36$ quando se utiliza a janela de estimação de 30 dias.

Outro conceito muito disseminado na metodologia de estudo de evento é o retorno anormal acumulado. A possibilidade de haver antecipação do evento e efeitos defasados torna a análise do retorno anormal acumulado mais adequada para diagnosticar o efeito de um evento no retorno de um ativo.

Definimos o retorno anormal acumulado como sendo a soma dos retornos anormais de cada dia que compõem a janela do evento como ilustrado na equação abaixo:

$$
C A R_{i}\left(T_{1}+1, T_{2}-1\right)=\sum_{t=T_{1}+1}^{T_{2}-1} A R_{i t}
$$

Em que $C A R_{i}\left(T_{1}+1, T_{2}-1\right)$ é o retorno anormal acumulado calculado de $T_{1}+1$ a $T_{2}-1$. Usualmente utiliza-se o $\operatorname{CAR}(-5,+5)$ e o $\operatorname{CAR}(0,+1)$ para capturar o efeito do evento no retorno do ativo, bem como o CAR $(-5,-1)$ e o CAR $(+2,+5)$ para identificar a antecipação do mercado e a existência de efeitos defasados, respectivamente.

A exemplo de Gande e Parsley (2005), a literatura que estuda o contágio dos eventos de mudança de ratings trouxe à tona alguns problemas em relação ao cálculo do retorno anormal. Isto porque se o efeito de contágio existe, um evento de mudança de rating em um país $i$ afeta a cotação do ativo de um país $j$, e consequentemente, o cálculo do retorno normal de $j$ (a média do retorno do ativo na janela de 30 dias) estará contaminado pelo evento no país $i$. Este "viés" do cálculo do retorno normal traz problemas tanto para o uso do país $j$ como grupo de "controle" na estimação do painel como no caso em que o país $j$ sofre uma mudança de rating em menos de 30 dias de diferença do evento no país $i$. 
Neste contexto, passou-se a utilizar no lugar do retorno anormal acumulado (CAR), simplesmente o retorno acumulado (CR) em uma janela de estimação bem pequena, no caso de Gande e Parsley (2005) de apenas 2 dias, isto é, o dia do evento e o dia posterior ao dia do evento. Para medir a antecipação do ativo ao evento, passou-se a utilizar o retorno acumulado (CR) em períodos anteriores a data do evento (sem incluir a data do evento).

Tabela A.2 - Resultados do modelo básico (com CAR)

\begin{tabular}{|c|c|c|c|}
\hline & & up & down \\
\hline \multirow{6}{*}{ CDS } & $\operatorname{CAR}(0,+1)$ & $-1,27 \% * *$ & $3,23 \% * * *$ \\
\hline & $\operatorname{CAR}(-5,+5)$ & $-1,39 \%$ & $-1,28 \%$ \\
\hline & $\operatorname{CAR}(-5,-1)$ & $-0,68 \%$ & $1,83 \%$ \\
\hline & $\operatorname{CAR}(+2,+5)$ & $0,21 \%$ & $-2,74 \% * *$ \\
\hline & $\mathrm{CR}(0,+1)$ & $-1,46 \% * *$ & $4,54 \% * * *$ \\
\hline & CR $(-30,-1)$ & $-4,51 \% * *$ & $10,84 \% * * *$ \\
\hline \multirow{6}{*}{ Moeda } & $\operatorname{CAR}(0,+1)$ & $-0,14 \%$ & $0,79 \% * * *$ \\
\hline & $\operatorname{CAR}(-5,+5)$ & $-0,14 \%$ & $0,59 \% * *$ \\
\hline & $\operatorname{CAR}(-5,-1)$ & $-0,06 \%$ & $-0,01 \%$ \\
\hline & $\operatorname{CAR}(+2,+5)$ & $0,13 \%$ & $-0,22 \%$ \\
\hline & $\mathrm{CR}(0,+1)$ & $-0,15 \%$ & $0,96 \% * * *$ \\
\hline & $\mathrm{CR}(-30,-1)$ & $-0,21 \%$ & $2,78 \% * * *$ \\
\hline \multirow{6}{*}{ Bolsa } & $\operatorname{CAR}(0,+1)$ & $0,11 \%$ & $-0,29 \%$ \\
\hline & $\operatorname{CAR}(-5,+5)$ & $-1,21 \% *$ & $-2,71 \% * * *$ \\
\hline & $\operatorname{CAR}(-5,-1)$ & $-0,44 \%$ & $-0,95 \% * * *$ \\
\hline & $\operatorname{CAR}(+2,+5)$ & $-0,57 \% *$ & $-0,73 \% * *$ \\
\hline & $\mathrm{CR}(0,+1)$ & $0,24 \%$ & $-0,47 \% * *$ \\
\hline & CR $(-30,-1)$ & $1,16 \%$ & $-3,65 \% * * *$ \\
\hline
\end{tabular}

${ }^{*}$ signficante a $10 \%,{ }^{* *}$ significante a $5 \% \mathrm{e}^{* * *}$ signficantes a $1 \%$

Fonte: Autoria própria 
Tabela A.3 - Comparação da reação entre antes e depois de 2005 (com CAR)

\begin{tabular}{|c|c|c|c|c|c|}
\hline & & \multicolumn{2}{|c|}{ Antes de 2005} & \multicolumn{2}{|c|}{ Depois de 2005} \\
\hline & & up & down & up & down \\
\hline \multirow{6}{*}{ Moeda } & $\operatorname{CAR}(0,+1)$ & $-0,29 \% *$ & $1,64 \% * * *$ & $0,00 \%$ & $0,17 \%$ \\
\hline & $\operatorname{CAR}(-5,+5)$ & $-0,18 \%$ & $0,95 \% * *$ & $-0,06 \%$ & $0,29 \%$ \\
\hline & $\operatorname{CAR}(-5,-1)$ & $0,01 \%$ & $-0,33 \%$ & $-0,11 \%$ & $0,21 \%$ \\
\hline & $\operatorname{CAR}(+2,+5)$ & $0,17 \%$ & $-0,36 \% *$ & $0,10 \%$ & $-0,13 \%$ \\
\hline & $\mathrm{CR}(0,+1)$ & $-0,32 \% * *$ & $1,95 \% * * *$ & $0,01 \%$ & $0,22 \% * *$ \\
\hline & $\mathrm{CR}(-30,-1)$ & $-0,40 \%$ & $4,79 \% * * *$ & $-0,11 \%$ & $1,00 \% * * *$ \\
\hline \multirow{6}{*}{ Bolsa } & $\operatorname{CAR}(0,+1)$ & $0,33 \%$ & $0,27 \%$ & $-0,11 \%$ & $-0,63 \% * * *$ \\
\hline & $\operatorname{CAR}(-5,+5)$ & $-1,84 \% *$ & $-3,68 \% * * *$ & $-0,47 \%$ & $-1,96 \% * *$ \\
\hline & $\operatorname{CAR}(-5,-1)$ & $-0,68 \%$ & $-1,55 \% * *$ & $-0,15 \%$ & $-0,46 \%$ \\
\hline & $\operatorname{CAR}(+2,+5)$ & $-0,48 \%$ & $-0,66 \%$ & $-0,65 \%$ & $-0,78 \% *$ \\
\hline & $\mathrm{CR}(0,+1)$ & $0,46 \%$ & $-0,05 \%$ & $0,01 \%$ & $-0,69 \% * * *$ \\
\hline & $\mathrm{CR}(-30,-1)$ & $1,15 \%$ & $-6,87 \% * * *$ & $1,00 \%$ & $-0,75 \%$ \\
\hline
\end{tabular}

${ }^{*}$ signficante a $10 \%$, ${ }^{* *}$ significante a $5 \% \mathrm{e}^{* * *}$ signficantes a $1 \%$

Fonte: Autoria própria

Tabela A.4 - Resultados do modelo básico para a amostra após 2005 (com CAR)

\begin{tabular}{|c|c|c|c|}
\hline & & up & down \\
\hline \multirow{6}{*}{ CDS } & $\operatorname{CAR}(0,+1)$ & $-1,55 \% * *$ & $3,33 \% * * *$ \\
\hline & $\operatorname{CAR}(-5,+5)$ & $-0,99 \%$ & $-1,38 \%$ \\
\hline & $\operatorname{CAR}(-5,-1)$ & $-0,37 \%$ & $1,83 \%$ \\
\hline & $\operatorname{CAR}(+2,+5)$ & $0,20 \%$ & $-2,70 \% * *$ \\
\hline & $\mathrm{CR}(0,+1)$ & $-1,74 \% * *$ & $4,61 \% * * *$ \\
\hline & CR $(-30,-1)$ & $-3,18 \%$ & $9,57 \% * * *$ \\
\hline \multirow{6}{*}{ Moeda } & $\operatorname{CAR}(0,+1)$ & $0,00 \%$ & $0,17 \%$ \\
\hline & $\operatorname{CAR}(-5,+5)$ & $-0,06 \%$ & $0,29 \%$ \\
\hline & $\operatorname{CAR}(-5,-1)$ & $-0,11 \%$ & $0,21 \%$ \\
\hline & $\operatorname{CAR}(+2,+5)$ & $0,10 \%$ & $-0,13 \%$ \\
\hline & $\mathrm{CR}(0,+1)$ & $0,01 \%$ & $0,22 \% * *$ \\
\hline & CR $(-30,-1)$ & $-0,11 \%$ & $1,00 \% * * *$ \\
\hline \multirow{6}{*}{ Bolsa } & $\operatorname{CAR}(0,+1)$ & $-0,11 \%$ & $-0,63 \% * * *$ \\
\hline & $\operatorname{CAR}(-5,+5)$ & $-0,47 \%$ & $-1,96 \% * *$ \\
\hline & $\operatorname{CAR}(-5,-1)$ & $-0,15 \%$ & $-0,46 \%$ \\
\hline & $\operatorname{CAR}(+2,+5)$ & $-0,65 \%$ & $-0,78 \% *$ \\
\hline & $\mathrm{CR}(0,+1)$ & $0,01 \%$ & $-0,69 \% * * *$ \\
\hline & $C R(-30,-1)$ & $1,00 \%$ & $-0,75 \%$ \\
\hline
\end{tabular}

* signficante a $10 \%,{ }^{* *}$ significante a $5 \% \mathrm{e}^{* * *}$ signficantes a $1 \%$

Fonte: Autoria própria 
Tabela A.5 - Resultados do modelo utilizando o CDS como variável de controle (com CAR)

\begin{tabular}{|c|c|c|c|c|c|c|}
\hline & & \multicolumn{2}{|c|}{ Sem CDS como controle } & \multicolumn{3}{|c|}{ Com CDS como controle } \\
\hline & & up & down & up & down & CDS \\
\hline \multirow{6}{*}{ Moeda } & $\operatorname{CAR}(0,+1)$ & $0,00 \%$ & $0,17 \%$ & $0,08 \%$ & $-0,08 \%$ & $-0,04 \%$ \\
\hline & $\operatorname{CAR}(-5,+5)$ & $-0,06 \%$ & $0,29 \%$ & $0,38 \%$ & $0,02 \%$ & $-0,38 \%$ \\
\hline & $\operatorname{CAR}(-5,-1)$ & $-0,11 \%$ & $0,21 \%$ & $0,08 \%$ & $0,07 \%$ & $0,06 \%$ \\
\hline & $\operatorname{CAR}(+2,+5)$ & $0,10 \%$ & $-0,13 \%$ & $0,31 \% *$ & $0,01 \%$ & $-0,37 \% * * *$ \\
\hline & $\mathrm{CR}(0,+1)$ & $0,01 \%$ & $0,21 \% * *$ & $0,05 \%$ & $-0,08 \%$ & $0,13 \%$ \\
\hline & $\mathrm{CR}(-30,-1)$ & $-0,11 \%$ & $1,00 \% * * *$ & $-0,50 \%$ & $-0,36 \%$ & $2,69 \% * * *$ \\
\hline \multirow{6}{*}{ Bolsa } & $\operatorname{CAR}(0,+1)$ & $-0,11 \%$ & $-0,62 \% * * *$ & $-0,03 \%$ & $-0,48 \% *$ & $0,37 \% *$ \\
\hline & $\operatorname{CAR}(-5,+5)$ & $-0,47 \%$ & $-1,95 \% * *$ & $-2,01 \% * * *$ & $0,75 \%$ & $0,95 \%$ \\
\hline & $\operatorname{CAR}(-5,-1)$ & $-0,15 \%$ & $-0,46 \%$ & $-1,04 \% * *$ & $-0,21 \%$ & $0,02 \%$ \\
\hline & $\operatorname{CAR}(+2,+5)$ & $-0,65 \%$ & $-0,77 \% *$ & $-0,73 \% *$ & $0,81 \% *$ & $0,71 \% * *$ \\
\hline & $\mathrm{CR}(0,+1)$ & $0,01 \%$ & $-0,68 \% * * *$ & $0,09 \%$ & $-0,41 \%$ & $-0,11 \%$ \\
\hline & $\mathrm{CR}(-30,-1)$ & $1,00 \%$ & $-0,75 \%$ & $0,10 \%$ & $0,19 \%$ & $-7,25 \% * * *$ \\
\hline
\end{tabular}

* signficante a $10 \%,{ }^{* *}$ significante a $5 \% \mathrm{e}$ *** signficantes a $1 \%$

Fonte: Autoria própria 